\title{
Reconstruction of regional and national population using intermittent census-type data: the case of Portugal, 1527- 1864 \\ DOI:
}

10.1080/01615440.2019.1666762

\section{Document Version}

Accepted author manuscript

Link to publication record in Manchester Research Explorer

Citation for published version (APA):

Palma, N., Reis, J., \& Zhang, M. (2019). Reconstruction of regional and national population using intermittent census-type data: the case of Portugal, 1527-1864. Historical Methods.

https://doi.org/10.1080/01615440.2019.1666762

\section{Published in:}

Historical Methods

\section{Citing this paper}

Please note that where the full-text provided on Manchester Research Explorer is the Author Accepted Manuscript or Proof version this may differ from the final Published version. If citing, it is advised that you check and use the publisher's definitive version.

\section{General rights}

Copyright and moral rights for the publications made accessible in the Research Explorer are retained by the authors and/or other copyright owners and it is a condition of accessing publications that users recognise and abide by the legal requirements associated with these rights.

\section{Takedown policy}

If you believe that this document breaches copyright please refer to the University of Manchester's Takedown Procedures [http://man.ac.uk/04Y6Bo] or contact uml.scholarlycommunications@manchester.ac.uk providing relevant details, so we can investigate your claim.

\section{OPEN ACCESS}




\title{
RECONSTRUCTION OF REgIONAL AND NATIONAL Population using InTERmitTent CEnsus-TyPe Data: The Case of Portugal, 1527-1864 ${ }^{1}$
}

\author{
Nuno Palma (University of Manchester; Instituto de Ciências Sociais, \\ Universidade de Lisboa; CEPR) \\ Jaime Reis (Instituto de Ciências Sociais, Universidade de Lisboa) \\ Mengtian Zhang (London School of Economics)
}

\begin{abstract}
We offer a new methodology for the construction of annual population stocks over the very long run. Our method does not require the assumption of a closed economy, and can be used in situations in which local annual gross flows are obtainable. Combining gross flows with intermittent census-type data, it is possible to arrive at local, regional and national population stock estimates at annual frequencies. We provide an application to early modern and nineteenth century Portugal, using a large sample of parish-level statistics up to the first modern census of 1864. All six major regions of the country are considered.
\end{abstract}

\section{Forthcoming, Historical Methods}

Keywords: demographic reconstructions, early modern Portugal, nineteenth century Portugal

JEL codes: C65, J11, N33

\footnotetext{
${ }^{1}$ We are grateful to Cristina Giesteira, António C. Henriques, and Carlota Santos for providing us with access to their parish registers. We thank Remco Brandwacht, Oyumaa Daichinkhuu, Maria Ana Lopes da Fonseca, Filipe Alves Moreira, Paulo Paixão, Pedro Pinto, Frederico Santos, Cláudia Viana for dedicated research assistance. We also have a debt to António Oliveira, Margarida Sobral Neto, Enrique Llopis-Agelan, and the colleagues of the Prices, Wages and Rents in Portugal 1300-1910 project, which received financial support from Fundação para a Ciência e a Tecnologia. Nuno Palma also gratefully acknowledges funding from Fundação para a Ciência e a Tecnologia (CEECIND/04197/2017).
} 


\section{Introduction}

In this paper we use a new methodology which combines a limited supply of annual parish-level data for births and deaths with census-type data to arrive at annual regional and national population estimates. We use Portugal as our case study, but our methodology is more widely applicable. The period covered goes from 1527 to the first modern published census (1864). The standard of comparison in this genre is the justly famous reconstruction of England's population by Wrigley and Schofield (1989), whose estimates nonetheless suffer from two major disadvantages, as recognized by the authors themselves. Firstly, they lack any information regarding population stocks before the nineteenth century. This means that earlier population levels have to be inferred from parish-level information about flows combined with a mathematical technique known as back projection which relies on strong assumptions. Secondly, religious non-conformity (and a consequent lack of full national registration coverage) is an impeding factor in reaching satisfactory local estimates and hence regional and national ones (Wrigley and Schofield 1989, p. 4, 10). None of these problems has yet been rectified in their most recent attempts (Wrigley et al. 1997; Wrigley 2009).

We use Portugal as our case study for several reasons. One is the quality, homogeneity and abundance of its population data. This is the consequence of longterm political and institutional stability and of the consistent management of population records over centuries by a national institution - the Catholic Church enjoying a high degree of permanence and internal cohesion. This made it possible to avoid the large gaps in information at both the intra- and inter- parish levels of observation which beset the English case. It also helped in creating, at reasonable intervals, independent national benchmarks for population stocks which allow the construction of initial population levels directly, rather than having to infer them, as mentioned. Since both sources are available to a satisfactory degree from the sixteenth century, we are able to put together dependable national and regional series going as far back as that epoch. Interestingly, England's parish records used by WrigleySchofield estimates are widely considered to be the best available surviving records Deaton (2013, p.81) for instance, writes that "they provide by far the best record that we have for any country before about 1750". Wrigley and Schofield (1989, p. 2) themselves argue along the same lines. As we show here, this may not be entirely the case. 
Given the advantages of the approach we follow here and the relative scarcity of studies able to achieve comparable results, it may be worth considering whether our methodology is more widely applicable than simply to Portugal. There are two important requirements. One is that our procedure best serves countries with surviving parish-level data that are representative of the local populations. Another is the need for occasional, widely-spaced population counts undertaken under similar rules of execution and purpose. An additional recommended feature is long-run stability of borders, which ensures institutional and administrative homogeneity across the territory, but this, while simplifying the method considerably, is not compulsory.

Emigh et al. (2016) have debated the historical conditions that have shaped and stimulated census-taking over the last millennium in various countries. ${ }^{2}$ Bearing in mind their suggestions, countries with a history of strongly centralized institutions and intellectual elites seem better suited for our methodology. However, even for decentralized countries, our method can potentially be used at the regional level and subsequently aggregated into national figures. In Portugal, the situation is simpler because there was a centralized state which prevailed over the nobility. The Church, rather than a fiscal-revenues gathering elite (as in Italy), played a significant role in census-taking under the supervision of the state. ${ }^{3}$

The annual information we use comes, in part, from a large body of dispersed parishes previously gathered by other researchers and, for the rest, from new primary material especially collected for this purpose. The intermittent population counts that we also employ are well-known compilations from printed sources and have been closely scrutinized by different scholars for their quality. The desired annual levels of population, nationally and per region, as well as locally, are obtained by combining information regarding true stocks and parish-level flows, by means of a new methodology which also takes into account child mortality and emigration.

There are several motivations for carrying out the present exercise. One is that detailed, comprehensive demographic information is of interest to historians in its own

\footnotetext{
${ }^{2}$ See also Loveman (2014) for the case of Latin America.

${ }^{3}$ The hearth (fogo) was the unit consistently employed by parish priests to carry out their statistical duties under state supervision. Stability over time of hearths was emphasized by Fernando de Sousa, a pioneer in Portuguese demographic history - see Sousa (1979): "The counting of fogos by parish priests is a remote tradition in Portugal and constitutes no problem [for demographic history]” (p.67, our translation). See also Silveira (2001).
} 
right. ${ }^{4}$ Another is that it can be a critical tool in all kinds of social and economic analytics, allowing, for example, the detailed scrutiny of Malthusian hypotheses. ${ }^{5} \mathrm{~A}$ third is that in Portugal (and in many other countries) there are enormous gaps between the few data points for which there is trustworthy information about the population stock. Hence, to draw a population curve by simply linearly interpolating between them, as is often done, does not produce sufficient identifying variation for the series to be usable in statistical analysis. Finally, it makes it possible, for the first time, to recognize and account for variations in the regional long term patterns of Portugal's demography. This will enable us, for example, to complement the analysis in Palma and Reis (2019), where the broader macroeconomic facts of Portugal's history are described and the population data produced here is an input. ${ }^{6}$ We show that the Malthusian model does not apply well to long stretches of Portugal's early modern history, even though "from a very long perspective it stands true that Portugal's per capita real income was no higher in 1850 than it had been in the early 1530s" (Palma and Reis 2019, p. 498).

During nearly all of the period considered, Portugal was divided into six provinces for administrative, judicial and political reasons and we will follow here this tradition too. They are: Entre-Douro-e-Minho, Trás-os-Montes, Beira (sometimes divided into Beira Interior and Beira Litoral), Estremadura, Alentejo (also known as Entre-Tejo-e-Odiana) and Algarve. ${ }^{7}$ These units were created not only for important practical purposes - particularly administrative and military - but came to be generally regarded as having their own persistent cultural and economic identities, even after their abolition in $1832 .^{8}$

At a glance, there was considerable variation across these regions in terms of size, density and degree of urbanization. The north of the country was always more populous than the south and this difference increased steadily from the sixteenth to the

\footnotetext{
4 When reporting Portugal's early modern population, Maddison (2006, p. 230) simply assumed that it grew in parallel to the population of the total of 12 large countries.

${ }^{5}$ Such studies typically require annual data, which is one reason why they are almost always done using English data. For an exception (which relies on vital rates, not stocks), see Fernihough (2013); see also Chiarini (2010). Population studies for countries other than England are usually based on benchmarks at non-annual frequencies or rely on strong assumptions to obtain annual data; they typically start no earlier than the late sixteenth century; see Pfister and Fertig (2010), Del Panta and Livi Bacci (1980), Dupâquier (1980), Edvinsson (2015), Galloway (1988, 1994).

${ }^{6}$ For a pioneering effort of this kind which links demographic patterns with political and institutional circumstances, see Hespanha (1994).

${ }^{7}$ Figure 1 below shows the outlines of these various provinces.

${ }^{8}$ See Hespanha (2010) and Oliveira (2015).
} 
nineteenth centuries, as happened also, of course, with their respective densities. By contrast, the south was always more urbanized (Matos and Marques 2002). ${ }^{9}$ Population grew briskly during the period under consideration. Total inhabitants rose from around 1.130 million in 1527 , the earliest national figure available, to 3.830 million in 1864, our terminal point. This implied an increase in population density from 14.7 to 43.0 residents per square $\mathrm{km}$, both of which figures are close to the European norm of the times, that is, respectively 14.0 and 49.6 (Malanima 2009).

We confine our efforts here to mainland Portugal. The significant variance in the social and economic characteristics of the overseas territories under its rule indeed renders this highly advisable. It means we ignore current research on locations such as the Atlantic islands of Madeira and the Azores, and the far-flung land mass which comprised the vastness of the Portuguese Empire in Asia, Africa and America prior to the early nineteenth century. ${ }^{10}$

\section{The data}

As noted previously, our study rests on two types of data. Its cornerstone is a set of population counts which were assembled at irregular intervals on a national scale, on the basis of information obtained at the lowest level of public administration, the parish. ${ }^{11}$ The second consists of a country-wide sample of demographic flows constructed from the birth and death registers of its parishes and covering different time spans according to data availability.

\subsection{Population stocks}

Population counts, whether local, regional or national, were numerous in this period. This should be no surprise since although still largely in the pre-statistical era $^{12}$, Portugal had long displayed clear traces of a quantitative mentality, as indeed happened in much of contemporary Europe (Emigh 2002). It had also shown a considerable capacity for data organization at all levels of administration and for all

\footnotetext{
9 The south was led by Lisbon, a metropolis on a European scale: by the late eighteenth century it was the fourth city in Europe (Bairoch 1976).

${ }_{10}$ Work on the demographic history of the Azores and Madeira archipelagos has been carried out by Amorim (1992 and 1999) and Santos and Matos (2013). On the empire, see Matos (2016).

${ }^{11}$ Of the six counts we shall be using here, only the so-called Numeramento da População de 1527-32 did not refer to parishes but instead to municipalities, villages, hamlets and "places".

12 We assume the transition from the pre-statistical to the statistical era occurred gradually from about 1750 (King et al 2000). By contrast, the Institute of International History suggests something closer to 1914 as the turning point. See https://iisg.amsterdam/en/research/projects/hpw.
} 
sorts of purposes (Rodrigues 2008, pp. 139-57). ${ }^{13}$ The 18th century, in particular, witnessed six major efforts of this sort (Serrão 1993; Chorão 1987). As a rule, they were responses to specific needs of government - financial, military, religious, and, less often, administrative. ${ }^{14}$ Their degree of success, naturally, was variable. The quality of the results, however, can be thought of as being quite good, as might be expected of a country which in the eighteenth century had a numeracy rate close to that of the most advanced countries in Europe (Stolz et al. 2013, pp. 562-4). They have been used extensively by historians to analyse the long term evolution of Portugal's demography. It is out of this pool of possibilities that we have selected the six population enumerations on which the construction of our population series will be founded. They correspond to the years 1530, 1700, 1758, 1801, 1849, and 1864 .

Table 1 provides a comprehensive view of the current state of knowledge in this respect. It comprises a heterogeneous collection which displays our preferred stocks alongside the better-known and the more influential guesstimates by historians. Although most items do not meet our standards of accuracy, we find it useful to show them here for the sake of comparison with our own results.

\begin{tabular}{c|c|c|c}
\hline Year & Population $(\mathrm{m})$ & Estimate type & Source \\
\hline 1500 & 1.00 & Historians' guesstimate & Rodrigues (2008, p.176) \\
1530 & 1.13 & $\begin{array}{c}\text { Hearth count } \\
\text { (numeramento }) \\
\text { Historians' guesstimate }\end{array}$ & Dias (1998, p.16) \\
1580 & 1.2 & Rodrigues (2008, p.176) \\
1639 & 1.35 & Historians' guesstimate & Magalhães (1988, p. 22) \\
1640 & $1.4-1.5$ & Historians' guesstimate & Serrão (1975) \\
1695 & 2.05 & Historians' guesstimate & Pinto et al (2001, p. 395) \\
1700 & 2.10 & Historians' guesstimate & Godinho (1980, p.19) \\
$1706-12$ & 2.35 & Corografia & Rodrigues (2008, p. 253)
\end{tabular}

\footnotetext{
${ }_{13}$ Already by the mid seventeenth century, Portugal possessed a thoroughly established universal income tax - the Décima Militar - which exempted the nobiity and the clergy but allowed few others to escape its clutches. See Reis (2017).

14 An interesting case is the count (numeramento) of 1527-32. The crown based on its results the sweeping administrative reform which brought into existence soon after the country's division into provinces and the abolition of the old comarcas of the fourteenth century.
} 


\begin{tabular}{|c|c|c|c|}
\hline 1729 & 2.64 & Historians' guesstimate & Magalhães (1988) \\
\hline 1732 & 2.14 & Historians' guesstimate & Godinho (1955, p. 302) \\
\hline 1750 & 2.36 & Historians' guesstimate & Pinto et al (2001) \\
\hline 1758 & 2.53 & $\begin{array}{c}\text { National survey } \\
\text { of parishes }\end{array}$ & Magalhães (1988, p. 28) \\
\hline 1768 & 2.41 & Historians' guesstimate & Godinho (1955, p. 302) \\
\hline 1798 & 2.97 & Military census & Serrão (1970) \\
\hline 1801 & 2.89 & Census & Silveira et al (2001) \\
\hline 1819 & 3.01 & Historians' guesstimate & Matos and Marques (2002) \\
\hline 1835 & 3.06 & Historians' guesstimate & Rodrigues (2008, p. 331) \\
\hline 1849 & 3.41 & Census & Silveira et al (2001) \\
\hline 1864 & 3.83 & $\begin{array}{l}\text { First modern published } \\
\text { census }\end{array}$ & $\begin{array}{l}\text { Estatística de Portugal } \\
\qquad(1868)\end{array}$ \\
\hline
\end{tabular}

Table 1. Benchmark national population stocks.

Our choice of population stocks is based on a number of characteristics which they have in common and which are highly relevant because of their positive effect on the robustness of the estimation. The first is the fact that they were carried out by a central agency - the state, the church or a combination of the two. The exception was the Corografia (1706-12) ${ }^{15}$, which, as we shall see, displays nevertheless an adequate capacity for this implementation. In every case, these counts were carried out according to standard, uniform procedures and a universal plan, thus ensuring an appreciable uniformity in our results.

The second feature is that in every case complete coverage was one of the chief goals. As a result, we may trace any parish in our sample to any benchmark year so that neither national nor regional totals are distorted by omissions on this account. The third is that the objectives pursued by these counts tended to be general-purpose in nature, rather than subject-specific. Essentially they focused on the size and distribution of the population, not on other less appealing objectives (from the population's point of view) such as recruitment or fiscal needs. Popular resistance to these enquiries and its nefarious impact on data reliability can be assumed to have been on a lesser scale and would have induced less bias.

\footnotetext{
${ }^{15}$ In the case of the Corografia, the author was a single, private author. He employed, however, a large number of helpers in the provinces and must have had a plan, given the uniform nature of his many local descriptions. Costa, the compiler, reports having made several trips around the country to check his facts.
} 
The fourth aspect to consider is the stability of the units under observation. From the sixteenth to the nineteenth centuries, the size and configuration of Portuguese parishes rarely changed. Only a few were broken into smaller units, and those that were extinguished were even less common (Hespanha 1994). ${ }^{16}$ Practically all the localities in our sample can therefore be tracked for more than three hundred years since the early sixteenth century without risk of reductions or augmentations in population being the artificial result of administrative changes.

A brief synopsis of these six essential tools will make the above points clearer. The earliest of them, commonly known as the Numeramento da População, was ordered by King John III and was the first ever national census in Portugal. ${ }^{17}$ Its stated aim was simply to know "how many ... live in the cities, towns and places of the realm" (our translation). It took from 1527 to $1532^{18}$ to complete owing to resistance on the part of lay and clerical lords who refused the census-takers' entry into to their lands. Data from it are irretrievably lost for the city of Lisbon and the province of Algarve. Like all population counts prior to 1801, its result is given in hearths (fogos) rather than inabitants; and parishes, unusually, were not the territorial unit of reference. ${ }^{19}$

The second count, commonly known as the Corografia, came almost two hundred years later. It is found amidst the pages of the three-volume Corography of the Kingdom of Portugal. This was an immense repository of miscellaneous information regarding the country's geography, history, orography and hydrography, as well as the genealogies of the country's notables, the nobility of the principal buildings, the distances between localities, and the intricacy of jurisdictions, taxes and feudal dues (Costa 1706-1712). Significantly for us, it contains a reckoning of the hearths in each one of the vast majority of the country's parishes. Given some

\footnotetext{
${ }_{16}$ As can be seen from the data appendix, by 1500 most of these parishes were already two or three hundred years old and thus evinced a high degree of persistence. This picture changed only with the arrival of the Liberal state in the first half of the nineteenth century. Many borders were then re-drawn and many parishes were either divided or absorbed into other ones. See Silveira et al. (2001).

17 The printed sources for this count are Colaço (1934) and Freire ([1903-16] 2001). Valuable historiographic analysis of this fundamental document is found in Dias (1996) and Rodrigues (2008).

${ }_{18}$ Owing to the need for a single year for dating its output, we have chosen to ascribe its values to the mid-point year of the quinquenium, i.e. 1530.

19 Of the three instruments used for counting population in Portugal during the early modern period fogos, vizinhos and moradores - fogos, which we adopt here, are the most appropriate. They consisted of a co-resident task-oriented domestic group plus servants, who shared the same residential physical space (Szoltysek 2015). Unlike vizinhos, they were not subject to exclusion from national or regional counts on grounds of, for instance, length of residence or marriage requirements. When the head of a family was widowed, a fogo might become known as a half-hearth (meio fogo) in some references, but we have not come across this in any of the censuses we used. For a detailed discussion, see Cosme (2017) and Dias (1996). On the advantages of using the "hogar" (hearth) in Spanish demographic methodological history, see Reher (1988).
} 
uncertainty about dating the collection of this evidence, we have assumed it corresponds to the year 1700, following Silva (2001)'s suggestion. Its author, António Carvalho da Costa (1650-1715) was a cleric and a distinguished astronomer who spent many years on this book, travelling extensively around the country to check his sources and enlisting the help of numerous local correspondents. Although criticised by many, it soon became a work of reference and a model for subsequent corographies and descriptions of eighteenth century Portugal. ${ }^{20}$

Our third source has the familiar designation of Memórias Paroquiais and was started and completed in 1758. ${ }^{21}$ Local enquiries were carried out, on the orders of Pombal (the king' first minister), by the clergy in the 4,123 parishes then in existence. The aim was to secure detailed knowledge of the country's geographic, demographic, orographic, hydrographic, historical, economic and administrative affairs. The exercise was organized according to a plan containing a total of sixty written questions (Rodrigues 2008, Silbert 1966). The main difference vis-à-vis the Numeramento and the Corografia is that the Memórias generally quantified population by the number of hearths but at times counted also inhabitants. These were divided into adults; children under 7; and children between 7 and 14 years of age. ${ }^{22}$ Since these categories were used erratically, however, it is not advisable, when employing this tool, to use anything but hearths.

The shift into the nineteenth century accelerated census-taking and changed its character significantly by gradually professionalizing this activity (Sousa 1995). During the next sixty-four years, our three last reliable population counts took place in 1801, 1849 and 1864 - the last of them having been the first one ever to be published in Portugal. The purpose by now was simplified to merely creating a demographic record, albeit a much more complex one than before, including features like gender, age and civil status. The most important innovation from the point of view of the present study was the switch to the systematic counting of individuals,

\footnotetext{
${ }^{20}$ For recent scholarlship both for and against this monumental work, see Hespanha (1994) and Santos (2003), respectively. For an excellent introduction, see Silva (2001) in the digitalized version available at http://www.cidehusdigital.uevora.pt/ophir-restaurada/corografia

${ }_{21}$ The manuscript Memórias Paroquiais have been preserved in full at the National Archives and can be accessed electronically and cartographically at atlas.fcsh.unl.pt/cartoweb35/atlas/apresentacao.html. A considerable part of them are in print: most of the erstwhile provinces of Entre-Douro-e-Minho, Trásos-Montes, Beira and Alentejo. A predecessor publication of 1747-1752 covered only parishes with names starting with the letters A to C.

22 For a careful explanation of how and why these groups were established, see Oliveira (2002). For a juridical rather than a religious approach to the construction of these age categories, see Hespanha (2010).
} 
although hearths still continued to be in use. At the same time, the fundamental unit of observation continued to be the parish, thus allowing us to carry on our series safely through to 1864 without loss of consistence.

Although our set of six national population counts provides a sturdy framework for the present study, some flaws have to be recognized and assessed. Two are especially important. One is the heterogeneity of how population is counted hearths versus individuals - which makes it difficult to link raw data from before and after 1800. The other arises from the fact that despite the good overall coverage of these counts, over time gaps might arise in some parishes and this could have affected their results.

In the first case, the question is whether the conversion factor, in other words, the national hearth mean size (HMS) - which transforms hearths into population tallies - can be clearly determined for the long run. Indubitably, a degree of fluctuation over time will have existed as a result of short-term local influences but how significant would this be in a broad view? Table 2 displays a considerable number of these ratios at the national level. They are obtained from the specialized demographic literature for the period before 1800, and afterwards, from the three succeeding official censuses of the nineteenth-century.

Two aspects of this compilation must be noted. The most important is the prevalence, throughout, of a ratio of 4.0 or thereabouts, and the absence of signs of a time trend which could lead to a bias in our estimates. Doubts may arise as to whether this lengthy persistence is warranted. We deal with this in two ways. First, we carry out a robustness test with three estimates for the Portuguese population being based on mean hearth sizes between 3.5 and 4.5 during the period 1527-1800. For the remaining years a common conversion ratio of 4.0 is used since no assumptions are needed for the nineteenth century. ${ }^{23}$ Second, we seek corroboration in other contemporary experiences. Although evidence is not abundant, two instances show that prolonged stability is not entirely far-fetched. One is the case of England and Wales, where between the sixteenth century and 1911, the mean household size "was relatively constant at 4.75 or a little below" (Laslett 1969). ${ }^{24}$ Another is the European

\footnotetext{
${ }^{23}$ The results for the robustness exercise are in the Appendix. The best estimates come from the period 1801-1864. They were calculated using what for then were state-of-the-art procedures and were based on the largest sample possible.

${ }^{24}$ The difference between the English/Welsh and the Portuguese ratios may be due to the fact that the former refers to households and the former to hearths.
} 
overview by Mols (1966), according to which 4.0 was the most common ratio in Europe during the early modern period. ${ }^{25}$

\begin{tabular}{|c|c|c|c|}
\hline Date & Ratio & Type of estimate & Source \\
\hline $1540 s$ & 4.1 & Guesstimate & Dias (1996) \\
\hline $16^{\text {th }} \mathrm{c}$. & $4.3-4.8$ & Guesstimate & Dias (1996) \\
\hline $16^{\text {th }} \mathrm{c}$. & 4.6 & Guesstimate & Dias (1998, p. 16) \\
\hline $17^{\text {th }} c$. & $3.5-4.0$ & Guesstimate & Santos (2003) \\
\hline $17^{\text {th }} \mathrm{c}$. & 4.0 & Guesstimate & Godinho (1980), Magalhães (1988) \\
\hline $18^{\text {th }} \mathrm{c}$. & 4.0 & Guesstimate & Oliveira (2002) \\
\hline 1798 & 4.0 & Military census & Serrão (1970, 1995) \\
\hline 1801 & 3.9 & Census count & Census 1801 (Silveira 2001) \\
\hline early $19^{\text {th }} c$. & 4.0 & Guesstimate & Silbert (1966) \\
\hline 1849 & 3.9 & Census count & Census 1801 (Silveira 2001) \\
\hline 1864 & 4.0 & Census count & Census 1864 (Estastíca de Portugal 1868) \\
\hline
\end{tabular}

Table 2. National hearth mean size (HMS), $16^{\text {th }}-19^{\text {th }}$ centuries.

A second kind of flaw was the possibility of gaps or serious errors in the reported population stock of particular parishes. If these were to be at all frequent this could seriously undermine the robustness of our methodology. They could arise for a variety of reasons. Parish priests, who were the "statistical agents" employed by the state at this time to count its subjects, were not unknown to simply omit the required information. Moreover, although a cultural elite in the countryside, priests could sometimes administer parish records carelessly and make mistakes. Thirdly, for the historian, small, ancient and obscurely-named parishes can be hard to trace across time and identify in the population counts. ${ }^{26}$

The impact of these shortcomings was not negligible but turned out less problematic than one might have supposed. One reason is that in many such situations it has been possible to resort to other primary sources, of a regional but similar nature, and replace the missing or distorted evidence with their help. The replacement data may not coincide chronologically with the gaps in the stocks but are close enough to effect the compensation and save us from distorting our conclusions. ${ }^{27}$ We rely on such

25 This result is very similar to Spanish ratios. See Drelichman and Gonzalez-Agudo (2014) and Calderón-Fernández et al (2017). For the French case, Dupaquier (1988, p. 54-55) insists that 4.0 is the correct ratio.

${ }_{26}$ This arises particularly in the case of the Numeramento da População statistics of 1527-32.

27 The appendix Figure AA1 and Tables A1 and A2 summarize to what extent the 71 localities of this study needed corrections of this sort and how well these substitutions functioned. 
proxies, for instance, in the few cases for which we are unsure about the exact geographic reach of a place, as there could have been an administrative boundary change at a later date. ${ }^{28}$ The substitutions we have made are entirely concentrated in the initial three national population stocks - those which relate to 1530,1700 and $1758 .^{29}$ For the period prior to 1801 , gaps in the known stocks were not trivial, but we were almost always able to resort to additional lesser population counts. These enabled us to bring down "effective gaps" from $30 \%$ to a reasonable $11 \%$ per cent of total counts (table 3 ).

\begin{tabular}{ccc}
\hline & Number & share of total counts \\
\hline Total effective counts & 150 & 0.70 \\
\hline Total gaps: & 63 & 0.30 \\
$\begin{array}{c}\text { replacements } \\
\text { residual gaps }\end{array}$ & 40 & 0.19 \\
$\mathbf{N}=\mathbf{2 1 3}$ & 23 & 0.11 \\
\hline
\end{tabular}

Table 3. Summary of gaps and replacements made. ${ }^{30}$

\subsection{Gross flows}

Gross demographic flows are the raw material which allows us to transform the intermittent evidence from our stock counts into estimates of total annual population. Altogether, we use information from seventy one parishes, the geographic location of which is shown in Figure $1 .{ }^{31}$ They vary considerably in size, from quite small, especially in the earlier years in which some have less than one hundred individuals, to large ones, with several thousand parishioners. While we do not have data on the country's biggest cities - Lisbon and Porto ${ }^{32}$ - just as Wrigley and

\footnotetext{
${ }_{28}$ Table A1 in the online appendix maps these gaps over the entire period under consideration and shows the replacements which we made.

29 The last three counts (shown as cols. 9, 10 and 11 of Table A1 in the online appendix), as expected, were free from irregularities of this sort and were the main cause for the remarkably high overall average of counts per parish (col.12). Part I of Silveira et al (2001, vol.1) demonstrates the technical superiority of the 1801 and 1849 censuses.

${ }^{30}$ See Table A 1 of the appendix for details (in particular, cols. 1 to 8 ).

${ }^{31}$ Out of a total of about 4,100 in 1801 (Silveira 1801). From the late sixteenth century onward our sample always corresponds to a significant percentage of the total population: in $1590,1.8 \%$, in 1700 , $2.3 \%$, in $1801,1.8 \%$; and in $1849,1.9 \%$.

32 Studies of single parishes in Lisbon are scarce and very partial. The Sé (Godinho 2007), and the Mercês and Santa Catarina parishes (Neto 1959, 1967) are hardly representative of the roughly fifty
} 
Schofield (1989) do not have on London - we have data for several major urban centers such as Aveiro, Coimbra, Évora, Póvoa de Varzim, Vila do Conde and Viseu. As might be expected, more data survive for later periods, and the surviving data for most of our parishes do not cover our entire period. In the majority of our cases, the data only start after the sixteenth century.

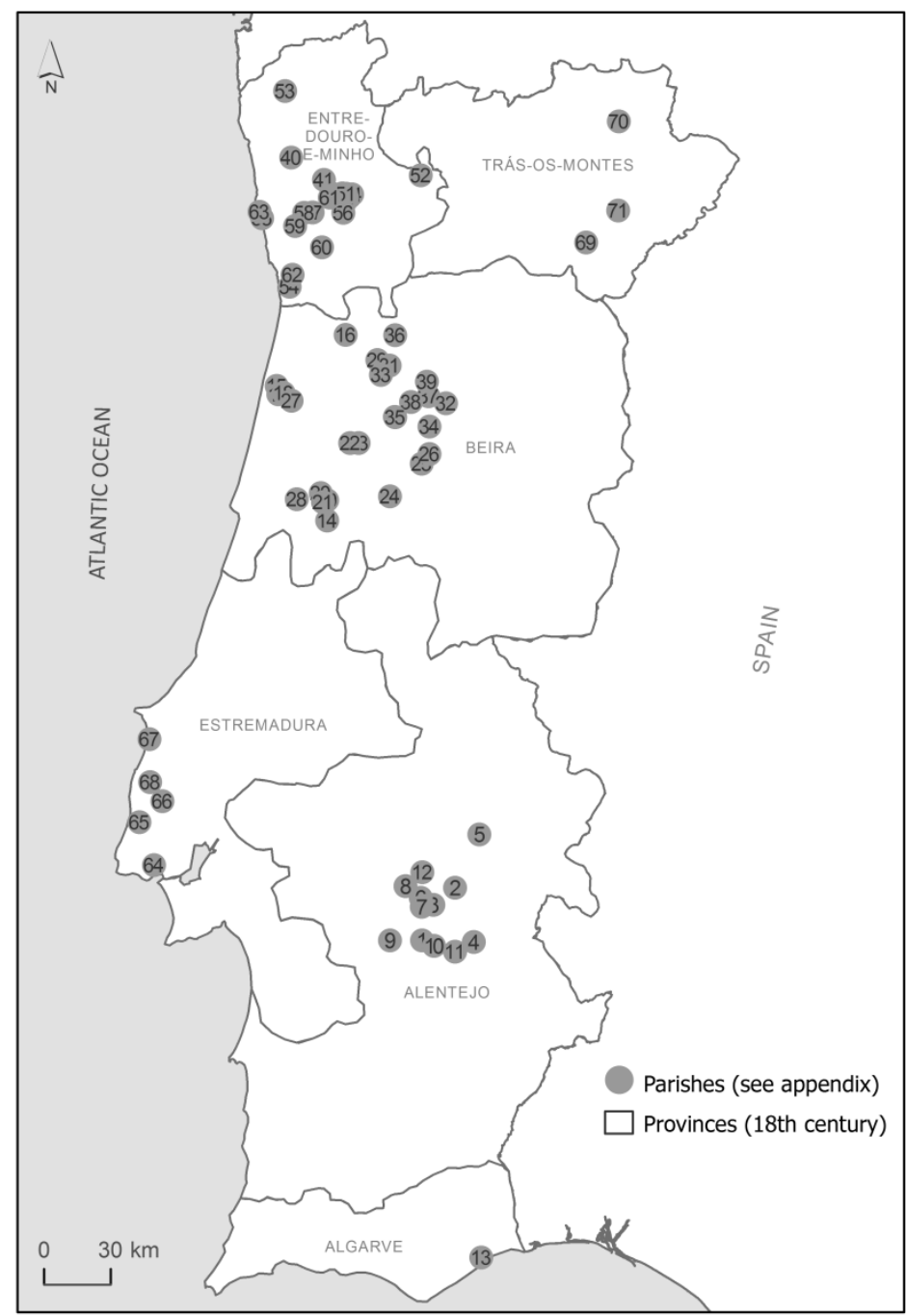

Figure 1. Location of parishes in our sample. For the list of parishes, see table A3 of the Appendix. Sources: For the provincial boundaries, which refer to the $18^{\text {th }}$ century, see Marques and Dias (2003). For the location of the parishes, we used Project Historical Atlas, available at: http://atlas.fcsh.unl.pt/cartoweb35/atlas.php?lang=pt

Gross flows are simply count data of the number of births and deaths that are registered in a given year as having occurred in a certain parish. To produce them we have used information from all the available secondary sources that to our knowledge

parishes which comprised the entire city. For Porto, Osswald (2008) studies births and deaths in the seventeenth century but does not supply any raw data of the kind needed for our present anaylsis. 
exist, and have further filled in gaps by collecting additional primary source material ourselves, for regions and time periods for which we deemed the existing ones inadequate. ${ }^{33}$ The online appendix to this paper furnishes the entire list of parish-level sources used to obtain the data.

\section{The methodology}

Our numbers do not rely on either the back projection method (Wrigley Schofield 1989) or the inverse projection method (Lee 1974, 1985). ${ }^{34}$ An important advantage of our method is that we do not need to know the age distribution of the population at any point in time. Not having to worry about mortality rates for each age group implies that our method requires considerably less historical information and is simpler to implement than those methods. At the same time, our method is designed to account for measurement error introduced by child mortality being underreported in parish data flows, and it does not require the assumption of zero net migration - the latter being an important disadvange of the inverse projection method (Wrigley and Schofield 1989, pp. 7-8, 194).

While our aggregate annual estimates go as far back as 1530, it is important to realize that at different times the relative weight of the evidence varies. As usual, the evidence is thinnest for the periods further back; for the first half of the sixteenth century all the evidence we have comes from just five parishes - Bobadela, Lagares, Enxara do Bispo, Lourinhã and Vila do Conde. In later periods, data becomes much more abundant. ${ }^{35}$ Our total of seventy one parishes forms an unbalanced panel but many of them go from the sixteenth to the nineteenth century. ${ }^{36}$

In our data set, all stocks (e.g. population levels) refer to beginning-of-period quantities, while flows, e.g. births, correspondingly refer to quantities which apply to the duration of the year in question. In a few, rare cases we had to make assumptions

\footnotetext{
${ }^{33}$ In the case of several secondary sources, their authors only present the data in graph form without showing the raw data in tabular form. In one of them, only three year averages are given. See Amorim (1983-4). Obviously both cases are of no use to us. At times, we decided not to use a parish because the coverage was too short or too far from the periods for which "preferred" stocks are known. For $S$. Martinho da Árvore, for example, we have benchmarks for 1530 and 1700 and therefore cannot employ it because the only available flow covers 1616-1685.

${ }^{34}$ Back projections and inverse projections are special cases of a wider class of models (Oeppen 1993).

35 Almalaguez (today called Almalaguês, near Coimbra) has continuous data from 1560-1864. The exact coverage dates for each parish are given in the online Appendix.

${ }^{36}$ For the much bigger country that England was, the standard study aggregates the contents of 404 parish registers for a period of 330 years, many of which are incomplete (Wrigley, and Schofield 1989).
} 
about missing data, ${ }^{37}$ but in calculating the regional estimates there are no interpolations; all data correspond to observed annual variation.

\subsection{Why is a correction needed for the data?}

Starting with any given stock, simply summing up gross flows (i.e. reported births minus deaths) over time would lead to a biased estimate of population stocks at any given moment. This becomes noticeable by the time that the next stock is observable. The reason for the bias (usually leading to an overestimate) is that measured net births do not account for two important factors which affect true net flows: migration and unrecorded child mortality. ${ }^{38}$ Since we are mostly considering rural areas in this study, in practice migration numbers were almost always positive in net terms, leading to a negative non-observable flow (i.e. gross flows were larger than net flows). ${ }^{39}$ Since the true value of population is known at intervals, however, it is possible to partially correct for such biases by adjusting the residual.

\subsection{Net flows}

As discussed in the previous subsection, it is necessary to make corrections to the gross population flows, namely with respect to non-observable flows that need to be accounted for. The mapping of the number of baptisms and burials contained in the parish registers into actual births and deaths is no simple matter; Wrigley and Schofield (1989) spend several chapters describing their methodology. Here we can afford to be more parsimonious as the superior features of the Portuguese data allow for simpler - and more credible - mathematical calculations. ${ }^{40}$ The anchoring provided by the 1527-32 Numeramento da População allows us to make sure that no systematic cumulative errors occur as we move back in time. This is a matter of serious concern in the English case, which, due to lack of alternative options, either takes as a maintained assumption that no net migration was taking place (inverse

\footnotetext{
${ }^{37}$ We used a five-year moving average for the single missing cells and eight years for longer periods.

${ }^{38}$ Unrecorded child mortality corresponds to children who died before they were 7 years old and then were not recorded by the parish priest as dead, though they had been recorded at birth. These deaths are sometimes known to us, but more often than not they are not, which requires an adjustment. 39 The danger of simply calculating stocks backwards using flows can be illustrated by the fact that for several parishes such a naïve adjustment would lead to negative population stocks by the early seventeenth century. Even for those for which such clear nonsense does not occur, the values are usually too low compared with those of the Numeramento da População of 1527-1532.

${ }^{40}$ Since a few pre-1800 stocks are available, and because sample selection is much less of an issue than in England, our estimates for Portugal rely on much weaker assumptions - hence allowing for more credible conclusions.
} 
projections), or makes strong assumptions with regards to migration and the mortality levels (back projections; Wrigley and Schofield 1989, pp. 194-5, 72 1-730).

In the case of our estimates, one option would be simply to assume that the residual is uniform across the board between benchmarks. Instead, we explicitly consider which items compromise those non-observables. The first and principal source of under-registration in deaths, as mentioned, is of children who were less than 7 years of age and whose absence from the death register was due to their not having yet been admitted to any sacrament. They were thus present in the birth register but omitted from the death records. ${ }^{41}$ The second source of under-registration was migration. We will now consider each in turn.

We estimate the true number of deaths as the total of recorded deaths plus the number of deaths up to the age of 7 . For the few cases in which this information is available, we use it. For the rest, we estimate deaths under the age of 7 in accordance with the distribution for a period for which this is known in detail (Table 4). ${ }^{42}$

\begin{tabular}{cc}
\hline & Percentage of deaths \\
\hline$<1$ year & 16.3 \\
$\mathbf{1}$ to 4 years & 14.0 \\
years 4 to 6 & 2.30 \\
died $<$ 7 total & 32.6 \\
\hline
\end{tabular}

Table 4. Mortality distribution by classes of age born in Urgeses (Guimarães), 1793-1819. Source: Amorim (1987, p. 276).

Table A1 in the Appendix shows other locations for which we know child mortality until age 7, albeit with less detail in terms of age breakdown as Table 4. However, Table A1 confirms that the numbers of Table 4 are credible.

A separate, less important but related issue concerns the underestimation of births. Under-registration of births happens when the child died before receiving baptism (Santos 2003, p. 164-5). Baptisms occur immediately or shortly after birth since in accordance with Christian beliefs this would save the child's soul from original sin should death occur early on. While this was the twentieth-century practice, for earlier periods transportation difficulties were more of an issue. We know that at least for one region, 3\% of children died before baptism (Alves 1986, p. 135). For most

\footnotetext{
${ }^{41}$ The issue here is that while recorded births correspond to baptisms, the death of young children was not recorded since they had not reached the age of confession and anointing of the sick and so their death could not be certified by the priest. See Santos (2003, pp. 164-5), Oliveira (1990, 2002), Miranda (1993) and Amorim (1987).

42 Additionally, unspecified measurement errors are also surely present at times. In practice this will be bundled here with the migration part of the residual. In the cases where the parish registers include child mortality, we make no adjustments, as none is needed.
} 
regions quantitative data is lacking, but we do know that at least some newborns who died before baptism were not registered (Santos 2003, p. 165.) We have no way of knowing how representative these pieces of evidence are, and the first one certainly seems a bit high by comparison with widespread Christian practices; indeed, social norms forced baptism to happen within a week of birth (Costa 1994).

All considered and except where we have definite evidence to the contrary, we assume all births were registered. We therefore make a correction to deaths only. What is important to realize here is that unlike with the underestimation of deaths, here the total flows are correct since the newborns that died before baptism were not recorded at all, and hence do not appear in our measure of either births or deaths.

A final issue concerns emigration, about which we have no direct information. ${ }^{43}$ Census and census-type information about stocks serve as checks which anchor the estimated quantities based on flows. We estimate unobserved emigration flows residually as the difference between the observed population stock at the end of a period and the estimate which would be given by sequentially adding the difference between births and corrected deaths. For instance, we know that 10,465 people lived in the city of Guimarães in 1700. If we then repeatedly add corrected net population growth to this number, we obtain 13,755 inhabitants in 1758. However, the censustype data we have for that year reveals only 8,066 people lived there at this date. The difference presumably corresponds to net outflows due to migratory movements, including emigration, the latter in particular during the period of the gold rush to Brazil during the eighteenth century. ${ }^{44}$ When possible, we cross-check that the result is broadly in line with the masculinity ratio - the ratio of men to women at a given moment - since it is always young men who emigrate disproportionately . In Figure 2 we show an exemple of the resulting correction we have made to deaths.

In some instances, information about births is available much earlier than that about deaths. When information about deaths is missing for just a few years, we proxy it by using a moving average; but in most cases, we simply ignore this information and start the series when both are available. Even in the absence of analogous information about deaths, earlier information about births still presents useful information on the Malthusian preventive check - which was more important than the positive check, at least in a European context (Nicolini 2007) - but that is beyond the scope of our paper.

\footnotetext{
${ }^{43}$ For general views but sparse information, see Godinho (1978), Magalhães (1988) and Livi Bacci (2002).

${ }_{44}$ By the eighteenth century, the empire was having a non-negligible effect on the mother economy; Costa et al (2015) estimate that in the heyday of colonial expansion, eliminating the economic links to empire would have reduced Portugal's per capita income by at least a fifth.
} 


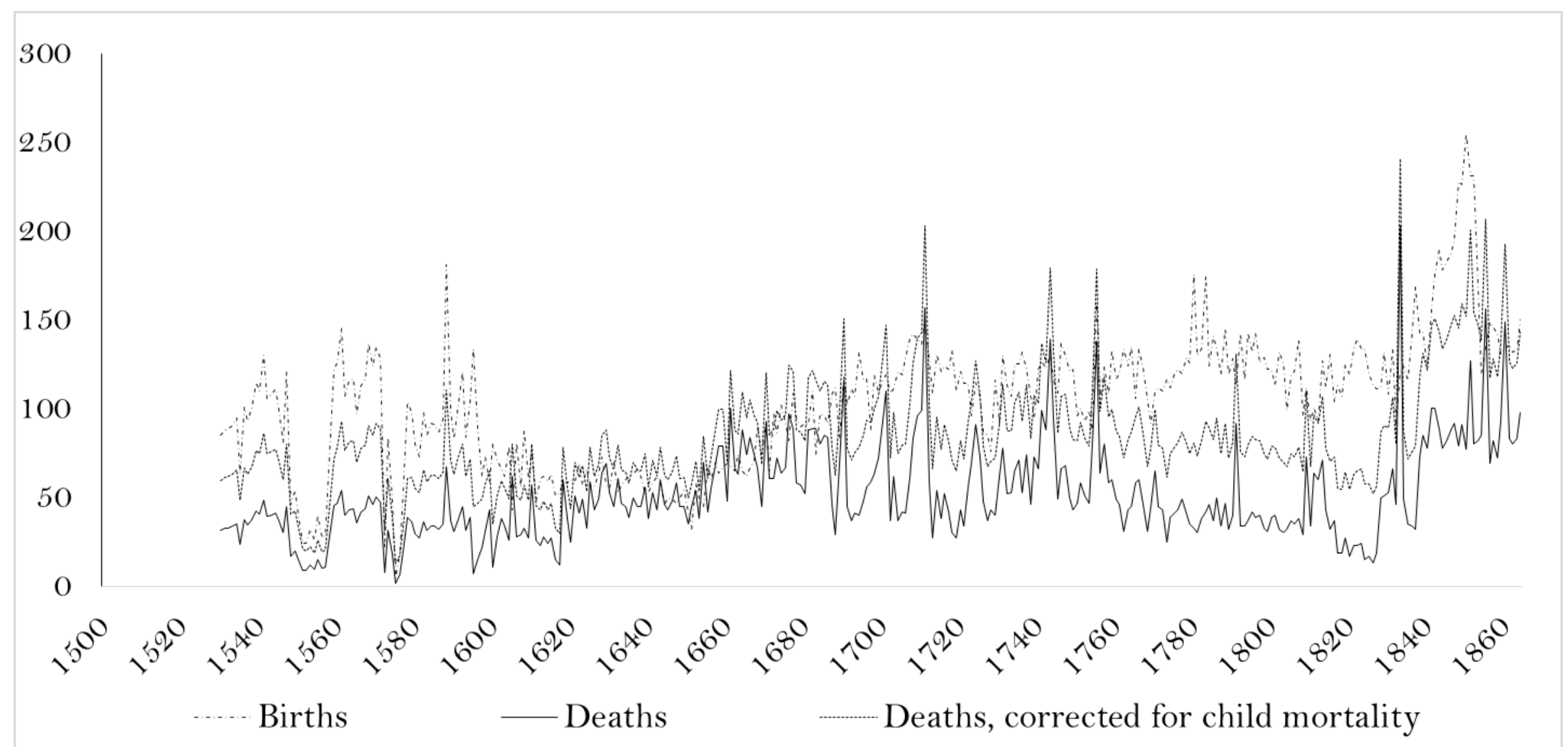

Figure 2. Births, deaths, and deaths corrected for child mortality for the village of São João Baptista de Vila do Conde. Source: entry D. 16 (Vila do Conde), online-appendix 


\subsection{Discussion of sample selection issues}

The basic assumption which we make is that the parish information that we have is representative: we assume data is missing at random. This is true both with regard to the choice of the particular parishes that we happen to have information about, and for the cases for which we have either births or deaths missing for a few years. In the latter case, the implicit assumption is that this was due to some event such as a priest who happened to be or have become lazy for exogenous reasons, as opposed to a plague which led to overstraining resources and caused registers to stop being updated. ${ }^{45}$ As noted below, the Church kept a tight monitoring system in place and this was reflected in the fact that missing data occurs quite rarely.

We have been careful to make sure that our parishes correspond to fixed geographical units over time. We stick to this rule even when it means sacrificing some data. For sure, this could be a form of sample selection, as older regions - those within city walls for instance - are selected in favour or new or growing regions. If much of the demographic increases happened in new localities ${ }^{46}$, it could seem that we underestimate population growth. This problem is minimized by several facts. Firstly, perhaps in part due to a long tradition of political and cultural uniformity, in Portugal the parish-level denomination of places has shown remarkable continuity over time (Hespanha 1994 and the foundation dates of parishes in the online appendix). Secondly, there is no a-priori reason to believe that new locations would have concentrated most demographic growth. Thirdly and most importantly, our residual correction to flows is based on observed population stocks at certain benchmarks which automatically accounts for any "invisibles" such that the population is correct at the next observable benchmark - hence at worse only some intervening high-frequency variation is lost.

Wrigley and Schoelfield (1989) recognize that their data have frequent omissions. By contrast, such occurrences are rare, if occasional, in the Portuguese case. The quality of the parish registers was rigorously scrutinized by the church through a system of "episcopal visitations" (visitações) ${ }^{47}$, a form of monitoring which covered the religious life of each community, including the behavior of the priests and the keeping of the parish books. A delegate of the bishop would visit each locality in person, and make sure, among other things, that the local priest was keeping with his obligations (Faustino 1998, p. 68-74). For our purposes the important point is that he was obliged

\footnotetext{
45 If births or deaths are missing in a given year, we extrapolate from an un-weighted average of the corresponding 5 surrounding years.

${ }^{46}$ Some people are born in the traditional areas but die elsewhere, sometimes in new locations, often after having moved there following marriage. So migration, seasonal or otherwise, was not just to the empire, but also to other parts of the country as well.

${ }_{47}$ In the parish of Calvão, for instance, visitations were often yearly, and happened at least once every three years. They were carried out randomly (Faustino 1998, p. 69). For the experience of the diocese of Coimbra, see Carvalho and Paiva (1989).
} 
to register baptisms and deaths correctly, the former immediately after occurrence, and could be punished by the church hierarchy should he fail to do so. ${ }^{48}$

\subsection{Calculation of our baseline annual stock estimates}

Consider two arbitrary moments $t$ and $t+j$ for which the population stocks are known. Then, for any $1 \leq i \leq j$, the annual stock for that year is given by

$$
p_{t+i}=p_{t+i-1}+b_{t+i}-d_{t+i}-\sum_{k=0}^{7} \delta_{t+i-k} b_{t+i-k}-e_{t+i}
$$

such that for $0 \leq i \leq j$. Here, $p$ stands for the population stock (all stocks refer to beginning-of-period quantities), $b$ is the number of recorded births in that locality, and $d$ is the number of recorded deaths. The expression $-\sum_{k=0}^{7} \delta_{t+i-k} b_{t+i-k}$ is a child mortality correction which takes the form of a MA(7) process, where each coefficient is calibrated based on the available distribution (Table 4). ${ }^{49}$ Finally, $e_{t+i}$ is a residual, which we intrepret as a measure of net emigration. ${ }^{50}$

$$
e_{t+i}=e(i, j)=\frac{c p_{t+j}-p_{t+i}}{j-i}
$$

where $c p_{t+j}$ is not the observed population at time $t+j$, but instead the counterfactual stock which would have occurred should net emigration have been zero. In other words, the residual $e_{t+i}$ is a constant that varies for each new pair of benchmarks but not within any given pair; $j$ is the number of intervening periods. Figure 3 shows an example of the resulting estimates for one of the 71 parishes.

\footnotetext{
${ }^{48}$ Priests who did not follow these rules were liable to pecuniary fines (Oliveira 2002).

49 Notice this applies even when $t+i-k<t$, that is when $i-k<0$, which means there is a "spillover" from the previous births into the current period estimates.

${ }_{50}$ Though in fairness, being a residual, it could also be capturing mismeasurement in any of the other variables or functional assumptions. Note that the residual appears with a negative sign in the main mathematical expression; this is because most of the time it is positive. In the eighteenth century, for instance, we observe large positive residuals, which adds credibility to our method since it is known that this was a period of large-scale emigration to Brazil.
} 


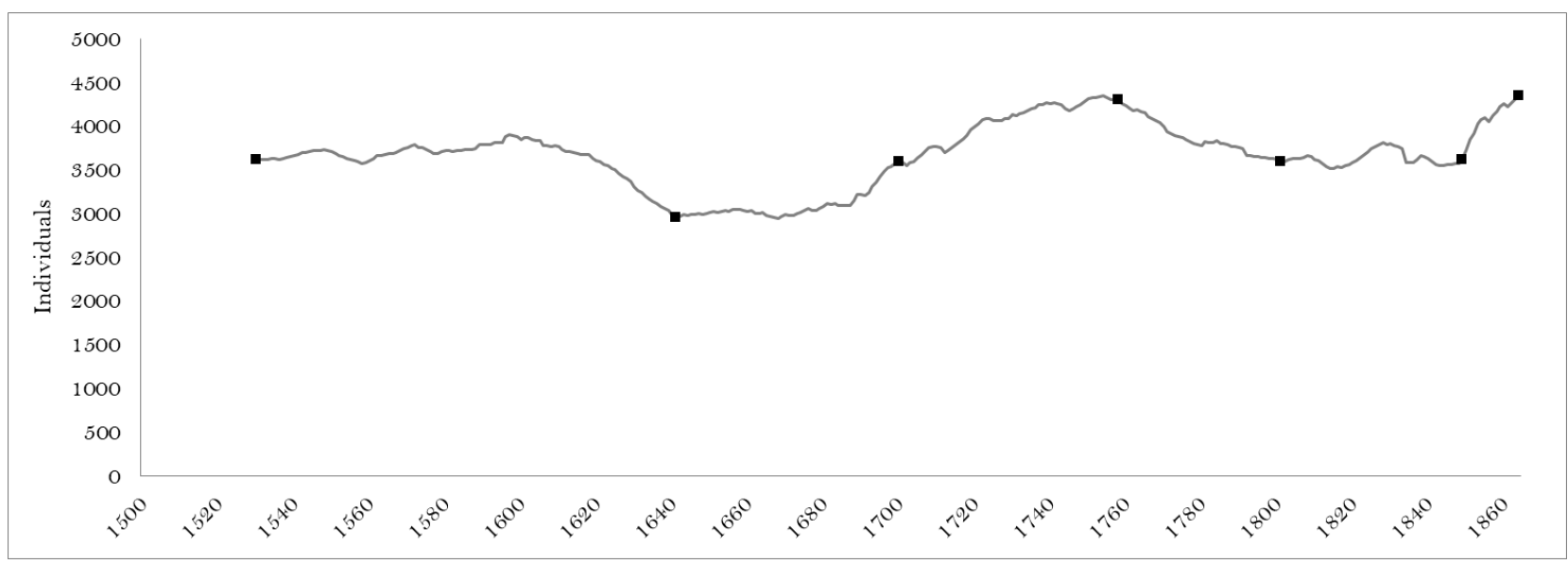

Figure 3. Estimated stocks for São João Baptista de Vila do Conde. Source: Entry D.16 (Vila do Conde), online-appendix.

\section{Regional estimates}

In order to proceed from local-level annual stocks to regional annual estimates, two complementary procedures were used. First, we calculated the respective weights of the parishes used to reconstruct the population of a region at each moment for which we can observe this information directly. ${ }^{51}$ In order to aggregate regional cestimates into a weighted national estimate, we used the regional shares from Rodrigues (2008, p.177 and 257; see also Serrão 1993) and Matos and Marques (2002, p.17). We then interpolated between the weights given to each parish, and used the resulting annual weights to aggregate local estimates into regional ones. As parishes move in and out of our sample according to when the data is available, we also annually adjusted the weights accordingly as well. For example, if one regional estimate is being based on four parishes but a fifth comes in, the weights of the other four are adjusted downwards, in a proportion that depends on the weight of the new parish which has come in. This is always possible to do since while flow data are not always available, we have earlier stock benchmarks which we can use to calculate the regional weights.

The results of these procedures are exhibited in Figure 4. They provide us with six long-run population estimates, respectively for each one of the regions of Portugal, over roughly three hundred and fifty years. Although not the main object of this paper, it is difficult to ignore the significance of these regional findings from the point of view of the celebrated debate over population development and family systems in Europe inspired by Laslett (1969) and Hajnal (1965). As the figure shows, different regions of Portugal exhibited divergent demographic patterns. The two southernmost regions Alentejo and Algarve - exhibited only minimal change over time. The northeast interior, Trás-os-Montes, had a mostly stagnant population as well. By contrast, the remaining three regions in the Centre and North of the country were the drivers of

\footnotetext{
${ }^{51}$ This usually coincides with the moments at which we can observe the local stocks as well.
} 
Portugal's demographic growth over our period, with growth rates of around 80-90 per cent per century.

In accordance with the criteria of the "historical family demography" literature (Szołtysek 2015), rather than belonging to a single family analytic group, Portugal was split into two distinct categories. One was the "north-west" type of familial behavior, to which Entre-Douro-e-Minho, Beira and Estremadura belonged. The other, the "Mediterranean" type encompassed the remaining three regions (Kertzer and Bretell 1987). Although regional comparisons are not the main object of this paper, it is difficult to ignore a key issue which these these findings and their interactions pose. How is one to explain that the "Portuguese northwest" provinces, where the stem family prevailed - with its inclination to restraining population growth (Rowland 1997) - should have been the engine of Portuguese demography?

Likewise, why was southern demography so sluggish, given its "nuclear" family type inclined to early and universal practices of marriage, which encouraged high fertility? Detailed answers are beyond the scope of this paper, but a good candidate seems to be the sustained expansion in the northwest of maize-based agriculture in the seventeenth and eighteenth centuries, a type of agriculture which was structurally suitable to this region (Palma and Reis 2019). Seasonal migration from the north fed the labor needs of the dry, extensive farms of the south, but not being permanent could never level out population densities across the country (Silbert 1966). Eighteenthcentury emigration to Brazil also originated mainly in the northwest but did not subdue this region's demographic dynamism; emigration was a regionally pathdependent process which reduced pressure on the land. 


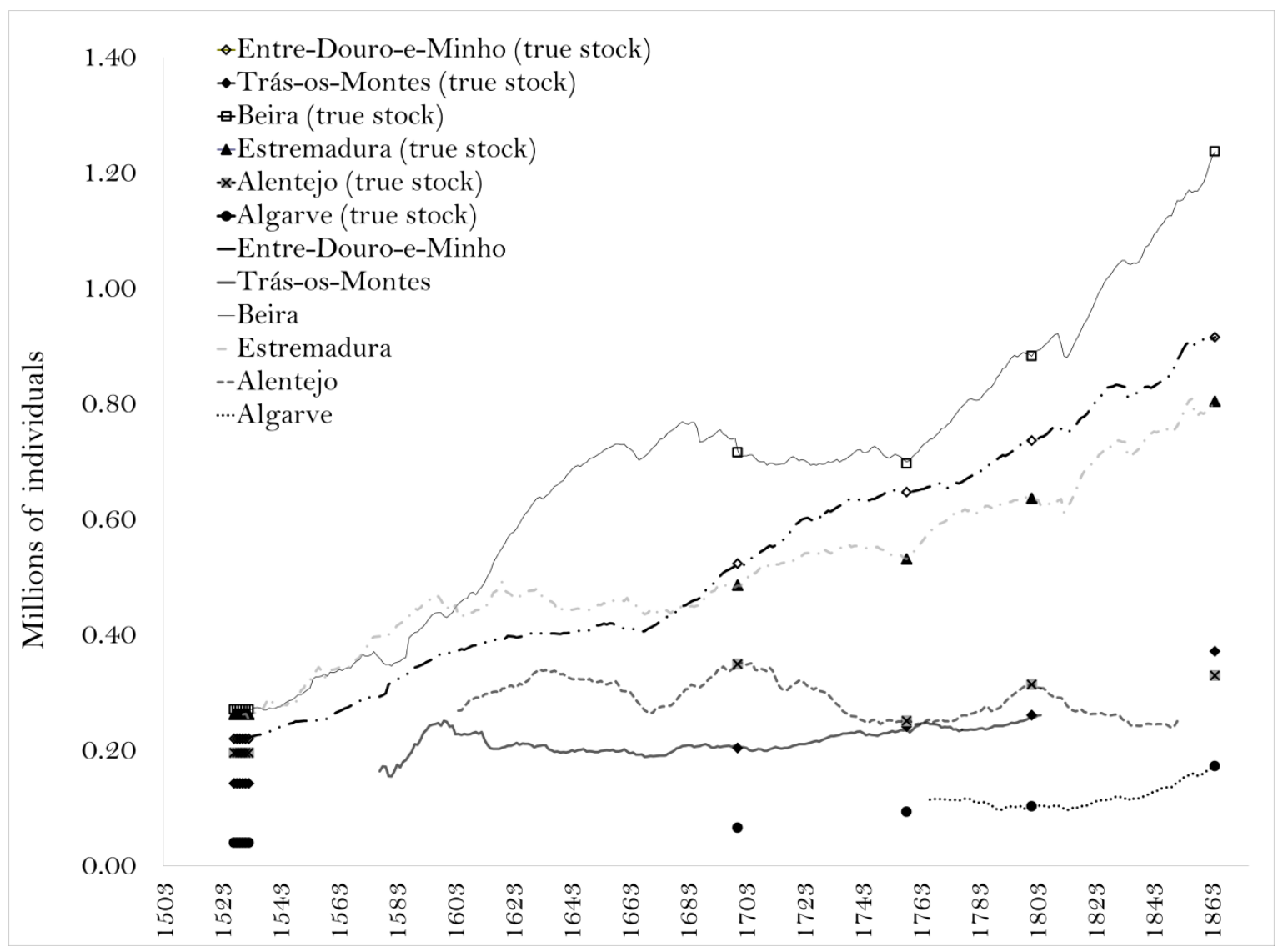

Figure 4. Regional estimates, 1527-1864. Source: our calculations; see text.

\section{National estimates and comparison with per capita GDP data}

We now estimate the annual population stock by simply aggregating the regional-level information about stocks, where each region is weighted according to its importance. While in computing the regional estimates we have used no interpolation at all, when inflating these numbers into an aggregate estimate we have used a minimal degree of interpolation on either the beginning or the end of some of the regional estimates. This is done in order to avoid capturing spurious variation provoked by the sudden entrance or exit of parishes with different demographic behavior (this is always done for periods for which other regional estimates with "true" high frequency variation also exist for the period at stake). ${ }^{52}$ In Figure 5 we present the result of our aggregation of the regional data, as well as the population stocks known from the hearth counts and censuses and the historians' benchmark guesstimates from Table 1. In Figure AA2 of the Appendix, we also show the results under the alternative assumiptions of 3.5 or 4.5 people per hearth; they do not change much. Note that the distinction is only relevant until the $19^{\text {th }}$ century, as from then onwards we can use actual population numbers which do not require a conversion.

52 The full list of parishes and periods for which this was done is very short: Viseu (interpolated 1840 to 1863), Guimarães (1530 to 1579) and Ventosa (1530 to 1558). In the case of Barcarena, we assumed that the migration residual for 1588-1619 is equal to that of 1620-1706. 
In Figure 6, we show real income per capita against the national population numbers that we have estimated in the present paper. The figure clearly shows that the Malthusian model does not apply well to long stretches of Portugal's early modern history. This economic experience is especially striking in light of the statement by Broadberry et al (2015, p. 212) that in Britain, "[In the period 1780-1830 $]$ for the first time the Kuznets condition of simultaneous growth of both GDP per head and population was being met". As Figure 6 shows, Portugal in fact went through an earlier episode of this nature, which was rather prolonged: it lasted from about 1630 (or even the 1580s) to the 1780 s. There was a slowdown in net population growth over the first half of the eighteenth century mostly due to emigration to Brazil, but it remained positive. Once past the 1750s, the sources of income expansion began to peter out, but income levels stayed high as strong population growth resumed. As economic performance started to contract strongly from the 1780 s, population grew strongly and in half a century all of the GDP per capita gains since the 1630 or earlier were wiped out. Thereafter income per person continued to decline, with the consequence that by the middle of the nineteenth century Portugal became one of Europe's most backward economies, precisely as the era of modern economic growth was beginning in other Western European countries. ${ }^{53}$

${ }^{53}$ Around 1850 Portugal's per capita GDP was close to the levels of the Scandinavian countries, and higher than Greece and southern Italy (Reis 2000). 


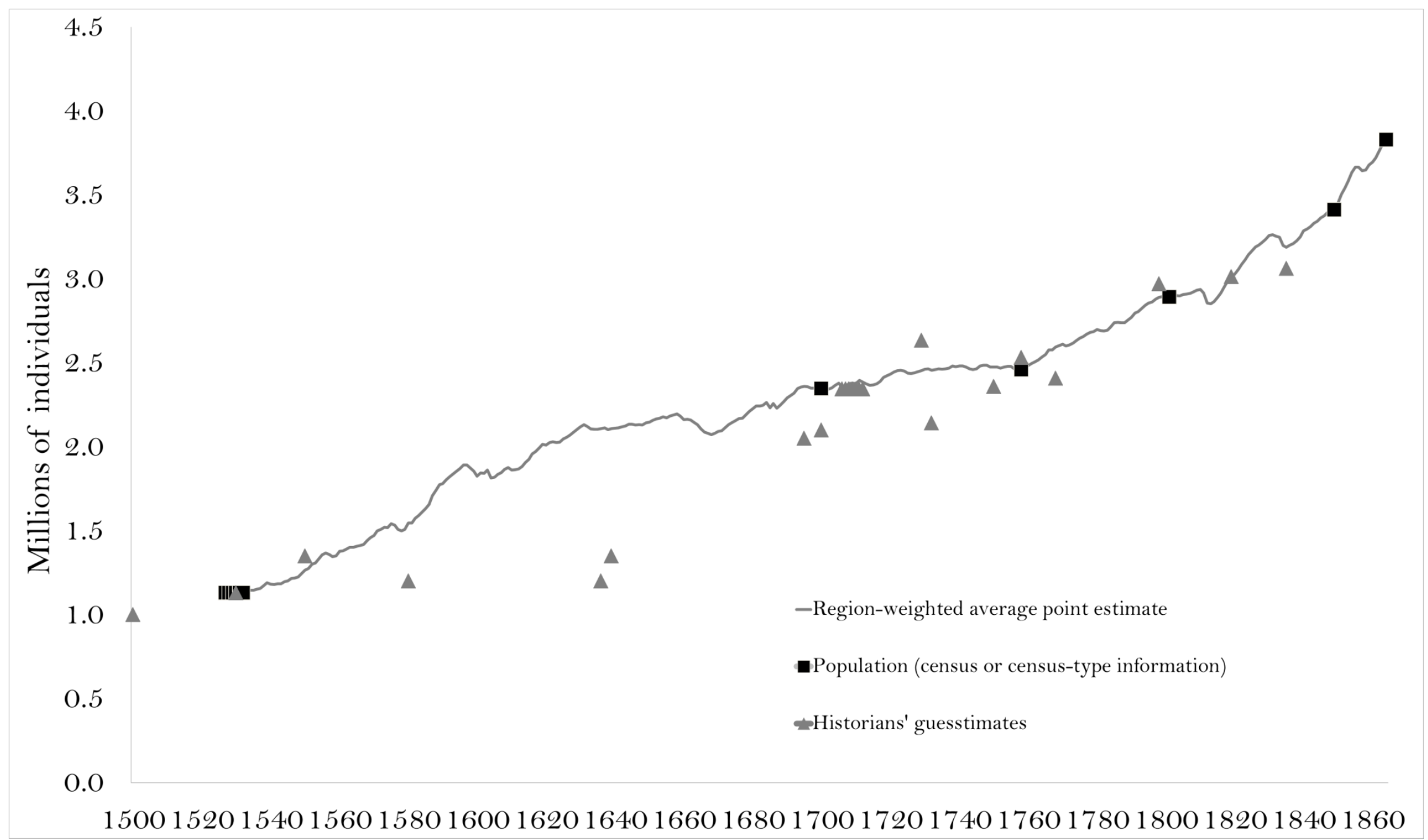


Figure 5. National population estimates (region-weighted), 1527-1864. Sources: see text.

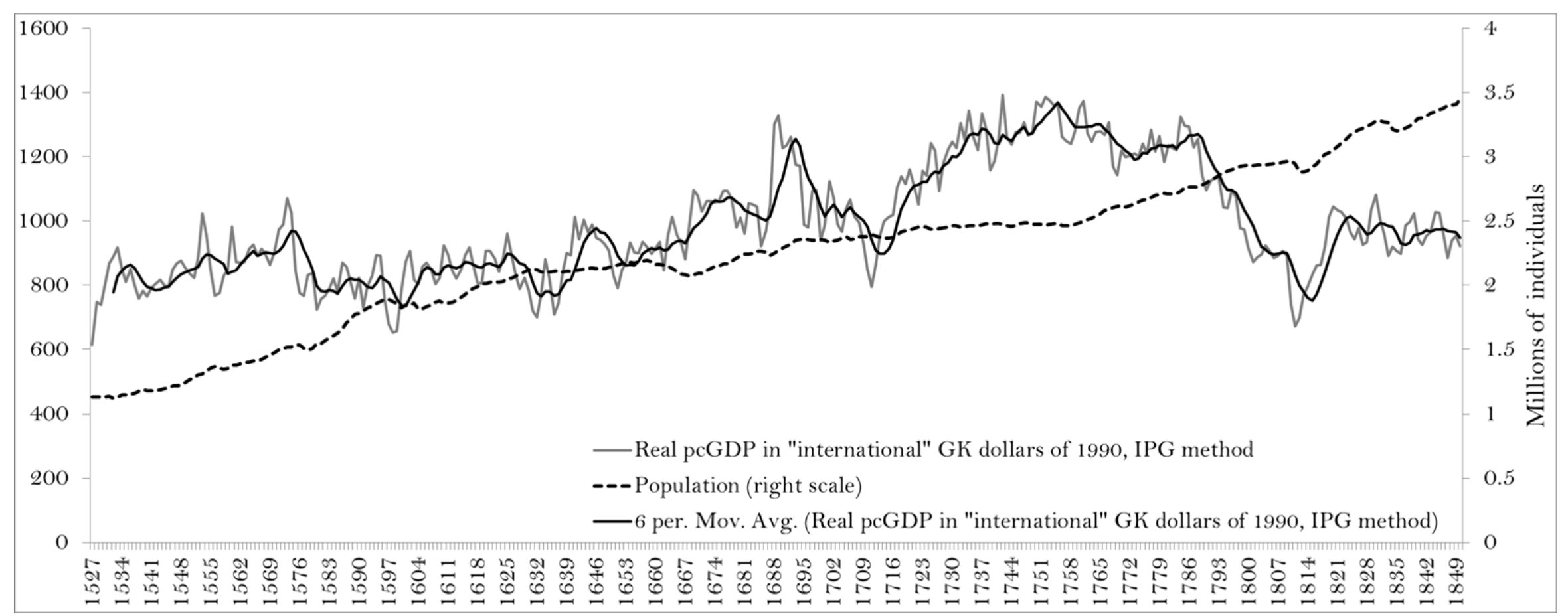

Figure 6. GDP per capita in constant, 1990 "international" Geary Khamis prices, and national population for Portugal, $1527-1850$. Sources: for GDP, Palma and Reis (2019). IPG stands for inter-productivity gap, the baseline method used in that paper. For population, the present paper. 


\section{Conclusion}

In this study we have reconstructed Portugal's annual population for 1527-1864 at the local, regional, and national levels. Some measurement error is unavoidable at the annual level, but our method and data presents advantages over the seminal Wrigley and Schofield (1989) study for England. We are fortunate to have several usable "census-type" estimates, which together with the new mathematical methodology which we propose here, permits the reconstruction of population under much lighter assumptions than those required by the back projection techniques used by Wrigley and Schofield. This is fortunate as using such techniques would lead to biases in the estimates, given that both back projection and generalized back projection methods are well-known to present problems when migration rates are not negligible ${ }^{54}$ - as is surely the case of Portugal. We have critically discussed the quality of our data. While not perfect, we have strived to incorporate all the relevant information that, to the best of our knowledge, is available, while considering alternatives when some of the sources did not seem reliable. Finally, we have shown that Portugal witnessed a period of simultaneous growth in both population and real income per capita, lasting for more than 100 years. Ultimately, however, real income per person converged back towards long-run historical levels.

\section{REFERENCES}

\section{Primary Sources}

Project Historical Atlas, available at: http://atlas.fcsh.unl.pt/cartoweb35/atlas.php?lang=pt

\section{Secondary Sources}

Alves, Jorge Fernandes (1986). S. Tiago do Bougado, 1650-1849, Master's dissertation, Faculdade de Letras, Universidade do Porto.

Amorim, Maria Norberta, (1983-4). S. Pedro de Poiares e a sua população de 1561 a 1830. Brigantia: Revista de Cultura 3, pp. 273-304, 337-418, 531-576; 4, pp. 83-121, 311-333.

Amorim, Maria Norberta (1987). Guimarães 1580-1819: Estudo demográfico. Lisboa: Instituto Nacional de Investigação Científica.

Amorim, Maria Norberta (1992). Evolução demográfica de três paróquias do Sul do Pico: 1680-1980. Braga: Universidade do Minho.

Amorim, Maria Norberta (1999). Francisca Catarina, 1846-1940. Vida e raízes em S. João do Pico: biografia, genealogia e estudo de comunidade. (Guimarães: Universidade do Minho).

${ }^{54}$ See for instance, Wrigley and Schofield (1989, p. xvi-xvii). We leave a more detailed study of emigration to future work. We note that the residual can be further refined through consideration of archival materials such as shipping statistics and masculinity ratios at the parish level. 
Bairoch, P. (1976). Europe's Gross National Product: 1800-1975. Journal of European Economic History 5, pp. 273-340.

Broadberry, S., Campbell, B. M., Klein, A., Overton, M., and Van Leeuwen, B. (2015). British economic growth, 1270-1870. Cambridge University Press.

Calderón-Fernández, Andrés, García-Montero, Héctor and Enrique Llopis-Agelán (2017). New research guidelines for living standards, consumer baskets, and prices in Madrid and Mexico. No 97 Working Paper, "Carlo F. Dondena" Centre for Research on Social Dynamics (DONDENA).

Carvalho, Joaquim de and Paiva, José Pedro (1989). A evolução das visitações pastorais na diocese de Coimbra nos séculos XVII e XVIII. Ler História 15, pp. 29-41.

Chiarini, Bruno (2010) Was Malthus right? The relationship between population and real wages in Italian history, 1320 to 1870. Explorations in Economic History 47, pp. 460-475.

Chorão, José Maria Bigotte (1987). Inquéritos promovidos pela Coroa no século XVIII. Revista de História Económica e Social 21, pp. 93-119.

Colaço, João Telo Magalhães (1934). Cadastro da População do Reino (1527). Actas das Comarcas dantre Tejo e Odiana e da Beira, Revista da Faculdade de Direito da Universidade de Lisboa, II, pp. 28- 243.

Cosme, João (2017). A população do Patriarcado de Lisboa (1717-1748). Casal de Cambra: Caleidoscópio.

Costa, António Carvalho da (1706-1712). Corografia portugueza e descripçam topografica do famoso Reyno de Portugal, com as noticias das fundações das cidades, villas, Eீ lugares, que contem; varões illustres, genalogias das familias nobres, fundações de conventos, catalogos dos Bispos, antiguidades, maravilhas da natureza, edificios, छ outras curiosas observaçoens. Lisboa: Oficina de Valentim da Costa Deslandes, 3 vols.

Costa, Francisco Barbosa (1994). S. João Baptista de Canelas. Uma comunidade rural da Terra de Santa Maria: Um estudo demográfico, 1588-1808. Vila Nova de Gaia: Afonseiro Edições.

Costa, L. F., Palma, N., and Reis, J. (2015). The great escape? The contribution of the empire to Portugal's economic growth, 1500-1800. European Review of Economic History, 19(1), 1-22.

Deaton, Angus (2013). The great escape: Health, wealth, and the origins of inequality. Princeton: Princeton University Press.

Del Panta, L. and Livi Bacci, M. (1980). Le componenti naturali dell'evoluzione demografica nell'Italia del settecento. In S.I.D.E.S (Ed.), La popolazione Italiana nel Settecento. Bologna: CLUEB, pp. 71-139.

Dias, João A. (1996) Gentes e Espaços (em torno da população portuguesa na primeira metade do século XVI). Lisboa: Gulbenkian, JNICT.

Dias, João A. (1998). “A população”. In Serrão, Joel and Marques, A.H. Oliveira (eds): Nova História de Portugal. Lisboa: Presença

Dupâquier, J. (1988). Histoire de la population française. Paris: Publications Universitaires Françaises 
Drelichman, Mauricio and González Agudo, David (2014). Housing and the cost of living in early modern Toledo. Explorations in Economic History 54, pp. 27-47.

Dupâquier, J. (1988). Histoire de la population française. Paris: PUF.

Edvinsson, Rodney (2015). Recalculating Swedish pre-census demographic data: Was there acceleration in early modern population growth? Cliometrica 9, pp. 167-1.

Emigh, Rebecca Jean (2002). Numeracy or Enumeration? The uses of numbers by states and societies. Social Science History 26 (4), pp.653-697.

Emigh, Rebecca Jean, Riley, Dylan and Patricia Ahmed (2016). Antecedents of censuses from medieval to national states: How societies and states count. New York, NY: Palgrave Macmillan.

Estatística de Portugal (1868). População. Censo de Portugal no $1^{\circ}$ de Janeiro 1864. Lisboa: Imprensa Nacional

Faustino, José A. (1998). Calvão: Uma paróquia rural do Alto Tâmega (1670-1870). Chaves: NEPS.

Fernihough, Alan (2013). Malthusian dynamics in a diverging Europe: Northern Italy, 1650-1881. Demography, 50, pp. 311-33.

Freire, Anselmo Braamcamp (ed.) (1903-1916). Cadastro da População do Reino (1527-1532), Archivo Historico Portuguez (Facsimile reproduction 2001) (Santarem: 2001), vols. III, IV, VI and VII.

Galloway, P. R. (1988). Basic patterns in annual variations in fertility, nuptiality, mortality, and prices in pre-industrial Europe. Population Studies 42, pp. 275-303.

Galloway, P.R. (1994). A reconstruction of the population of North Italy from 1650 to 1881 using annual inverse projection with comparisons to England, France, and Sweden. European Journal of Population 10, pp. 223-274.

Godinho, Anabela (2010). Lisboa Pré-Pombalina: A freguesia da Sé, demografia e sociedade (1563-1755). Ph.D. dissertation, Lisboa: ISCTE.

Godinho, Vitorino M. (1980). A estrutura da antiga sociedade. Lisboa: Arcádia.

Godinho, Vitorino M. (1978). L'émigration portugaise (XVe-XXe siècles). Une constante structurale et les réponses aux changements du monde. Revista de História Económica e Social 1, pp. 5-32.

Godinho, Vitorino M. (1955). Prix et monnaies au Portugal, 1750-1850. Paris: Armand Colin

Hajnal, John (1965). European marriage patterns in perspective. In: D. V. Glass and D. E. C. Eversley (eds.), Population in History. Chicago: Aldine Publishing

Hespanha, António M. (1994). As vésperas do Leviathan - Instituições e poder político em Portugal - Séc. XVII. Coimbra: Almedina.

Hespanha, António M. (2010). Imbecillitas, As bem-aventuranças da inferioridade nas sociedades de Antigo Regime. São Paulo: Anablume. 
Kertzer, David and Bretell, Caroline (1987). Advances in Italian and Iberian family history. Journal of Family History 12 (1-3), pp. 87-120.

King,Wayne E., Adams, Paul Vauthier, Langer, Erick Detlef, Hwa, Lily, Stearns, Peter N. and Merry E. Wiesner-Hanks (2000). Experiencing world history. New York: New York University Press.

Laslett, Peter (1969). Size and structure of the household in England over three centuries. Population Studies 23 (2) pp. 199-223.

Lee, R. (1974). Estimating series of vital rates and age structures from baptisms and burials: A new technique, with applications to pre-industrial England. Population Studies, 28(3), 495-512.

Lee, R. (1985) Inverse Projection and Back Projection: A Critical Appraisal, and Comparative Results for England, 1539 to 1871. Population Studies, 39 (2), 233-248.

Livi Bacci, Massimo (2002). 500 anos de demografia brasileira: uma resenha. Revista Brasileira de Estudos de População 19, pp. 141-159.

Loveman, Mara (2014). National Colors: Racial Classification and the State in Latin America. Oxford: Oxford University Press

Maddison, A. (2006). The world economy. Paris: Organisation for Economic Cooperation and Development. 2 volumes

Magalhães, Joaquim R. (1988). O Algarve económico. 1600-1773. Lisboa: Estampa.

Malanima, Paolo (2009). Pre-Modern European Economy. One thousand years (10th -19th centuries). Leiden: Brill.

Marques, A.H. de Oliveira and Dias, João J. Alves (2003). Atlas histórico de Portugal e do Ultramar Português. Lisboa: Centro de Estudos Históricos.

Matos, Paulo (2016). Counting colonial populations in the Portuguese colonial empire, 1776- 1875. A research note. The History of the Family, vol. XXI, pp.267-80.

Matos, Paulo and A. H. de Oliveira Marques (2002). A base demográfica. In Serrão, Joel and A. H. de Oliveira Marques (eds). Nova História de Portugal IX. Lisboa: Presença, pp. 13-45.

Miranda, Fernando Silva (1993). Estudo demográfico de Alvito S. Pedro e anexa, 1567-1989. Barcelos: Junta de Freguesia de Alvito S. Pedro.

Mols, Roger (1966). Introduction à la démographie historique des villes d'Europe du XVeme au XVIIIeme siècles. Louvain: Gembloux, 3 vols.

Neto, Maria de Lurdes (1967). A freguesia de Nossa Senhora das Mercês de Lisboa no $1^{o}$ quartel do século XVIII: Ensaio de demografia histórica. Lisboa: Centro de Estudos Demográficos. 
Neto, Maria de Lurdes (1967). A freguesia de Nossa Senhora das Mercês de Lisboa no $1^{o}$ quartel do século XVIII: ensaio de demografia histórica. Lisboa: Centro de Estudos Demográficos.

Nicolini, E. (2007). Was Malthus right? A VAR analysis of economic and demographic interactions in pre-industrial England. European Review of Economic History 11, pp. 99-121.

Oeppen, J. (1993). Back projection and inverse projection: members of a wider class of constrained projection models. Population Studies, 47(2), 245-267.

Oliveira, António de (2015). Capítulos de História de Portugal. Coimbra: Palimage, 3 vols.

Oliveira, João Nunes de (2002). A Beira Alta de 1700 a 1840: Gentes e subsistências. Viseu: Palimage.

Oliveira, João Nunes de (1990). A Produção agrícola de Viseu entre 1550 e 1700 . Viseu: Câmara Municipal de Viseu.

Osswald,Helena (2008). Nascer, viver e morrer no Porto de seiscentos. Ph.D. dissertation, Faculdade de Letras, Porto University.

Palma, Nuno and Jaime Reis (2019). From convergence to divergence: Portuguese economic growth, 1500-1850. Journal of Economic History 79 (2), pp.477-506.

Pinto, Maria Luís, Rodrigues, José D. and Artur Madeira (2001). A base demográfica. In Serrão, Joel and Marques, A.H. Oliveira (eds). Nova História de Portugal, VII. Lisboa: Presença, pp. 385-405.

Pfister U. and G. Fertig (2010) The population history of Germany: research strategy and preliminary results,MPIDR working paper WP no. 2010 035. http://www.demogr.mpg.de/papers/working/wp2010-035.pdf

Reis, Jaime (2000). How Poor Was the European Periphery before 1850? The Mediterranean vs. Scandinavia. In: The Mediterranean Response to Globalization before 1950, edited by Sevket Pamuk and Jeffrey G. Williamson, 17-44. London: Routledge.

Reis, J. (2017). Deviant behaviour? Inequality in Portugal 1565-1770. Cliometrica, 11(3), 297-319.

Reher, David Sven (1988). Família, Poblacióm y Sociedad en la provincia de Cuenca 1700-1870. Madrid: Siglo Veinteuno.

Rodrigues, Teresa Ferreira (ed.) (2008). História da população portuguesa: Das longas permanências à conquista da modernidade. Porto: Afrontamento.

Rowland, Robert (1997). População, família, sociedade. Portugal, séculos XIX-XX. Oeiras: Celta.

Santos, Carlota and Matos, Paulo de (eds) (2013). A demografia das sociedades insulares portuguesas. Séculos $X V$ a XXI. Braga: CITCEM.

Santos, Rui (2003). Sociogénese do latifundismo moderno: Mercados, crises e mudança social na região de Évora, séculos XVII a XIX. Lisboa: Banco de Portugal. 
Serrão, Joaquim V. (1970). A população de Portugal em 1798: O censo de Pina Manique. Paris: Fundação Calouste Gulbenkian, Centro Cultural Português.

Serrão, Joaquim V. (1975). Uma estimativa da população portuguesa em 1640. Memórias da Academia de Ciências de Lisboa - Classe de Letras. Lisboa: Academia de Ciências de Lisboa

Serrão, Joaquim V. (1995). História de Portugal. Lisboa: Verbo, 15 vols.

Serrão, José V. (1993). O quadro humano. In José Mattoso (ed.) História de Portugal. Lisboa: Círculo de Leitores, vol IV.

Silbert, Albert (1966). Le Portugal méditérranéen à la fin de l'ancien regime XVIIIe-début du XIXe siècle: Contribution à l'histoire agraire comparée. Paris: S.E.V.P.E.N., 2 vols.

Silva, Cristina Nogueira da (2001). "Introdução", in: Corografia Portuguesa, Comissão Nacional para a Comemoração dos Descobrimentos Portugueses. Lisboa: Colecção Ophir.

Silveira, Luís Nuno Espinha da et al.(eds) (2001). Os recenseamentos da população portuguesa de 1801 e 1849. Lisboa: INE.

Sousa, Fernando de (1979). A população portuguesa nos inícios do século XIX. PhD. dissertation, Faculdade de Letras, University of Porto.

Sousa, Fernando de (1995). História da Estatística em Portugal. Lisboa: Instituto Nacional de Estatística.

Stolz, Y., Baten, J., and J. Reis (2013). Portuguese living standards, 1720-1980, in European comparison: heights, income, and human capital. The Economic History Revierw, 66(2), pp. 545-578.

Szołtysek, M. (2015). Households and family systems. In: The Oxford Handbook of Early Modern European History, 1350-1750: Volume I: Peoples and Place (ed. Hamish Scott). Oxford: Oxford University Press

Wrigley, E. A. (2009). Rickman revisited: the population growth rates of English counties in the early modern period. The Economic History Review, 62(3), 711-735.

Wrigley, E. A. and R. S. Schofield (1989). The population history of England 1541-1871. Cambridge: Cambridge University Press.

Wrigley, E. A., Davies, R. S., J. E. Oeppen and R. S., Schofield (1997). English population history from family reconstitution 1580-1837. Cambridge: Cambridge University Press. 


\section{Online appendix to}

\section{"Reconstruction of Regional and National Population USing Intermittent Census-Type Data: the Case of Portugal, 1527-1864" \\ N. Palma, J. Reis and M. Zhang - forthcoming, Historical Methods}

In this appendix, we describe the data sources and show graphs for the dynamic evolution of population at the parish level, for the six regions of the country, as well as the particular assumptions used in each case when needed.

\section{A. $\quad$ Alentejo}

A1. S. Marcos da Abóbada (Évora) (1720-1851)

Location: the province of Alentejo and the archbishopric of Évora. A small rural parish in the hinterland of the city and municipality of Évora.

Presently in the district of Évora, the parish dates back to circa 1555.

Population stock (number of inhabitants):

1530: No data. The Numeramento da População does not cover localities in Alentejo at the parish level.

1700: No data. Santos (2003, 173) considers Costa (1706-1712) unsuitable for the region of Évora.

1720: 132 Santos (2003, pp.188-9).

1758: 256 Memórias Paroquiais, cited in Santos (2003, pp. 188-9).

1801: 286 Silveira (2001).

1849: 367 Silveira (2001).

1864: 300 Censo (1868).

Source for births and deaths: Santos (2003). 


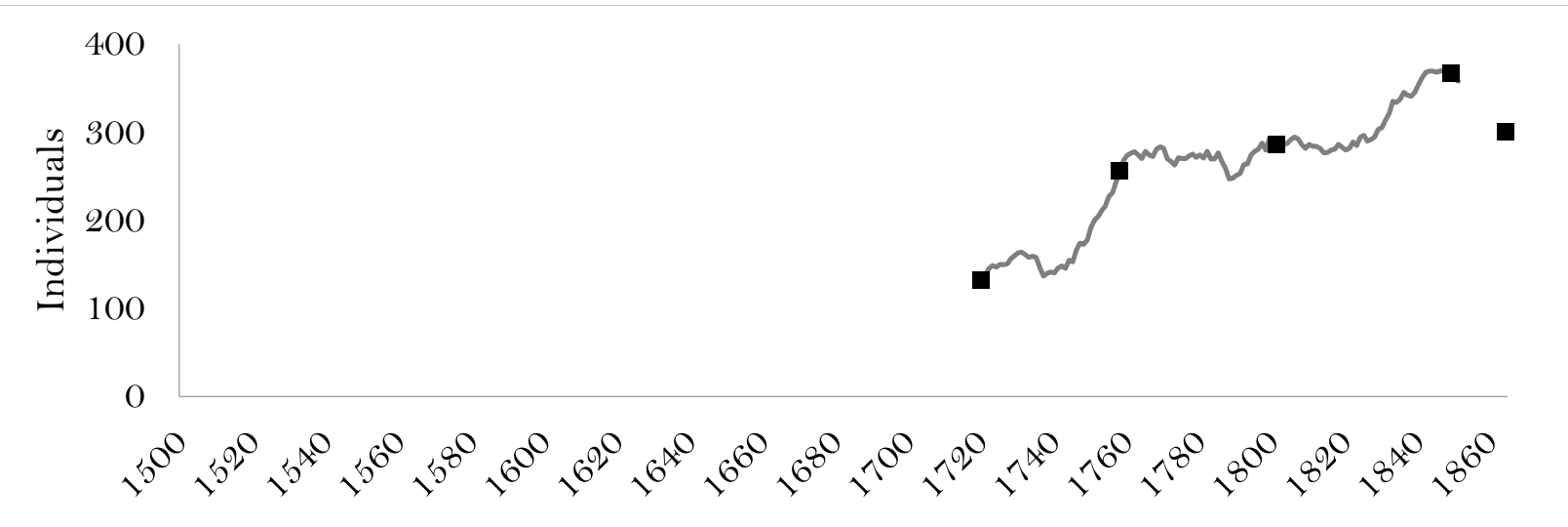

Figure A1. S. Marcos da Abóbada (Évora)

\section{A2. S. Miguel de Machede (Évora) (1720-1851)}

Location: the province of Alentejo and the archbishopric of Évora. A small rural parish in the hinterland of the city and municipality of Évora. Presently in the district of Évora, its origins go back to before 1500.

Population stock (number of inhabitants):

1530: No data. The Numeramento da População does not cover localities in Alentejo at the parish level.

1700: No data. Santos (2003: 173) considers Costa (1706-1712) unsuitable for the region of Évora.

1720: 784 Santos (2003, pp. 188-9).

1758: 1,200 Memórias Paroquiais, cited in Santos (2003, pp. 188-9).

1801: 1,446 Silveira (2001).

1849: 1,479 Silveira (2001).

1864: 1,466 Censo (1864).

Sources for births and deaths: Santos (2003). 


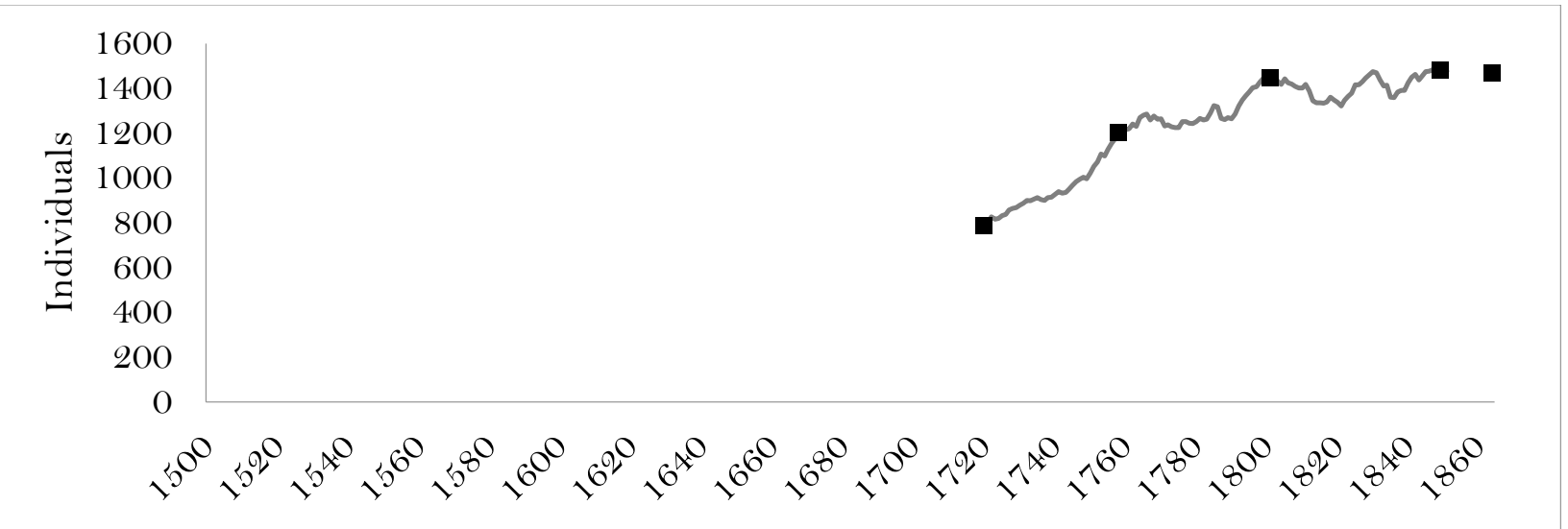

Figure A2. S. Miguel de Machede (Évora)

\section{A3. S. Matias (Évora) (1720-1851)}

Location: the province of Alentejo and the archbishopric of Évora. A small rural parish in the hinterland of the city and municipality of Évora. Presently, in the district of Évora. Its origins lie in the sixteenth century.

Population stock (number of inhabitants):

1530: No data. The Numeramento da População does not cover localities in Alentejo at the parish level.

1700: No data. Santos (2003, p. 173) considers the use of the Corografia of Costa (1706-1712) unsuitable for the Évora region.

1720: 496 Santos (2003, pp. 188-9).

1758: 600 Memórias Paroquiais. Cited in Santos (2003, pp.188-9).

1801: 485 Silveira (2001).

1849: 521 Silveira (2001).

1864: 484 Censo (1868).

Source for births and deaths: Santos (2003). 


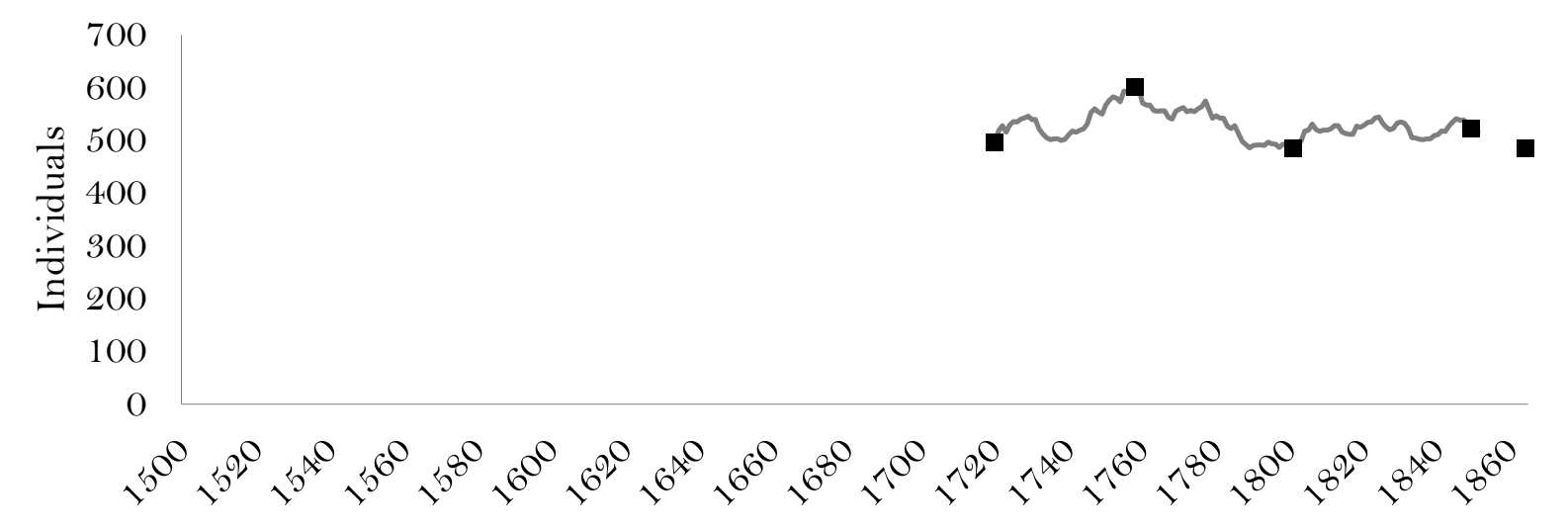

Figure A3. S. Matias (Évora)

A4. S. Vicente do Pigeiro (Évora) (1720-1851)

Location: the province of Alentejo and the archbishopric of Évora. A small rural parish in the hinterland of the city and municipality of Évora. Presently in the district of Évora. Its origin is unknown.

Population stock (number of inhabitants):

1530: No data. The Numeramento da População does not cover localities in Alentejo at the parish level

1700: No data. Santos (2003: 173) considers the use of the Corografia of Costa (1706-1712) unsuitable for the Évora region.

1720: 332 Santos (2003, pp. 188-9).

1758: 364 Memórias Paroquiais, cited in Santos (2003, pp. 188-9).

1801: 352 Silveira (2001).

1849: 351 Silveira (2001).

1864: 440 Censo (1868).

Source for births and deaths: Santos (2003). 


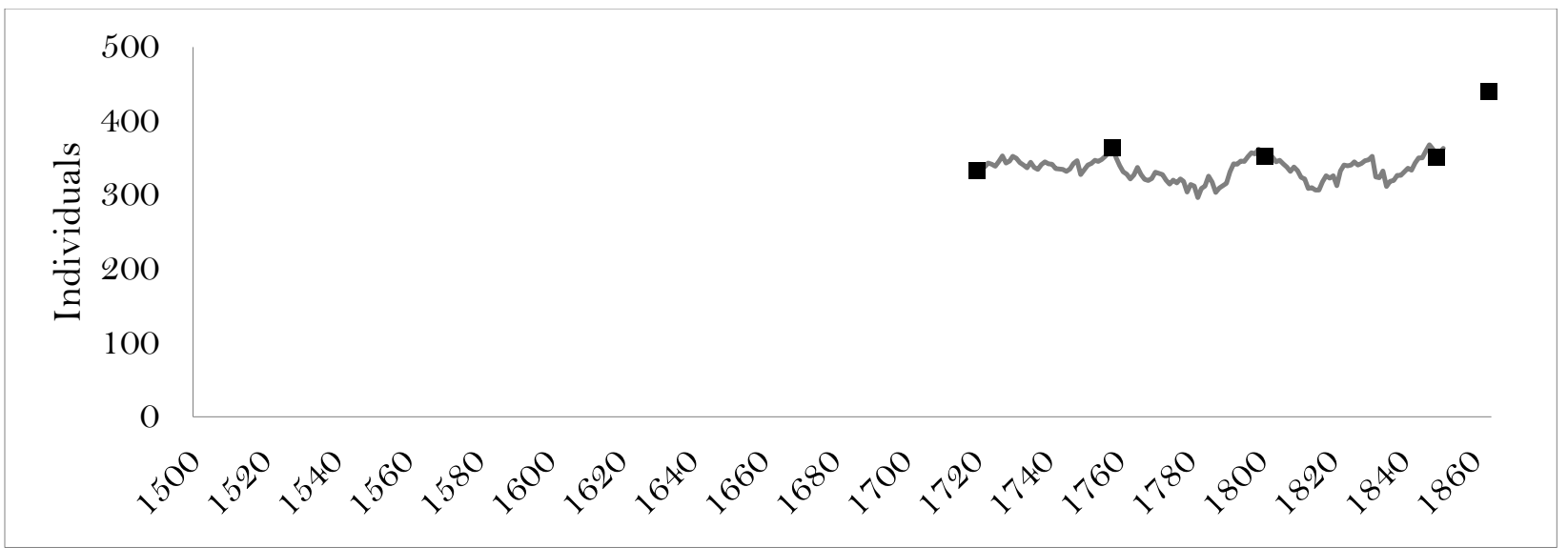

Figure A4. S. Vicente do Pigeiro (Évora)

\section{A5. S. Maria do Castelo (Évora) (1604-1851)}

Location: In the province of Alentejo and the archbishopric of Évora. One of the two urban parishes in the small fortified town of Évora Monte, the other one being S. Pedro do Castelo. Presently in the district of Évora, its parish church dates back to 1359 .

Population stocks (number of inhabitants):

1530: No data. The Numeramento da População does not cover localities in Alentejo at the parish level.

1604: 252 Serrão (1974) cited by Serrão (2003, p.188) and interpolated using 1720 data.

1700: No data. Santos (2003, p.173) considers Costa (1706-1712) unsuitable for the region of Évora.

1720: 424 Santos (2003, pp. 188-9).

1758: 724 Memórias Paroquiais. Cited in Santos (2003, pp. 188-9).

1801: 1,532 Silveira (2001).

1849: 570 Silveira (2001).

1864: 1,181 Censo (1868).

Source for births and deaths: Santos (2003). 


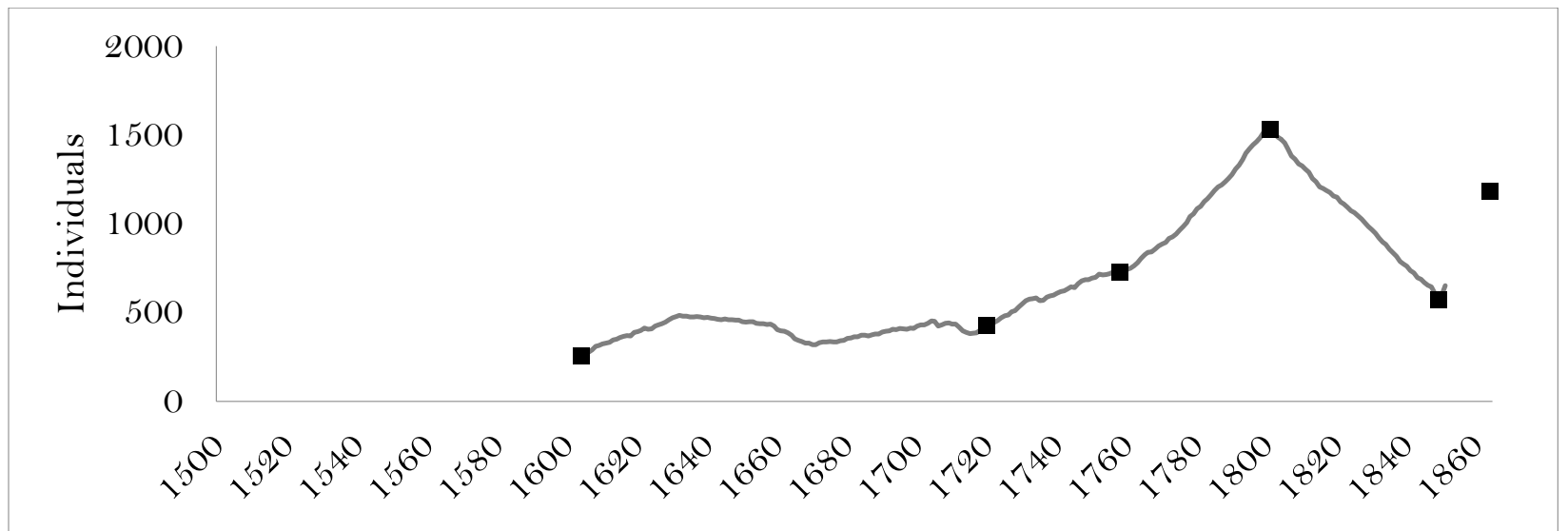

Figure A5. S. Maria do Castelo (Évora)

\section{A6. S. Pedro do Castelo (Évora) (1604-1851)}

Location: in the province of Alentejo and the archbishopric of Évora. One of the two urban parishes in the small fortified town of Évora Monte, the other one being S. Maria do Castelo. Presently, in the district of Évora, its parish church dates back to 1320 .

Population Stock (number of inhabitants):

1530: No data. The Numeramento da População does not cover localities in Alentejo at the parish level.

1604: 348 Serrão(1974) cited by Santos (2003, p.188) and interpolated using 1720 data.

1700: No data. Santos (2003, p. 173) considers the use of the Corografia (1706-1712) of Costa unsuitable for the Évora region.

1720: 288 Santos (2003, pp.188-9).

1758: 360 Memórias Paroquiais. Cited in Santos (2003, p.188).

1801: 380. Santos (2003, p.188) gives this figure without clearly explaining how it was obtained We opt for this statistic given the careful scholarship of this source and because the census of 1801 (Silveira 2001) does not provide a separate statistic for this parish.

1849: 409 Silveira (2001). 
1864: 498 Censo (1868).

Source for births and deaths: Santos (2003).

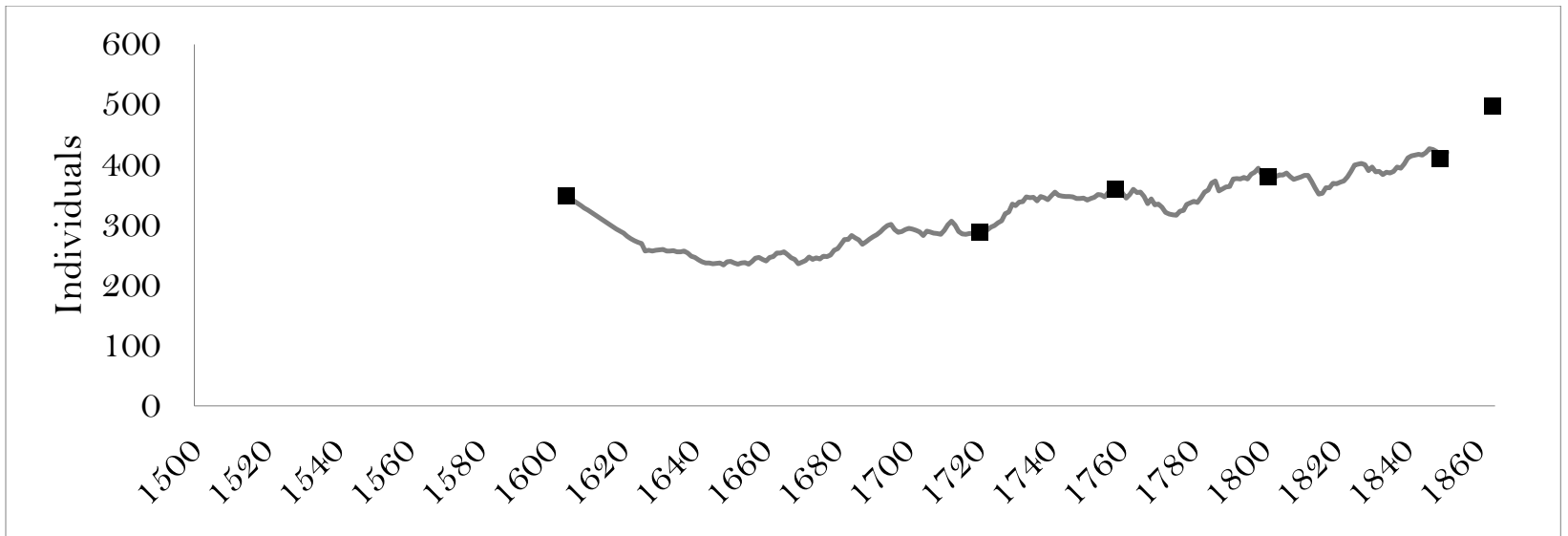

Figure A6. S. Pedro do Castelo (Évora)

\section{A7. Nossa Senhora da Boa Fé (1720-1851}

Location: in the province of Alentejo and the archbishopric of Évora. A small rural parish in the hinterland of the city and municipality of Évora. Presently, in the district of Évora. Its origins go back to the second half of the fourteenth century but the actual parish church was probably built in the early sixteenth.

Population stock (number of inhabitants):

1530: No data available. The Numeramento da População does not cover localities in Alentejo at the parish level.

1700: No data. Santos (2003: 173) considers the Corografia of Costa (17061712) unsuitable for the region of Évora.

1720: 276 Santos (2003, pp. 188-9).

1758: 336 Memórias Paroquiais, cited in Santos (2003, pp. 188-9).

1801: 380 Silveira (2001).

1849: 321 Silveira (2001). 
1864: 346 Censo (1868).

Source for births and deaths: Santos (2003).

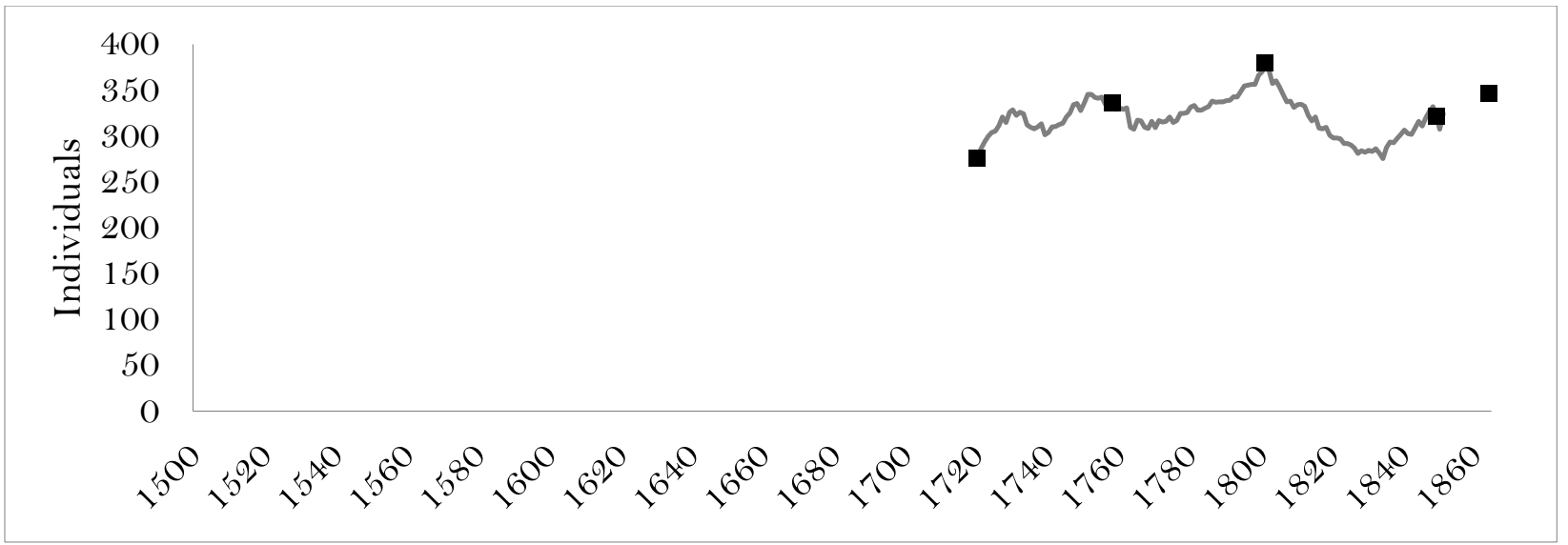

Figure A7. Nossa Senhora da Boa Fé (Évora)

A8. Nossa Senhora da Graça do Divor (Évora) (1720-1851)

Location: in the province of Alentejo and the bishopric of Évora. A small rural parish in the hinterland of the city and municipality of Évora. Presently, in the district of Évora, the earliest reference to its existence dates back to 1556 .

Population stock (number of inhabitants):

1530: No data. The Numeramento da População does not cover localities in Alentejo at the parish level.

1700: No data. Santos (2003, p. 173) considers the Corografia of Costa (1706-1712) unsuitable for the region of Évora.

1720: 252 Santos (2003, pp. 188-9).

1758: 628 Memórias Paroquiais. Cited in Santos (2003, pp. 188-9).

1801: 707 Silveira (2001).

1849: 588 Silveira (2001).

1864: 572 Censo (1868). 
Source for births and deaths: Santos (2003).

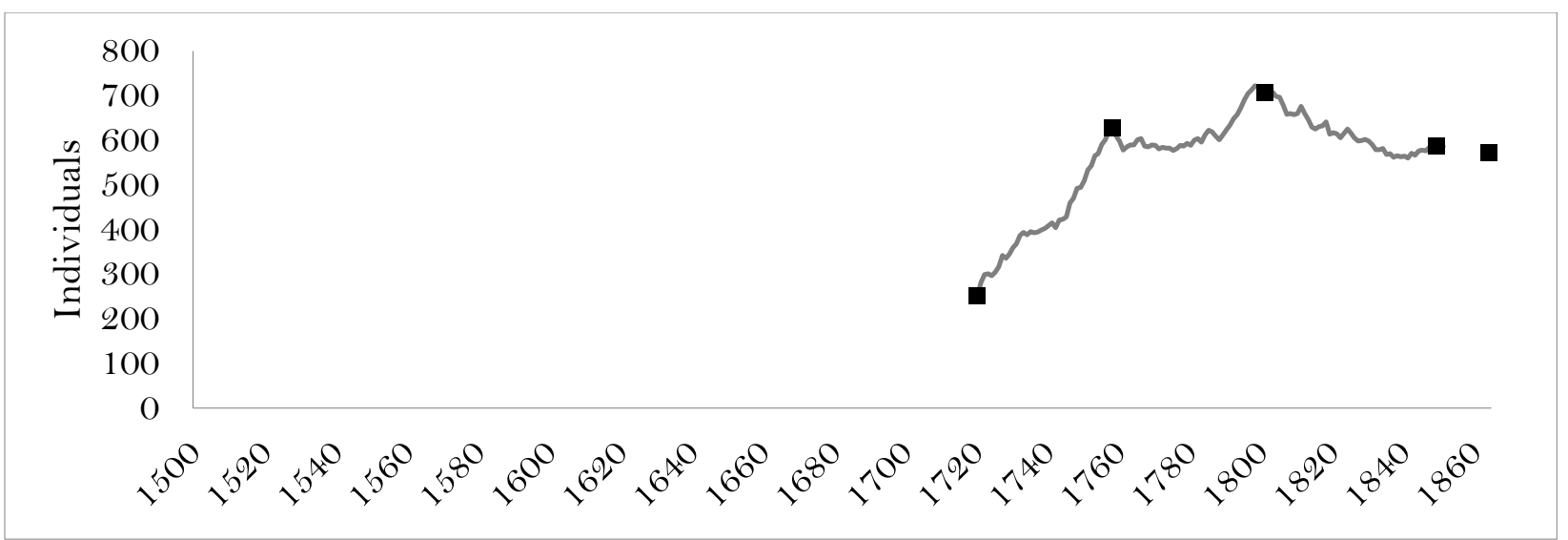

Figure A8. Nossa Senhora da Graça do Divor (Évora)

A9. S. Brás do Regedouro (Évora) (1720-1851)

Location: in the province of Alentejo and the archbishopric of Évora. A small rural parish in the hinterland of the city and municipality of Évora. Presently in the district of Évora, the earliest reference to its parish church goes back to 1536 but its origins are much older.

Population stock (number of inhabitants):

1530: No data. The Numeramento da População does not cover localities in Alentejo at the parish level.

1700: No data. Santos (2003, p. 173) considers the Corografia of Costa (1706-1712) unsuitable for the region of Évora.

1720: 236 Santos (2003, pp. 188-9).

1758: 272 Memórias Paroquiais. Cited in Santos (2003, pp. 188-9).

1801: 178 Silveira (2001).

1849: 176 Silveira (2001).

1864: 186 Censo (1868).

Source for births and deaths: Santos (2003). 


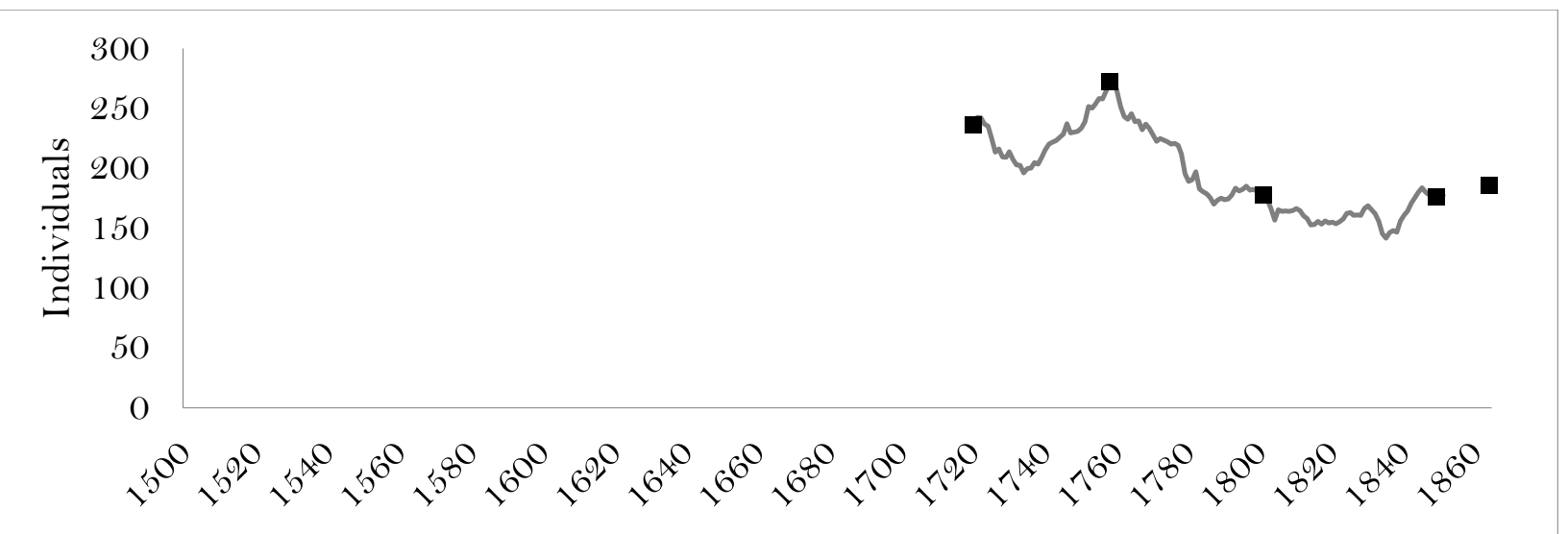

Figure A9. S. Brás do Regedouro (Évora)

A10. Torre de Coelheiros (Évora) (1720-1851)

Location: the province of Alentejo and the archbishopric of Évora. A rural parish in the hinterland of the city and municipality of Évora. Presently in the district of Évora, this parish was instituted in 1535.

Population stock (number of inhabitants):

1530: No data. The Numeramento da População does not cover localities in Alentejo at the parish level.

1700: No data available. Santos (2003, p. 173) considers the Corografia of Costa (1706-1712) unsuitable for the region of Évora.

1720: 256 Santos (2003, pp. 188-9).

1758: 300 Memórias Paroquiais. Cited in Santos (2003, pp.188-9).

1801: 327 Silveira (2001).

1849: 284 Silveira (2001).

1864: 1,054 Censo (1868).

Source for births and deaths: Santos (2003). 


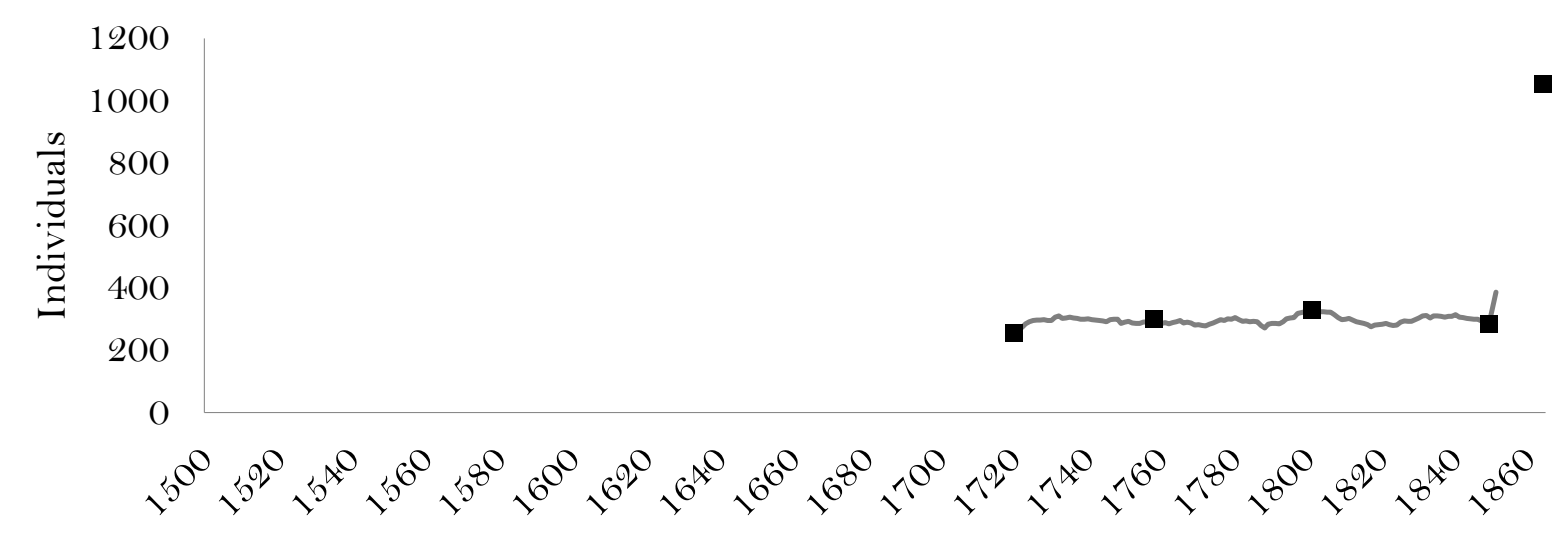

Figure A10. Torre de Coelheiros (Évora)

A11. Monte do Trigo (Évora) (1720-1851)

Location: in the province of Alentejo and the archbishopric of Évora. A rural parish in the municipality of Portel. Presently in the district of Évora, the parish existed in the 16th century though the settlement dates back to the 13th century.

Population stock (number of inhabitants):

1530: No data. The Numeramento da População does not cover localities in Alentejo at the parish level.

1700: No data. Santos (2003, p. 173) considers the Corografia of Costa (1706-1712) unsuitable for the region of Évora.

1720: 432 Santos (2003, pp. 188-9).

1758: 720 Memórias Paroquiais. Cited in Santos (2003, pp. 188-9).

1801: 679 Silveira (2001).

1849: 774 Silveira (2001).

1864: 913 Censo (1868).

Source for births and deaths: Santos (2003). 


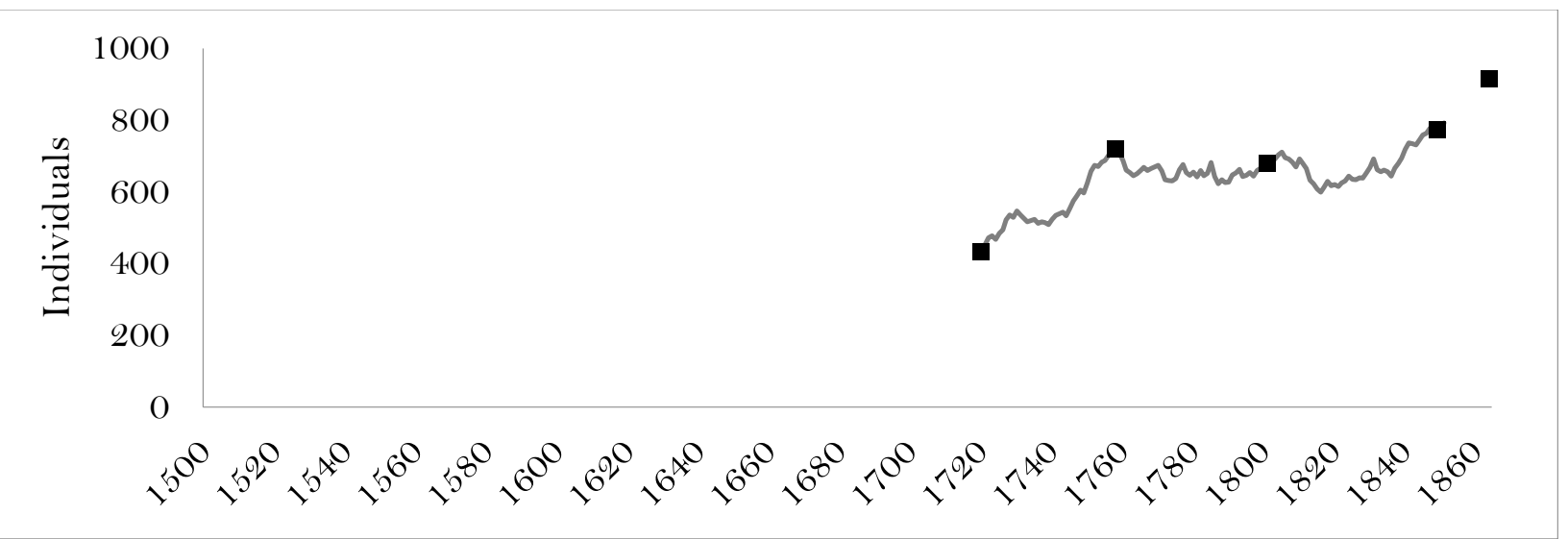

Figure A11. Monte do Trigo (Évora)

A12. Igrejinha (Arraiolos) (1700-1851)

Location: in the province of Alentejo and the archbishopric of Évora. A rural parish in the municipality of Arraiolos, at present it lies in the district of Évora. Its parish church was initially built in the sixteenth century.

Population stock (number of inhabitants):

1530: No data. The Numeramento da População does not cover localities in Alentejo at the parish level.

1700: 200 From Costa (1706-1712) cited by Santos (2003, p.188).

1720: 180 Santos (2003, pp. 188-9).

1758: 524 Memórias Paroquiais, cited in Santos (2003, pp. 188-9).

1801: 743 Silveira (2001).

1849: 807 Silveira (2001).

1864: 918 Censo (1868).

Source for births and deaths: Santos (2003). 


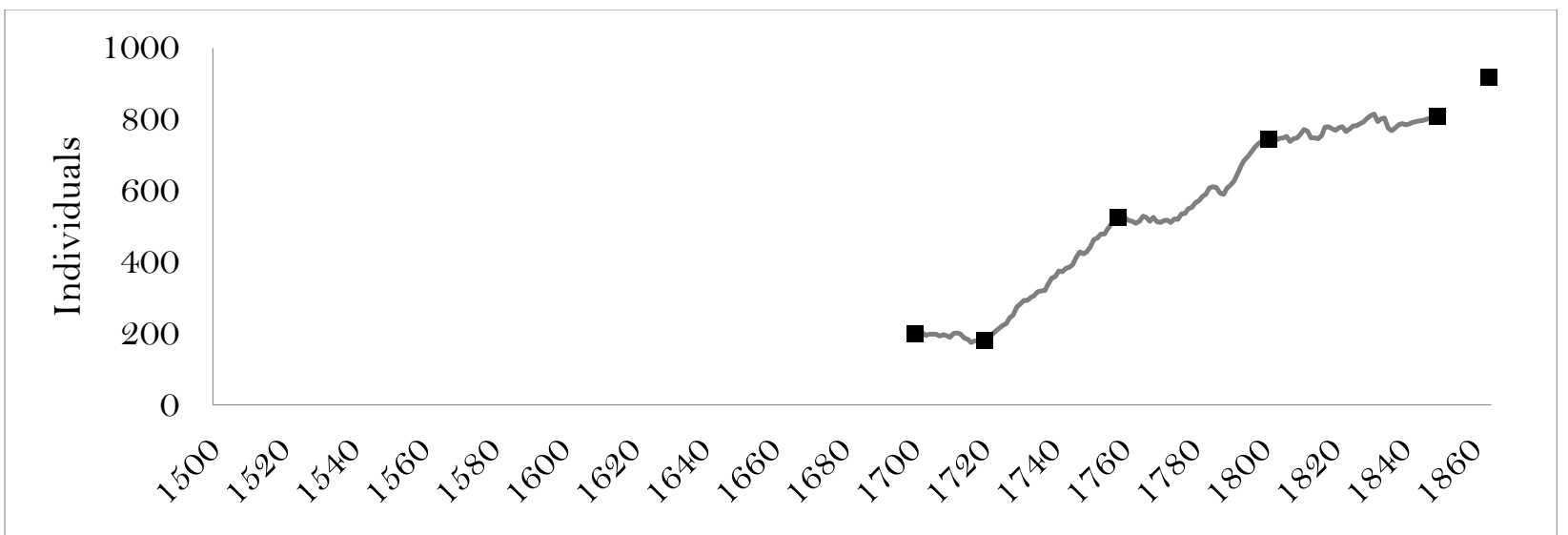

Figure A12. Igrejinha (Arraiolos)

\section{B. Algarve}

\section{B1. Conceição de Tavira (1766-1864)}

Location: the province of Algarve and the bishopric of Faro. A coastal fishing parish in the municipality of Tavira. Presently it lies in the district of Faro. The date of its creation is unknown but the parish was already in existence by 1518 .

Population stock (number of inhabitants):

1530: No data. The Numeramento da População does not cover Algarve.

1600: 600 Pinto (1996, p.17).

1700: No data. No mention in in the Corografia of Costa (1706-12).

1758: 968 Memórias Paroquiais, cited in Pinto (1996, p.17).

1801: 486 Silveira (2001).

1849: 1,040 Silveira (2001).

1864: 1,680 Censo (1868).

Source for births and deaths: Pinto (1996). 


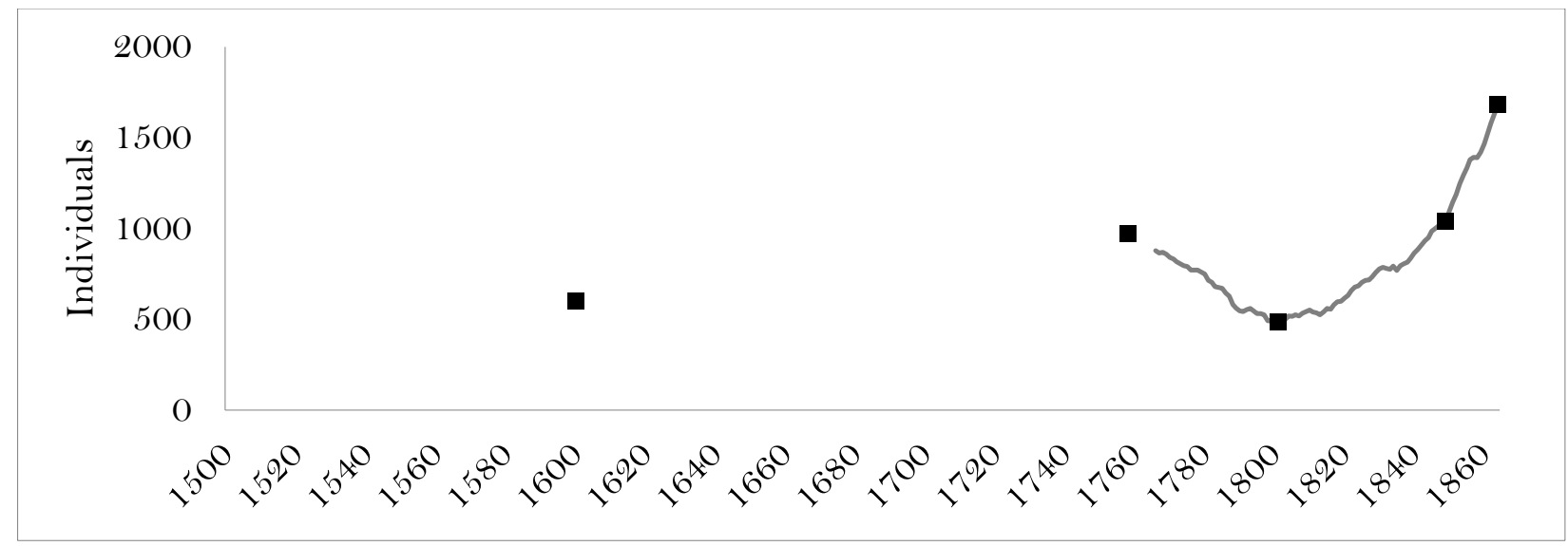

Figure B1. Conceição de Tavira

\section{Beira}

\section{C1. Almalaguez (Coimbra) (1560-1864)}

Location: the province of Beira and the bishopric of Coimbra. A small rural densely-populated parish in the hinterland of the city and municipality of Coimbra. At present, it lies in the district of Coimbra. Originally a Moorish settlement, its earliest traces in Portuguese history date from the $12^{\text {th }}$ century, as an outpost of the Reconquista.

Population stock (number of inhabitants):

1530: 216. From the Numeramento da População, cited in Oliveira (1972).

1607: 400, a fiscal indicator suggested by Oliveira (1972).55

1700: 544 From Costa (1706-12).

1758: 1,800. From Memórias Paroquiais, cited in Capela (2011).

1801: 1,962 Silveira (2001).

1849: 2,005 Silveira (2001).

1864: 2,176 Censo (1868).

55 "Tax paying families are not synonymous with hearths [... ] but they come close" (Oliveira 1972, p.180). 
Source for births and deaths: Arquivo da Universidade de Coimbra, Registos Paroquiais, Almalaguês: Baptismos - Livros 1-5; Óbitos - Livro 1; Mistos - Livro 1.

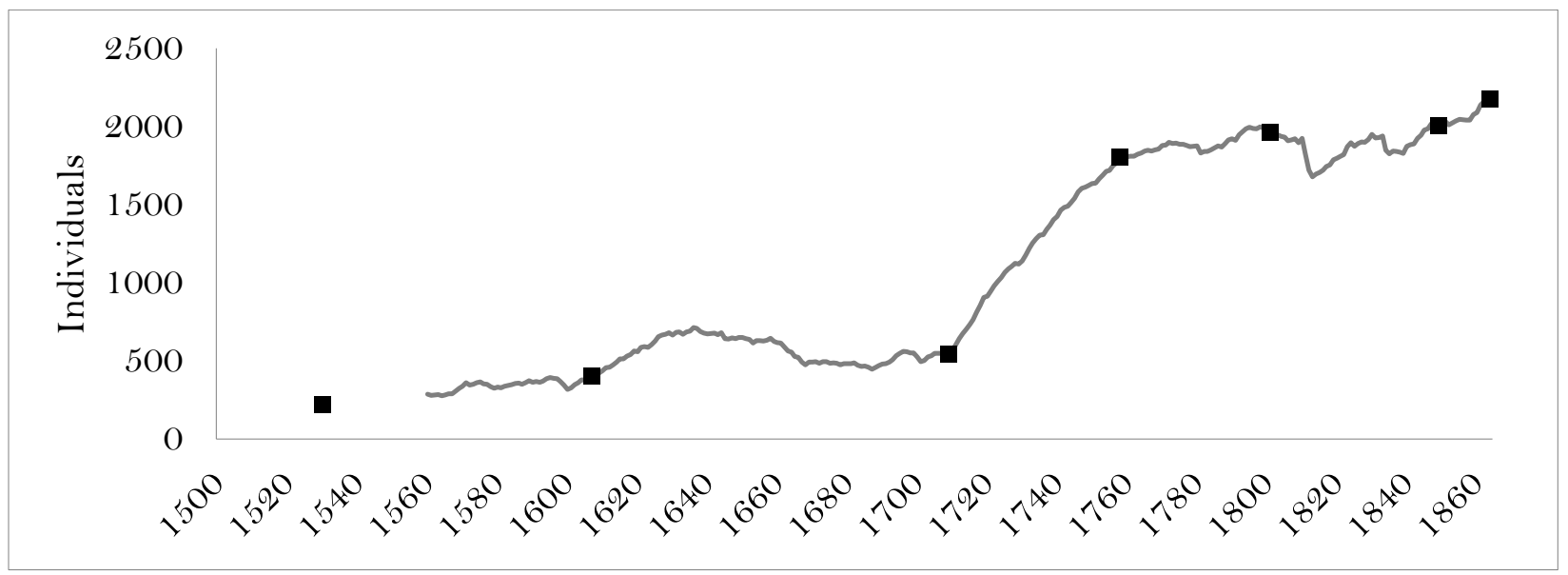

Figure C1. Almalaguez

\section{C2. Vera Cruz (Aveiro) (1695-1801)}

Location: the province of Beira and the bishopric of Aveiro, after the latter was broken off from the bishopric of Coimbra in 1776. One of the urban parishes of the city and municipality of Aveiro. It presently lies in the district of Aveiro. It came into existence in 1572 when the parish of S. Miguel, which previously occupied the whole city, was divided into four smaller parishes.

Population stock (number of inhabitants):

1530: no data. Santa Cruz did not exist at this date.

1685: 1,820 Amorim (1996).

1700: no data available in Costa (1706-1712).

172 1: 1,540 Amorim (1996).

1775: 1,360 Amorim (1996).

1801: 929 Silveira (2001). 
1849: by amalgation, Vera Cruz no longer in existence.

1864: by amalgation, Vera Cruz no longer in existence.

Source for births and deaths: Amorim (1996).

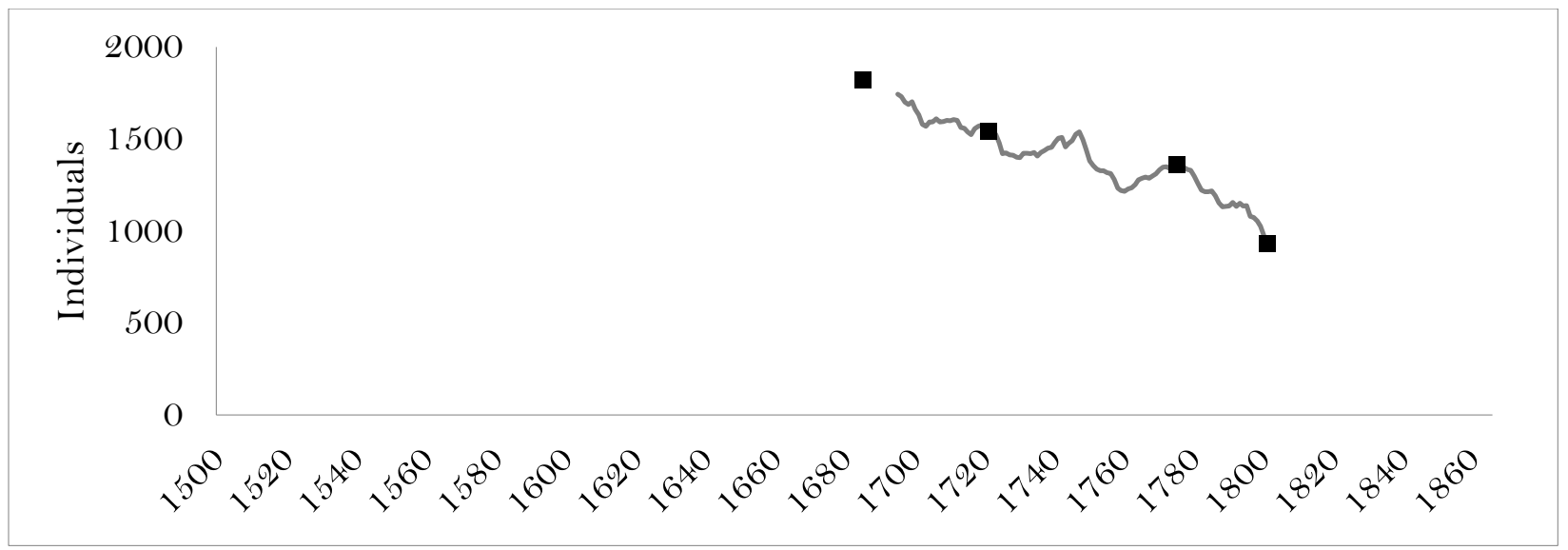

Figure C2. Vera Cruz (Aveiro)

C3. S. Miguel (Aveiro) (1695-1801)

Location: the province of Beira and the bishopric of Coimbra until 1776, and after that the bishopric of Aveiro. It was the single urban parish of the city and municipality of Aveiro, dating back to the $11^{\text {th }}$ century and the Reconquista. It was divided into four smaller urban parishes in 1572 - Vera Cruz, Apresentação, Espírito Santo and S. Miguel, which together constituted the city of Aveiro. In 1835, it ceased to have a separate existence and joined the parish of Esprito Santo to form that of Glória.

Population stock (number of inhabitants):

1530: No data. S. Miguel at this date does not correspond to its later post1572 form.

1685: 1,800 Amorim (1996).

1700: no data available in Costa (1706-1712).

172 1: 1,480 Amorim (1996).

1775: 964 Amorim (1996). 
1801: 895 Silveira (2001).

1849: by amalgation, $\mathrm{S}$. Miguel no longer in existence.

1864: by amalgation, S. Miguel no longer in existence.

Source for births and deaths: Amorim (1996).

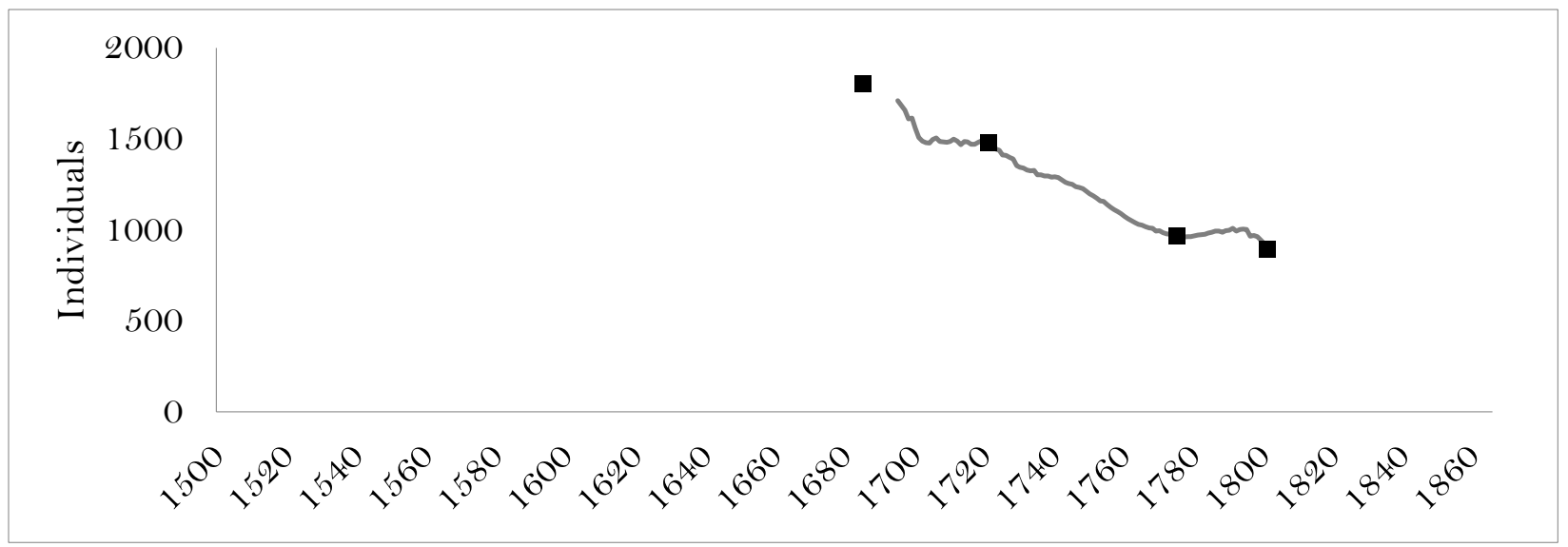

Figure C3. S. Miguel (Aveiro)

C4. Apresentação (Aveiro) (1695-1801)

Location: the province of Beira and the bishopric of Aveiro, after the latter was broken off in 1776 from the bishopric of Coimbra. One of the urban parishes in the centre of the city and municipality of Aveiro. At present it lies in the district of Aveiro. It came into existence in 1572 when the parish of S. Miguel, which previously comprised the whole city, was divided into four parishes.

Population stock (number of inhabitants):

1530: No data. Apresentação did not exist then.

1685: 1,480 Amorim (1996).

1700: no data available in Costa (1706-1712).

1721: 956 Amorim (1996). 
1775: 888 Amorim (1996).

1801: 882 Silveira (2001).

1849: by amalgation, Apresentação no longer in existence.

1864: by amalgation, Apresentação no longer in existence.

Source for births and deaths: Amorim (1996).

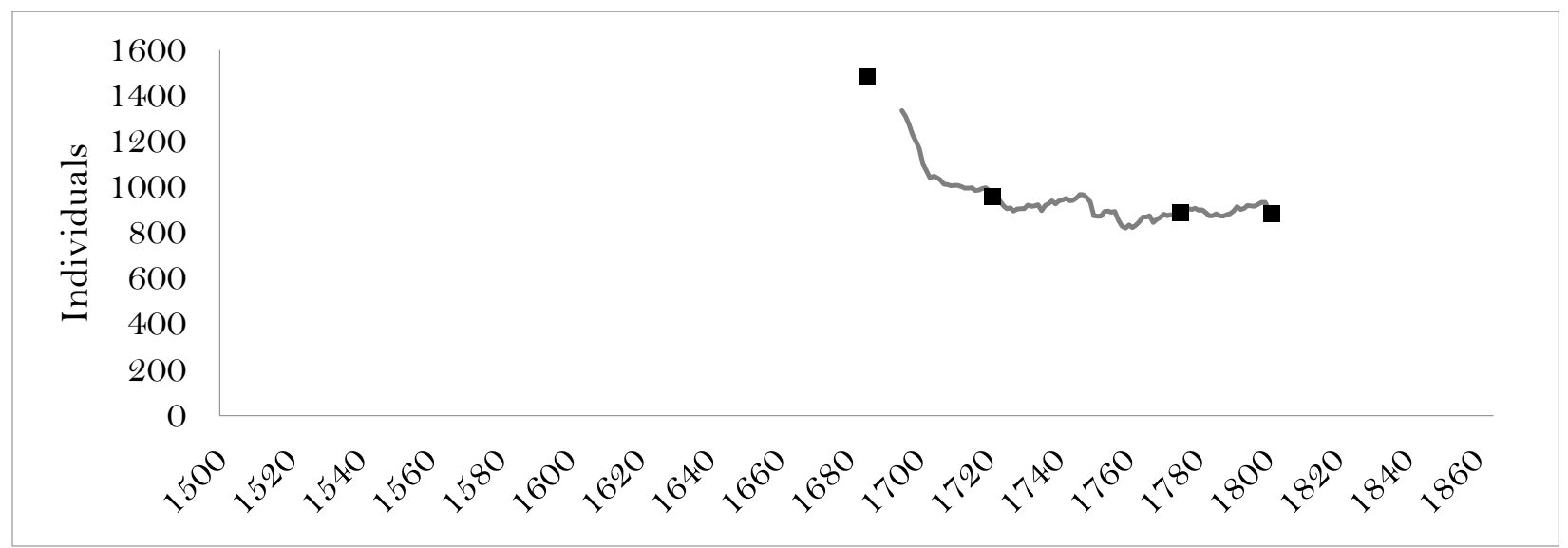

Figure C4. Apresentação (Aveiro)

\section{C5. Espírito Santo (Aveiro) (1695-1801)}

Location: the province of Beira and the bishopric of Aveiro, after the latter was broken off in 1776 from the archbishopric of Coimbra. One of the four urban parishes in the city and municipality of Aveiro. Presently, it lies in the district of Aveiro. It came into existence in 1572 when the parish of S. Miguel, which previously occupied the whole city, was divided into four smaller parishes.

Population stock (number of inhabitants):

1530: No data. Espírito Santo did not exist yet.

1685: 1,500 Amorim (1996).

1700 no data available in Costa (1706-1712).

172 1: 1,480 Amorim (1996). 
1775: 1,452 Amorim (1996).

1801: 1,162 Silveira (2001).

1849: by amalgation, Espírito Santo no longer in existence.

1864: by amalgation, Espírito Santo no longer in existence.

Source for births and deaths: Amorim (1996).

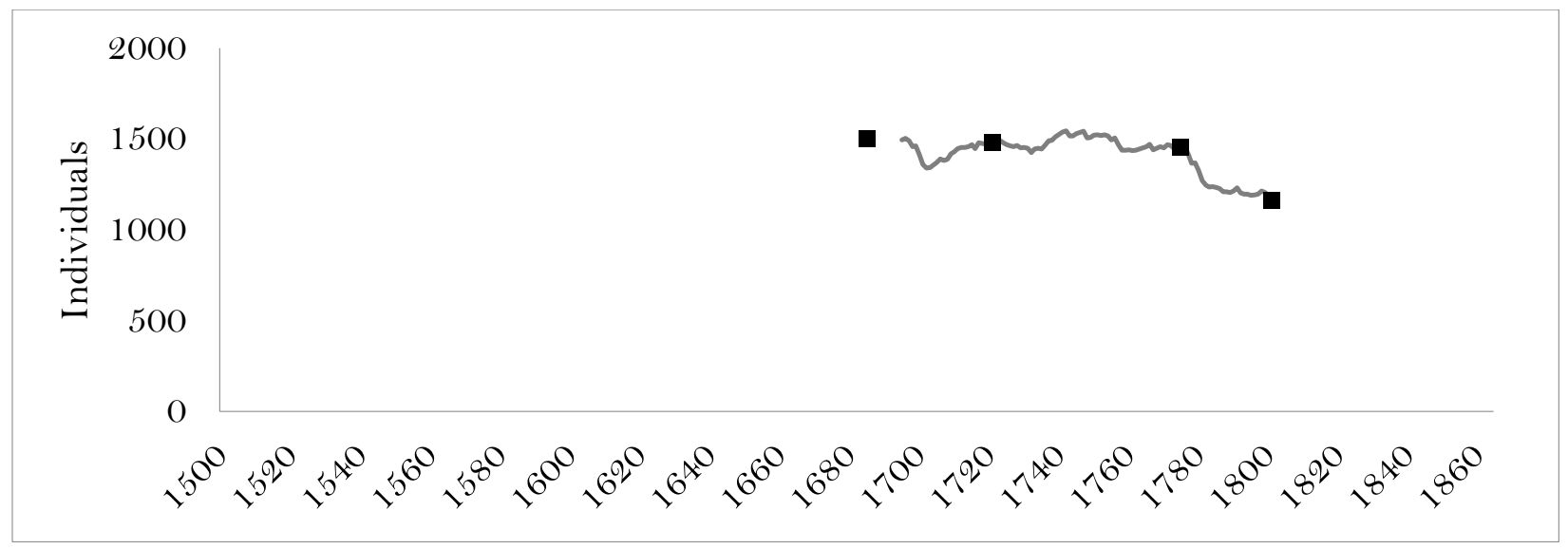

Figure C5. Espirito Santo (Aveiro)

C6. S. Bartolomeu (Coimbra) (1610-1709)

Location: in the province of Beira and the bishopric of Coimbra. One of the eight urban parishes of the city and municipality of Coimbra. Presently, it lies in the district of Coimbra. The earliest reference to the parish church dates from the mid $10^{\text {th }}$ century.

Population stock (number of inhabitants):

1530: No data. Not available in the Numeramento da População.

1610: 1,166 a fiscal indicator suggested by Oliveira (1972).

1700: No data. (Costa 1706-12).

1758: 1,552 Memórias Paroquiais, cited in Capela (2011).

1801: 1,453 Silveira (2001). 
1849: 1,224 Silveira (2001).

1864: 3,293 Censo (1868).

Source for births and deaths: Data kindly supplied by António de Oliveira.

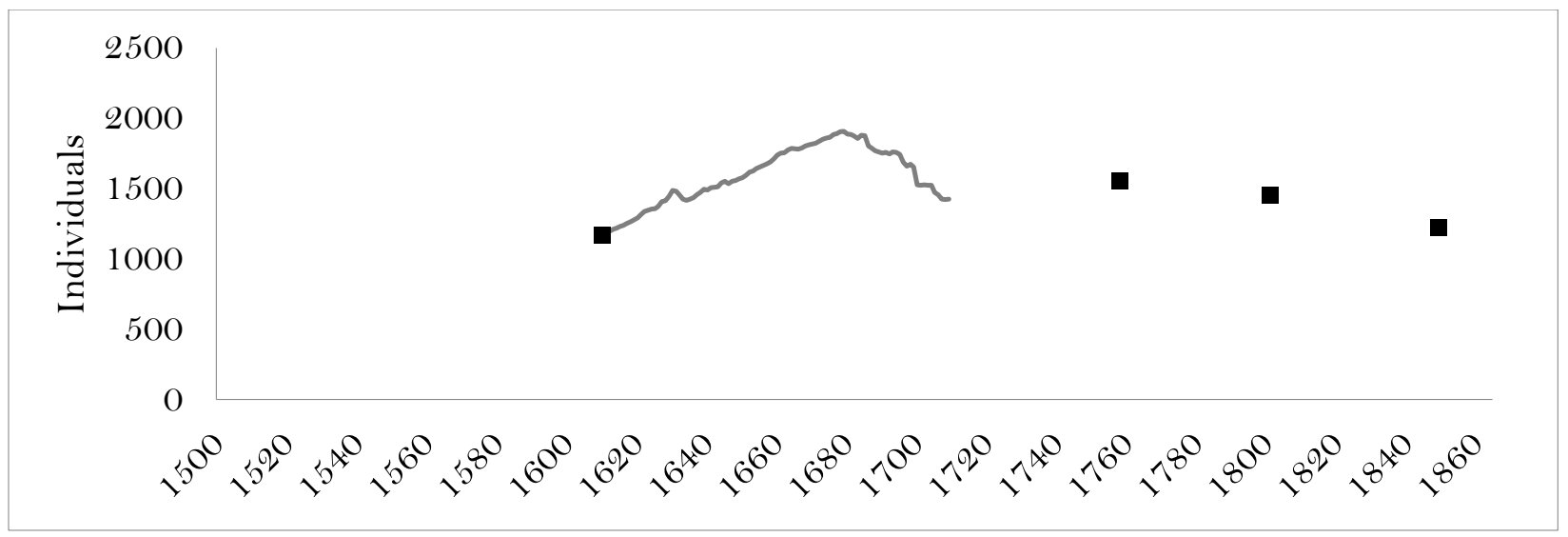

Figure C6. S. Bartolomeu (Coimbra)

C7. S. Cruz (Coimbra) (1607-1709)

Location: The province of Beira and the bishopric of Coimbra. One of the eight urban parishes of the city and municipality of Coimbra. Presently, it lies in the district of Coimbra. The earliest reference to the church dates from the mid $10^{\text {th }}$ century but the parish was instituted in only 1131 , when the great monastery of Santa Cruz was built.

Population stock (number of inhabitants):

1530: No data. Not available in the Numeramento da População.

1607: 859 A fiscal indicator suggested by Oliveira (1972).

1700 No data. (Costa 1706-12).

1758: 912 Memórias Paroquiais, cited in Capela (2011).

1801: 2,353 Silveira (2001)

1849: 1,860 Silveira (2001).

1864: 3,213 Censo (1868). 
Source for births and deaths: Data kindly supplied by António de Oliveira.

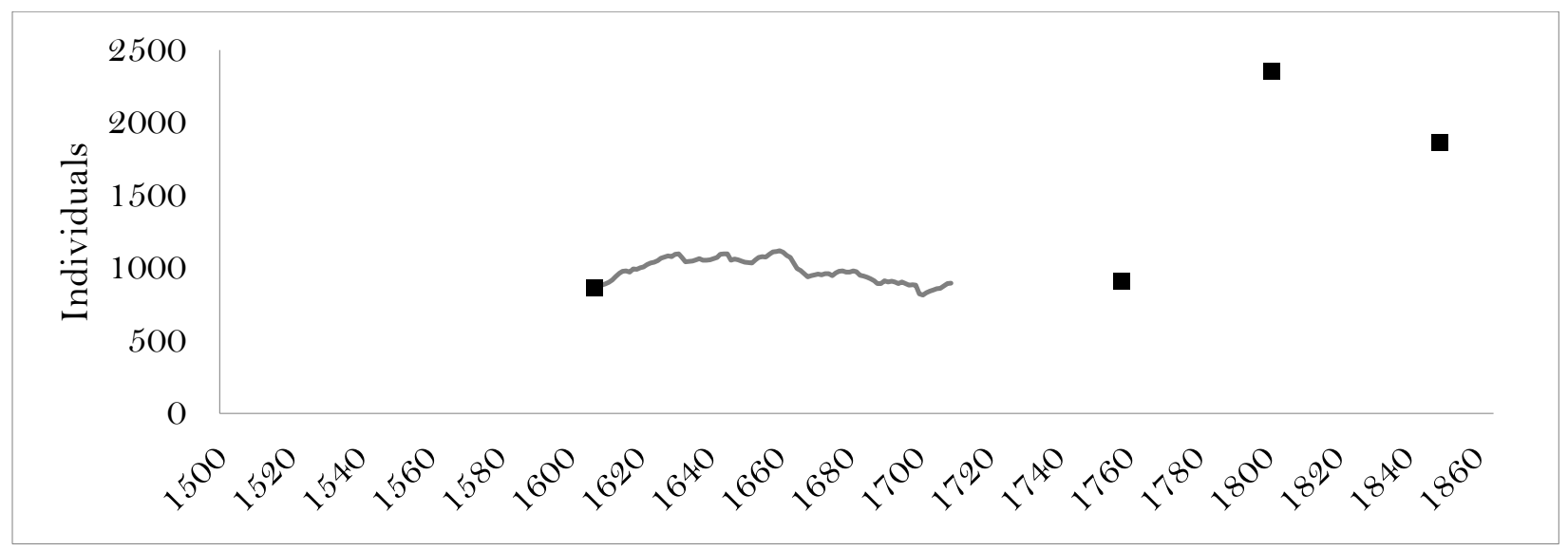

Figure C7. S. Cruz (Coimbra)

\section{C8. Sé (Coimbra) (1610-1709)}

Location: The province of Beira and the bishopric of Coimbra. The leading parish of the eight urban parishes of the city and the municipality of Coimbra. Presently, it lies in the district of Coimbra. The See of Coimbra was built some time after the year 1139 .

Population stock (number of inhabitants):

1530: No data. Not available in the Numeramento da População.

1610: 463 a fiscal indicator suggested by Oliveira (1972).

1700: Not available (Costa 1706-12).

1758: 3,168 Memórias Paroquiais cited in Capela (2011).

1801: 2,995 Silveira (2001).

1849: Not available. Silveira (2001).

1864: 3,499 Censo (1868).

Source for births and deaths: Data kindly supplied by António de Oliveira 


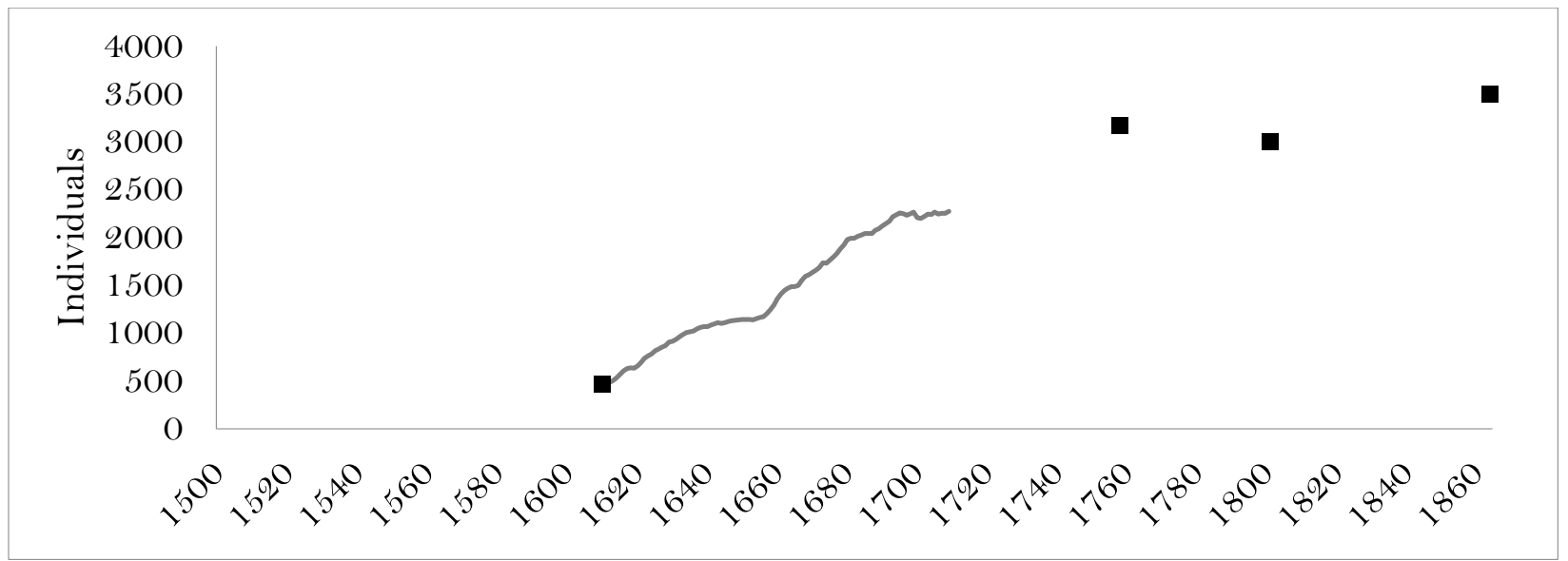

Figure C8. Sé (Coimbra)

C9. Santiago (Coimbra) (1709-1610)

Location: The province of Beira and the bishopric of Coimbra. One of the eight urban parishes of the city and municipality of Coimbra. Presently, it lies in the district of Coimbra. The parish church was built circa 1200.

Stock of population (number of inhabitants):

1530: No data. Not available in the Numeramento da População.

1610: 1,312 A fiscal indicator suggested by Oliveira (1972).

1700: No data. (Costa 1706-12).

1758: 1,200 Memórias Paroquiais, cited in Capela (2011).

1801: 1,793 Silveira (2001).

1849: 1,461 Silveira (2001).

1864: 3,449 Censo (1868).

Source for births and deaths: Data kindly supplied by António de Oliveira. 


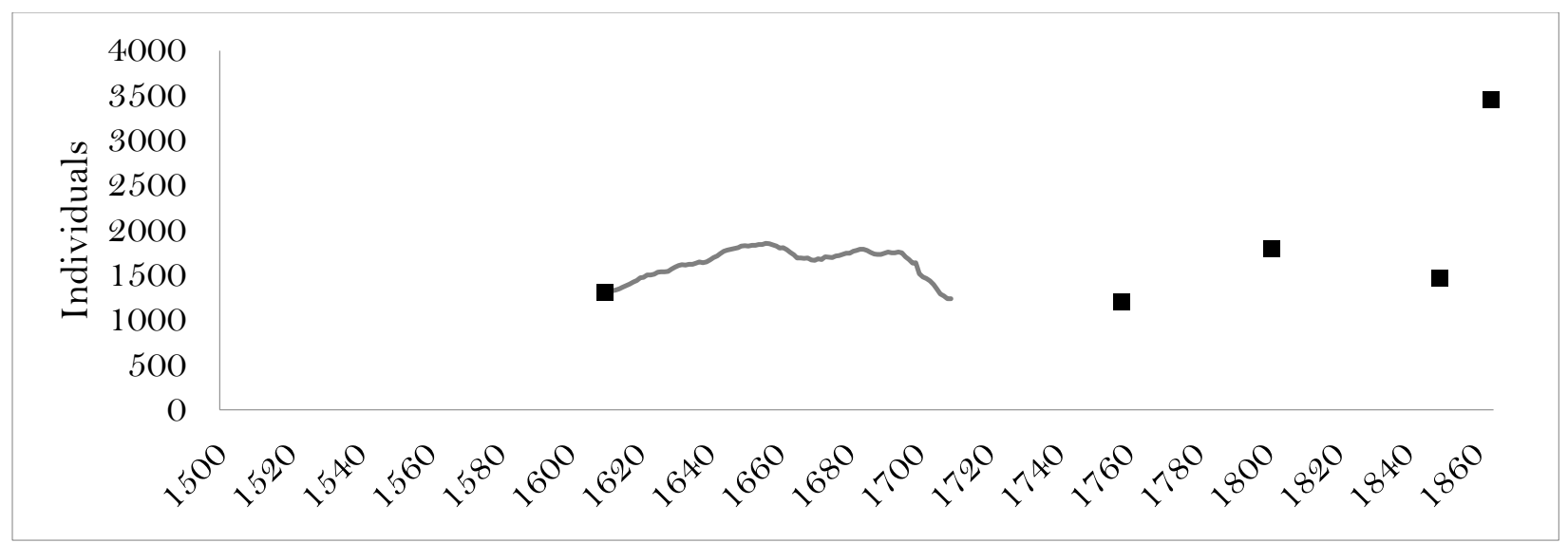

Figure C9. Santiago (Coimbra)

\section{C10. Santa Justa (Coimbra) (1610-1709)}

Location: the province of Beira and the bishopric of Coimbra. One of the eight urban parishes of the city and municipality of Coimbra. Presently, it lies in the district of Coimbra. The parish was founded sometime in the $11^{\text {th }}$ century.

Population Stock (number of inhabitants inhabitants):

1530 No data. Not available in the Numeramento da População,.

1610: 859 a fiscal indicator suggested by Oliveira (1972).

1700: No data. (Costa 1706-12).

1758: 1,400 Memórias Paroquiais cited in Capela (2011).

1801: 1,461 Silveira (2001).

1849: 1,246 Silveira (2001).

1864: Not shown in Censo (1868).

Source for births and deaths: Data kindly supplied by António de Oliveira. 


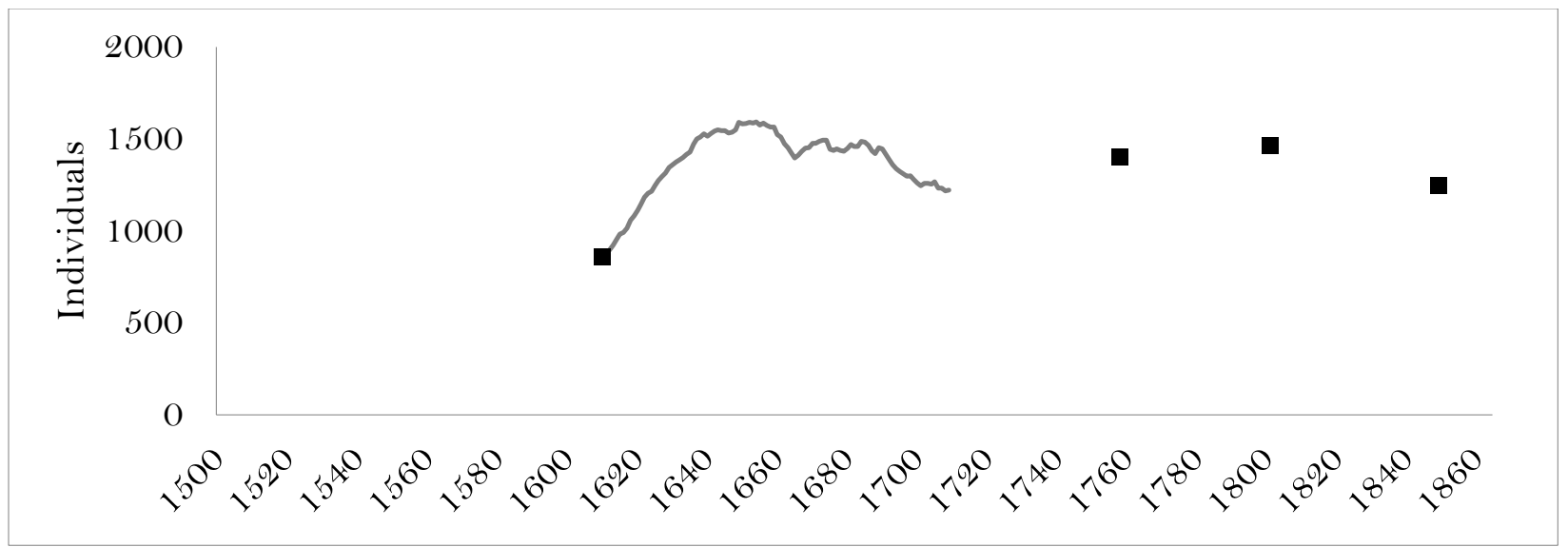

Figure C10. S. Justa (Coimbra)

C11. S. Pedro (Coimbra) (1610-1709)

Location: The province of Beira and the bishopric of Coimbra. One of the eight urban parishes of the city and municipality of Coimbra. Presently, it lies in the district of Coimbra. The earliest reference to its parish church dates from the mid $10^{\text {th }}$ century. The parish was founded in 1131 .

Population stock (number of inhabitants):

1530: No data available in the Numeramento da População.

1610: 412 A fiscal indicator suggested by Oliveira (1972).

1700: No data (Costa 1706-12).

1758: 1,652 Memórias Paroquiais, data in Capela (2011).

1801: 2,631 Silveira (2001).

1849: 2,473 Silveira (2001).

1864: This parish merged into another in 1855 .

Source for births and deaths: Data kindly supplied by António de Oliveira. 


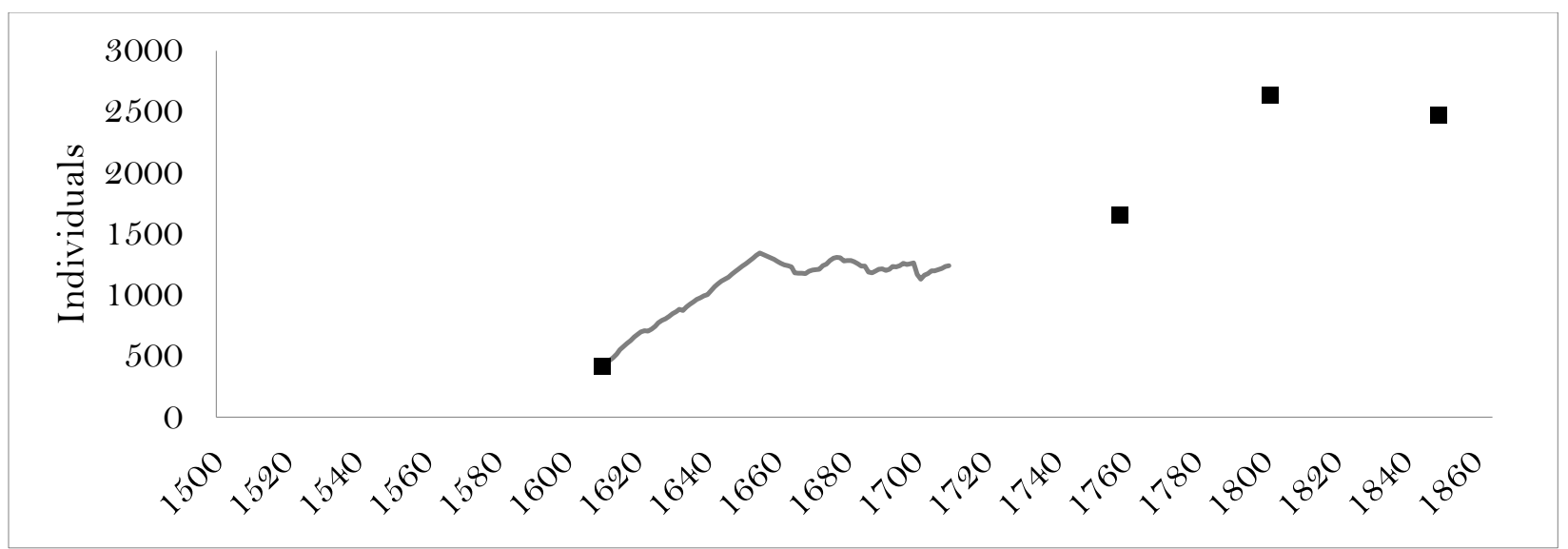

Figure C1 1. S. Pedro (Coimbra)

C12. Nossa Senhora da Graça de Bobadela (Coimbra) (1530-1864)

Location: In the province of Beira and in the bishopric of Coimbra. A small rural parish in the municipality of Oliveira do Hospital. Presently, it lies in the district of Coimbra. It received its municipal charter in 1256 and lost this status in 1836 .

Population stock (number of inhabitants):

1530: 504 From Numeramento da População, cited in Colaço (1934).

1700: 400 Costa (1706-12).

1758: 408 Memórias Paroquiais, cited in Capela (2011).

1801: 634 Silveira (2001).

1849: 888 Silveira (2001).

1864: 848 Censo 1868).

Source for births and deaths: Arquivo Distrital de Lisboa: Bobadela - B1 to $\mathrm{B} 3$ (births), $\mathrm{O} 1$ to $\mathrm{O} 3$ (deaths) and $\mathrm{M} 1$ to $\mathrm{M} 2$ (mixed registers). 


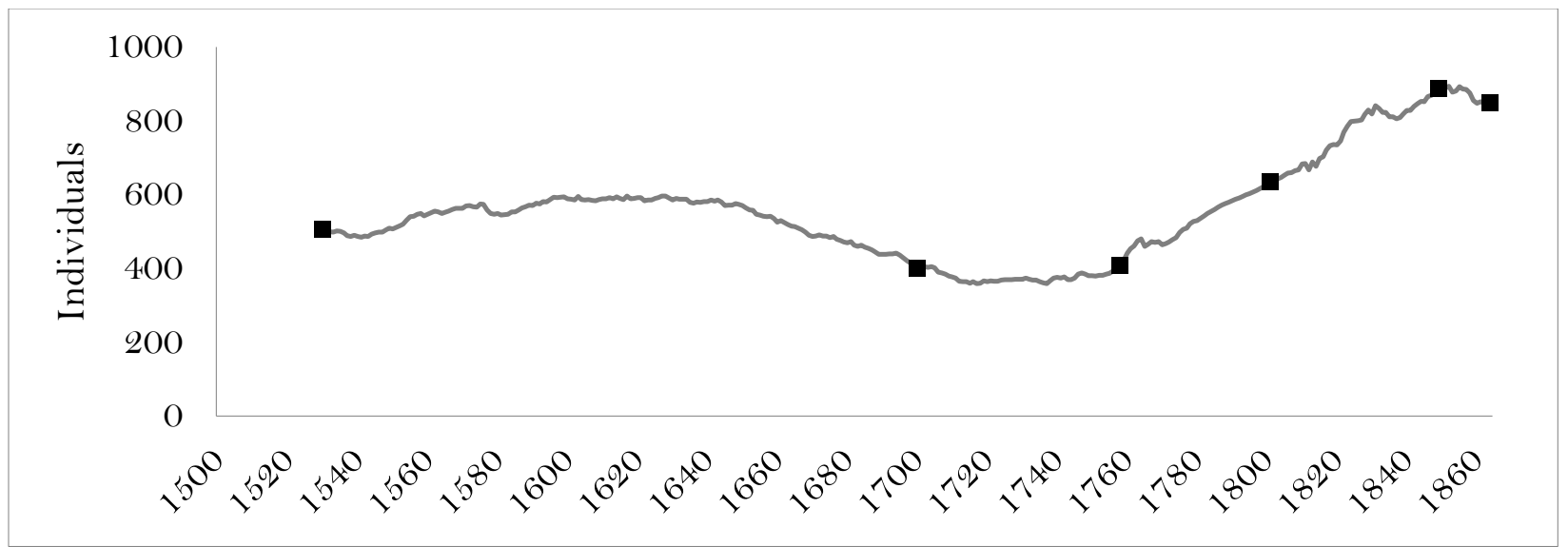

Figure C12. Bobadela (Coimbra)

C13.Nossa Senhora da Conceição de Lagares (Coimbra) (1554-1864)

Location: the province of Beira and the bishopric of Coimbra. A small rural parish in the hinterland of the city and municipality of Coimbra, which presently lies in the district of Coimbra. It was given a municipal charter in 1514 but there is no indication as to when the parish came into existence.

Population stock (number of inhabitants):

1530: 296 From the Numeramento da População, cited in Colaço (1934).

1700: 800 From Costa (1706-12).

1758: 400 Memórias Paroquiais, cited in Capela (2011).

1801: 635 Silveira (2001).

1849: 1,124 Silveira (2001).

1864: 1,264 Censo (1868).

Source for births and deaths: Arquivo Distrital de Lisboa, Lagares, Registos Paroquiais: Baptismos, B1-B4; Óbitos, O1-O8; Mixtos, M1-M2. 


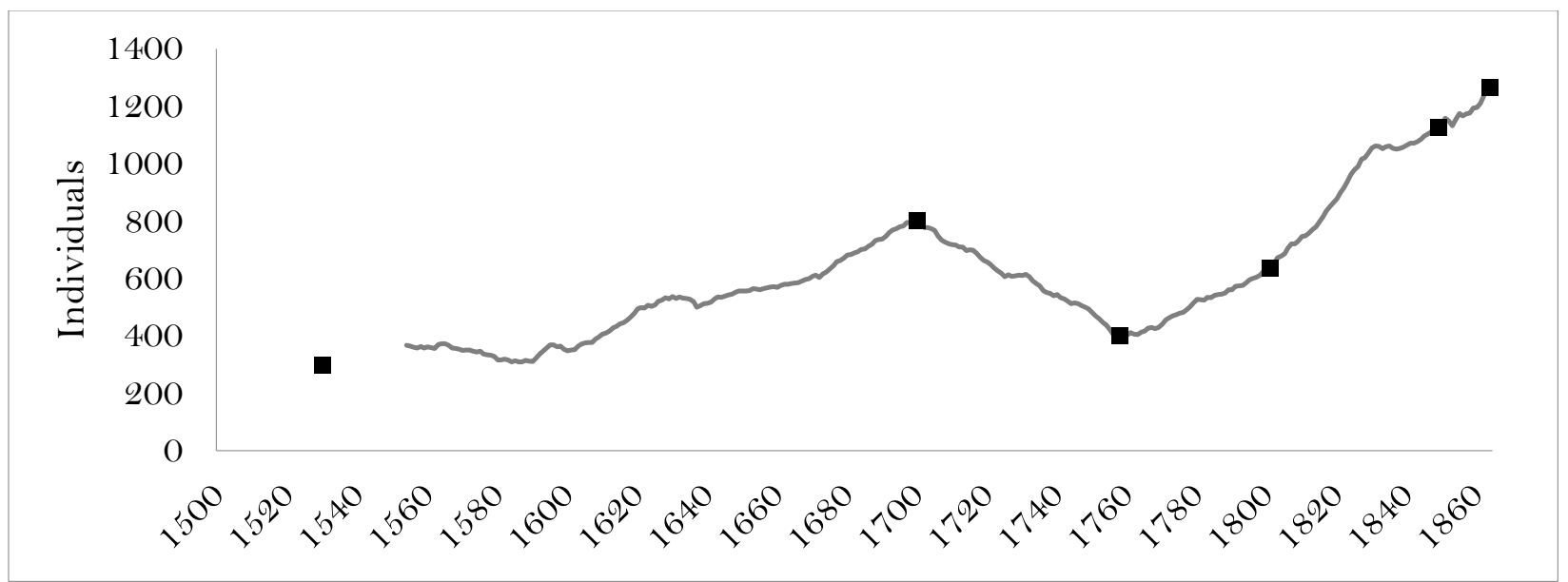

Figure C13. Nossa Senhora da Conceição Lagares (Coimbra)

\section{$\underline{\text { C14. Eixo e Oliveirinha (1666-1864) }}$}

Location: The province of Beira and the bishopric of Coimbra. A rural parish in the hinterland of the city and municipality of Aveiro, which presently lies in the district of Aveiro. While its name appears for the first time in documents in 1050, its municipal charter dates back to 1516 .

Population stock (number of inhabitants):

1530: 436 From Numeramento da População, cited in Colaço (1934).

1700: 1,920 From Costa (1706-12).

1758: 3,000 Memórias Paroquiais cited in Ferreira (2001).

1801: 2,855 Silveira (2001).

1849: 3,197 Silveira (2001).

1864: 3,501 Censo (1868).

Source for births and deaths: Ferreira (2001). 


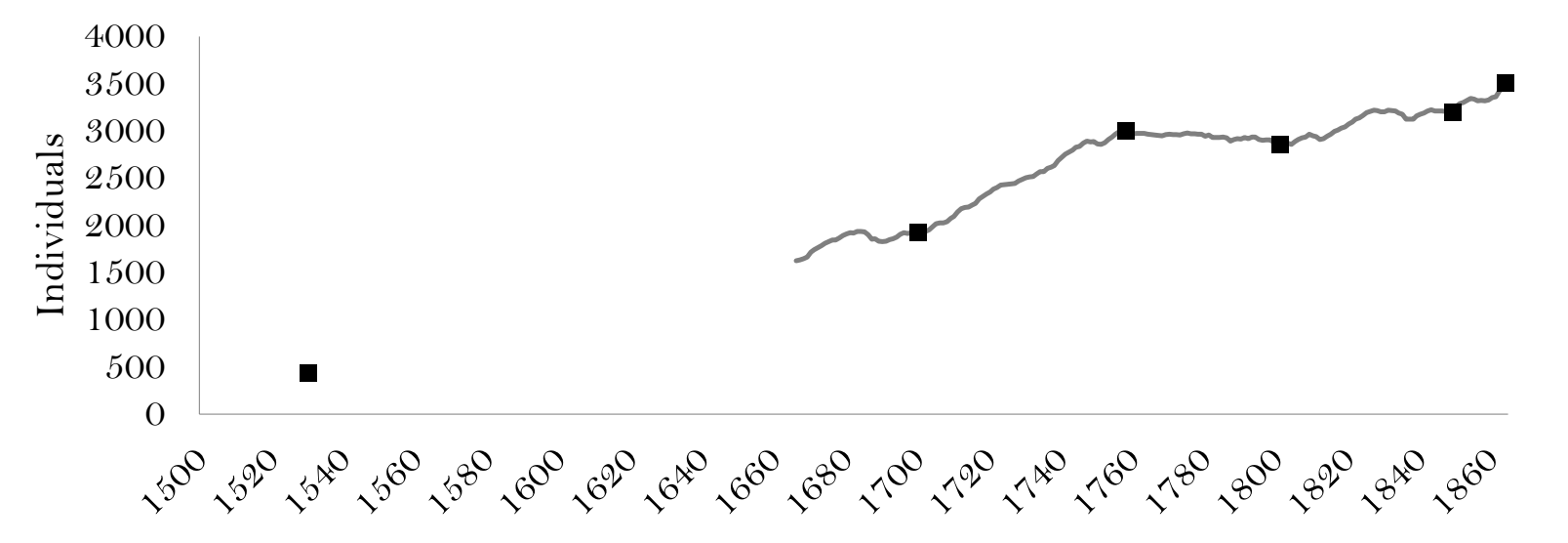

Figure C14. Eixo e Oliveirinha

C15. S. Martinho da Árvore (1616-1686)

Location: The province of Beira and the bishopric of Coimbra. A rural parish in the suburbs of the city and municipality of Coimbra, which presently lies in the district of Coimbra. There is no evidence for the date of the creation of this parish but it is believed to be more than five centuries old.

Population stock (number of inhabitants):

1530: 172 From Numeramento da População, cited in Colaço (1934).

1700: 460 From Costa (1706-12), cited in Gaivão (1974).

1758: 448 Memórias Paroquiais, cited in Gaivão (1974).

1801: 442 Silveira (2001).

1849: 367 Silveira (2001).

1864: 365 Censo (1868).

Source for births and deaths: Gaivão (1974). 


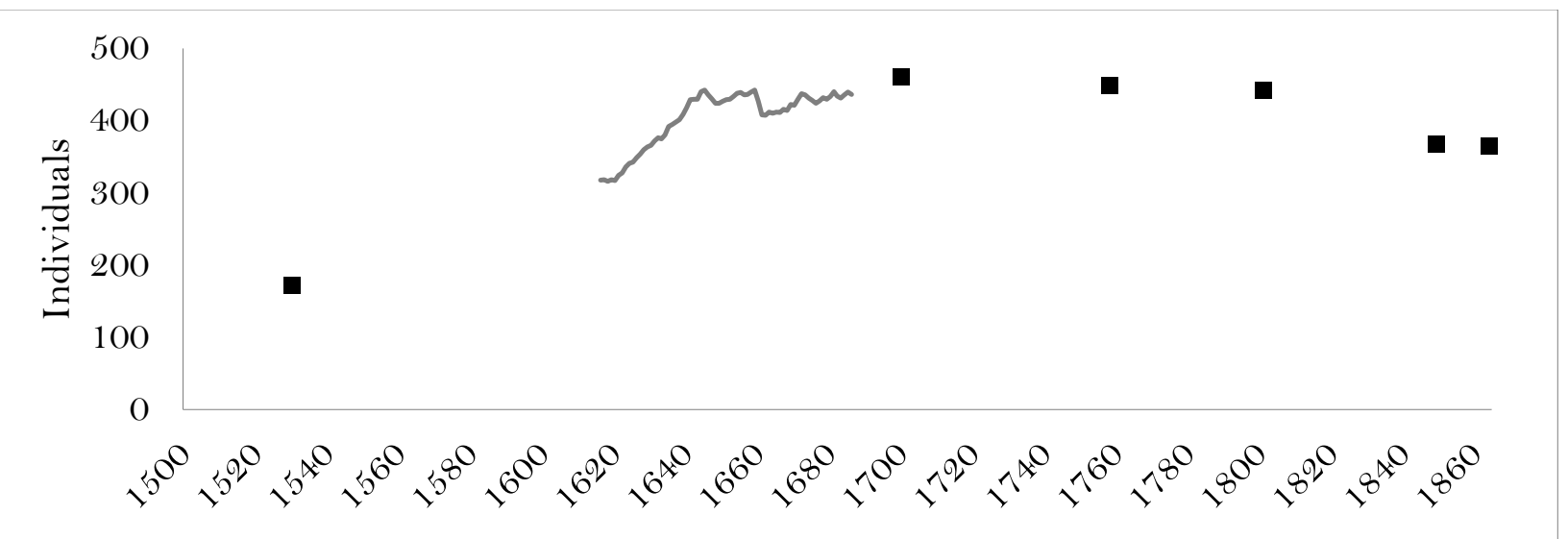

Figure C15. S. Martinho da Árvore

C16. S. João Baptista de Lourosa (Viseu) (1587-1700)

Location: The province of Beira and the bishopric of Viseu. A rural parish in the hinterland of this city. At present, it lies in the district of Viseu. The parish church goes back to 912 and was built by Christians living under Moorish rule.

Population stock (number of inhabitants):

1530: 376 From Numeramento da População, cited in Colaço (1934).

1700: 1,040 From Costa (1706-12).

1758: 1,400 From Memórias Paroquiais, cited in Capela (2010).

1801: 1,459 Silveira (2001).

1849: 2,076 Silveira (2001).

1864: 2,538 Censo (1868).

Source for births and deaths: Oliveira (1990). 


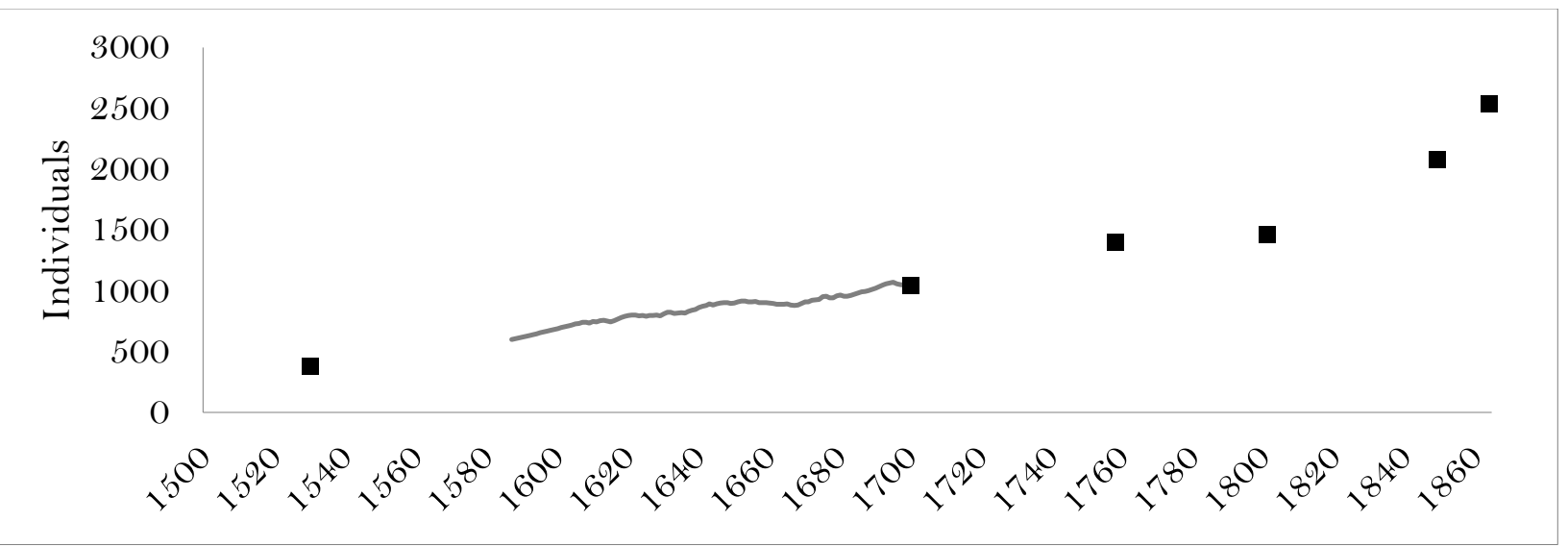

Figure C16. S. João Baptista de Lourosa (Viseu)

\section{$\underline{\text { C17. S. Maria de Tondela (Viseu) (1700-1840) }}$}

Location: The province of Beira and the bishopric of Viseu. A rural parish in the hinterland of Viseu, at present it lies in the district of Viseu. The historical origins of the parish are obscure but go back at least to the 13th century.

Population stock (number of inhabitants):

1530: 52. From the Numeramento da População, cited in Colaço (1934).

1700: 1,080 From Costa (1706-12).

1758: 1,048 From Memórias Paroquiais, cited in Capela (2010).

1801: 1,400 Silveira (2001).

1849: 1,353 Silveira (2001).

1864: 1,682 Censo (1868).

Source for births and deaths: Oliveira (2002). 


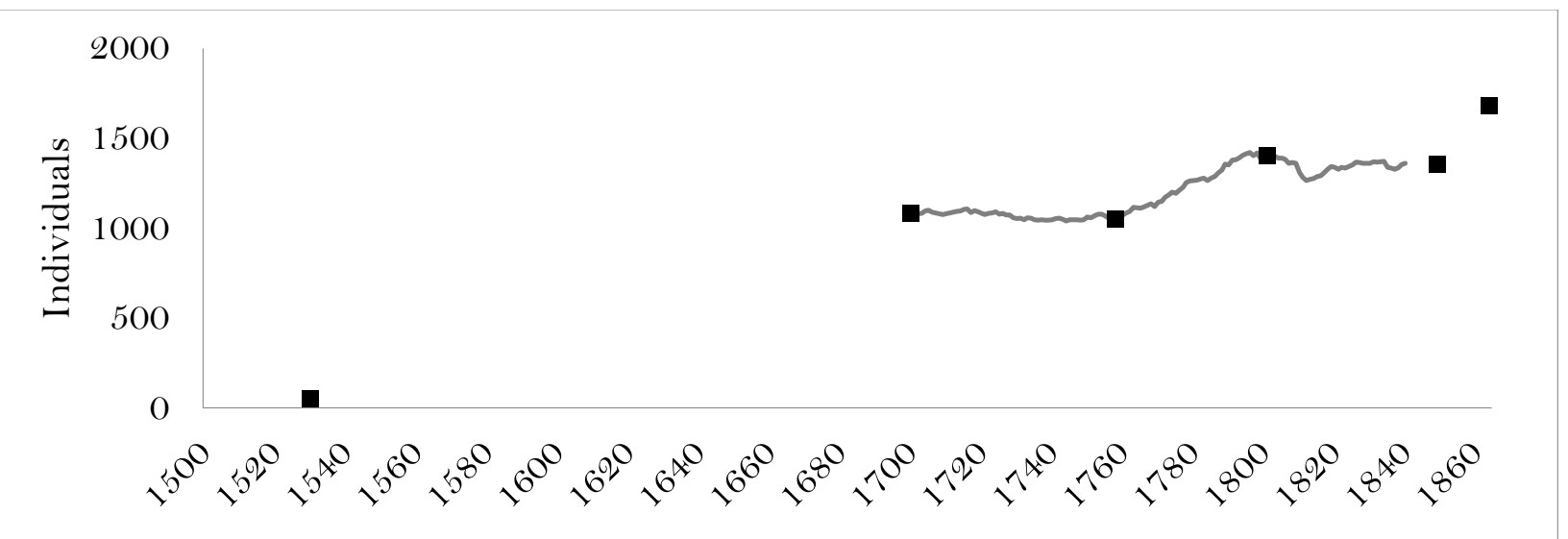

Figure C17. S. Maria de Tondela (Viseu)

C18. S. Pedro do Sul (Viseu) (1700-1840)

Location: The province of Beira and the bishopric of Viseu. A rural parish in the hinterland of this city, with celebrated thermal springs, it presently lies in the district of Viseu. Its parish church existed already between 1092 and 1098. It received its municipal charter in 1152 .

Population stock (number of inhabitants):

1530: 624 From the Numeramento da População, cited in Colaço (1934).

1700: 1,320 From Costa (1706-12).

1758: 1,284 From Memórias Paroquiais, cited in Capela (2010).

1801: 1,967 Silveira (2001).

1849: 1,860 Silveira (2001).

1864: 2,440 Censo (1868).

Source for births and deaths: Oliveira (2002). 


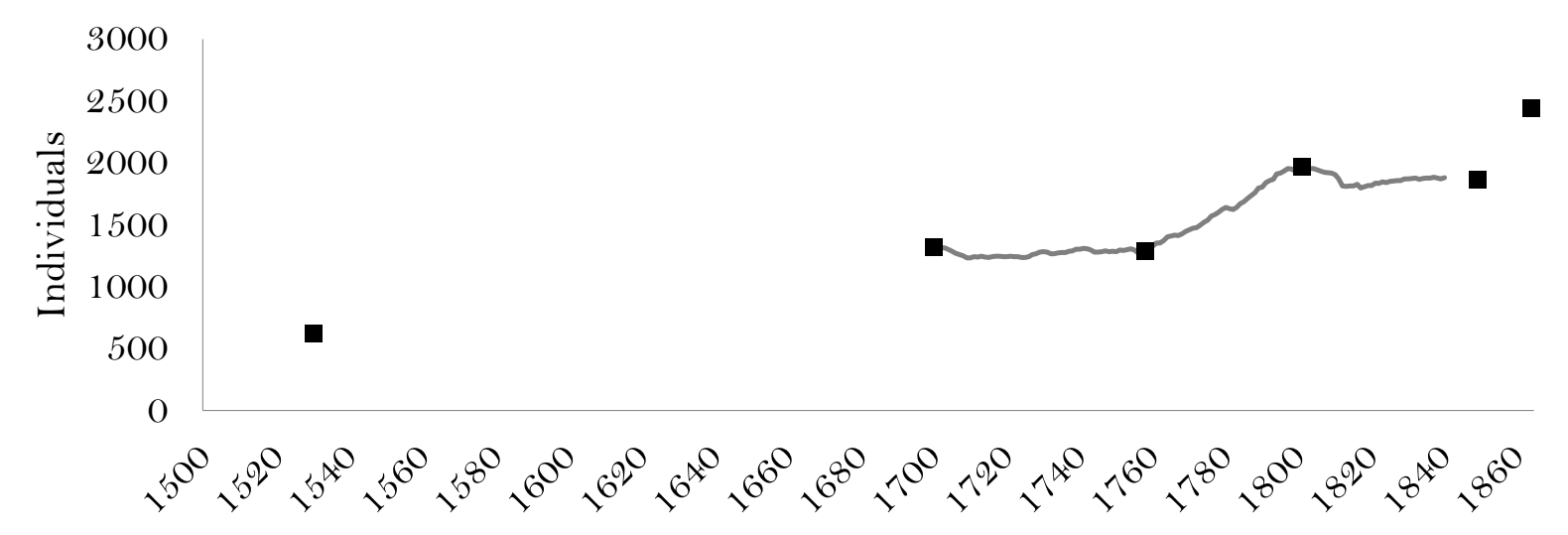

Figure C18. S. Pedro do Sul (Viseu)

$\underline{\text { C19. S. Julião de Mangualde (Viseu) (1700-1840) }}$

Location: In the province of Beira and bishopric of Viseu. A rural parish in the hinterland of this city, formerly known as Zurara or Azurara da Beira, which presently lies in the district of Viseu. It received its first municipal charter in 1102 .

Population stock (number of inhabitants):

1530: 148 From Numeramento da População, cited in Colaço (1934).

1700: 1,840 From Costa (1706-12).

1758: 2,036 From Memórias Paroquiais, cited in Capela (2010).

1801: 2,754 Silveira (2001).

1849: 3,154 Silveira (2001).

1864: 4,162 Censo (1868).

Source for births and deaths: Oliveira (2002). 


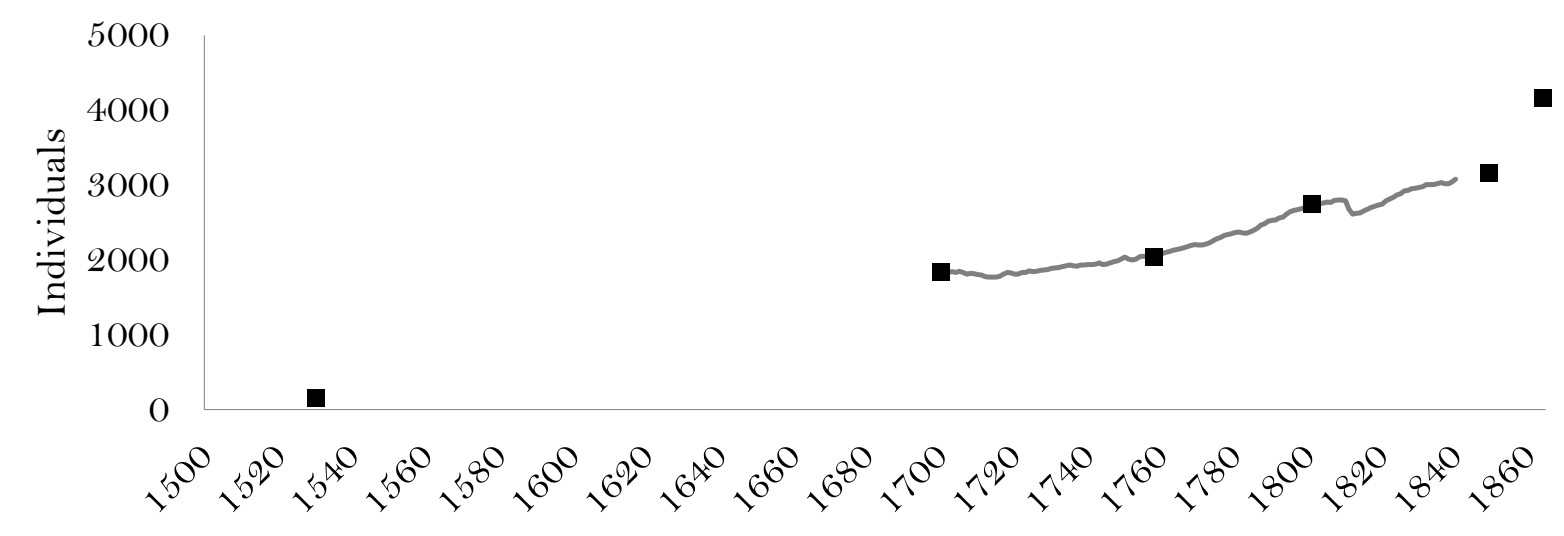

Figure C19. S. Julião de Mangualde (Viseu)

C20. S. Maria de Vouzela (Viseu) (1700-1840)

Location: The province of Beira and the bishopric of Viseu. A rural parish in the hinterland of this city, which presently lies in the district of Viseu. Its parish church was constructed between the 12th and the 13th centuries.

Population stock (number of inhabitants):

1530: 292 From the Numeramento da População, cited in Colaço (1934).

1700: 560 From Costa (1706-12).

1758: No data in Memórias Paroquiais, see Capela (2010).

1801: 424 Silveira (2001).

1849: 624 Silveira (2001).

1864: 716 Censo (1868).

Source for births and deaths: Oliveira (2002). 


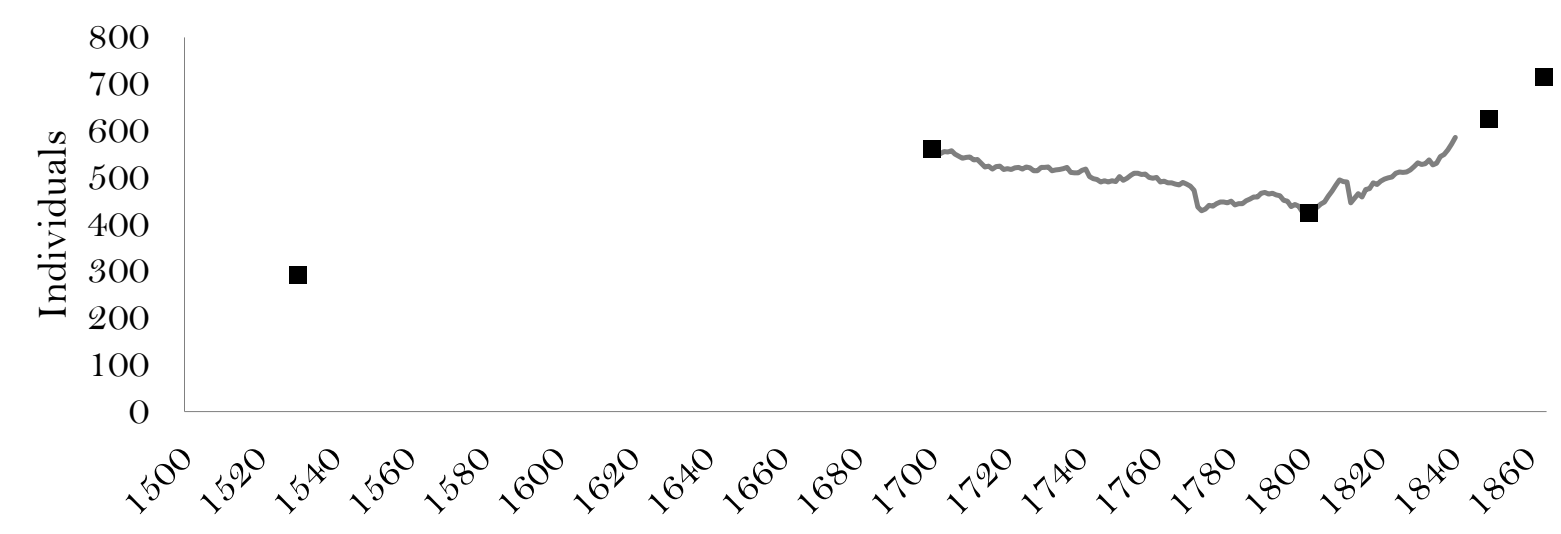

Figure C20. S. Maria deVouzela (Viseu)

$\underline{\text { C21. Nossa Senhora da Conceição de Nelas (Viseu) (1700-1812) }}$

Location: The province of Beira and the bishopric of Viseu. A rural parish in the hinterland of this city, which presently lies in the district of Viseu. It has not been possible to gather information about the historical background of this parish.

Population stock (number of inhabitants):

1530: 124 From the Numeramento da População, cited in Colaço (1934).

1700: 680 From Costa (1706-12).

1758: 980 From Memórias Paroquiais, cited in Capela (2010).

1801: 1,262 Silveira (2001).

1849: 1,857 Silveira (2001).

1864: 2,198 Censo (1868).

Source for births and deaths: Oliveira (2002). 


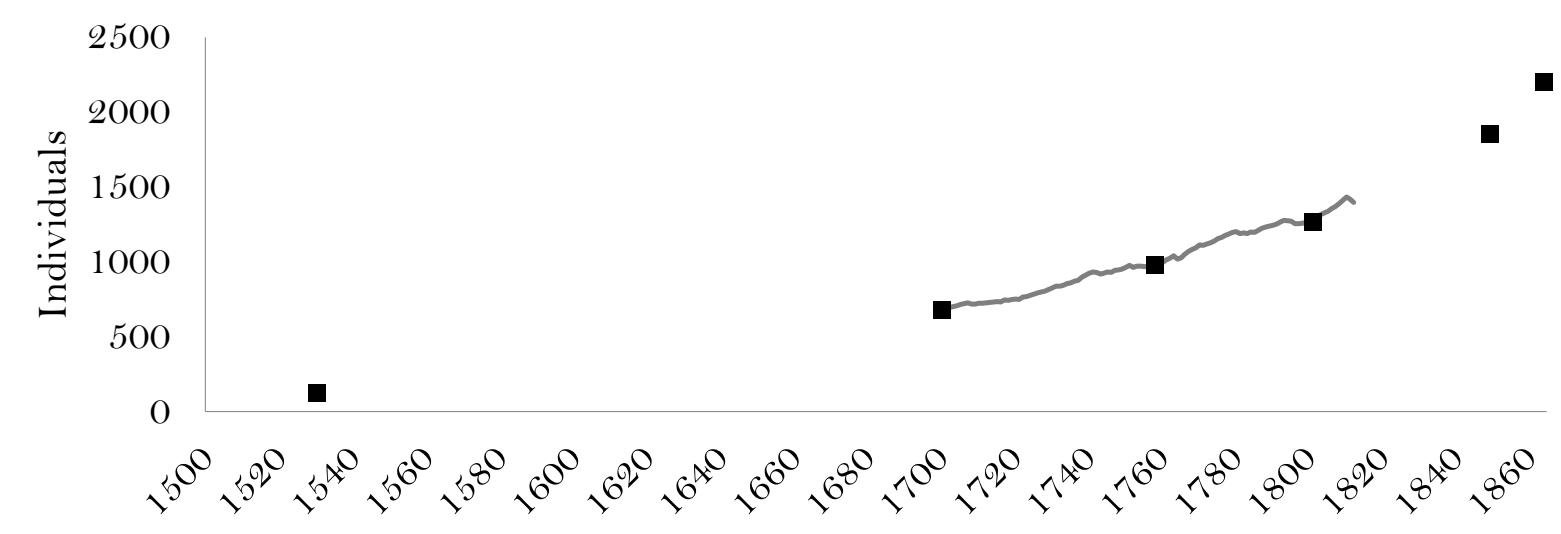

Figure C2 1. Nossa Senhora da Conceição de Nelas (Viseu)

C22. Canas de Sabugosa (Viseu) (1700-1840)

Location: The province of Beira and the bishopric of Viseu. A rural parish in the hinterland of this city, close to Tondela. Its earlier designation was Canas de Santa Maria. At present, it lies in the district of Viseu. The parish church was built and endowed by the wife of D. Afonso Henriques, the first king of Portugal (12th century).

Population stock (number of inhabitants):

1530: 80 From the Numeramento da População, cited in Colaço (1934).

1700: 920 From Costa (1706-12).

1758: 1,032 From Memórias Paroquiais, cited in Capela (2010).

1801: 961 Silveira (2001).

1849: 1,246 Silveira (2001).

1864: 794 Censo (1868).

Source for births and deaths: Oliveira (2002). 


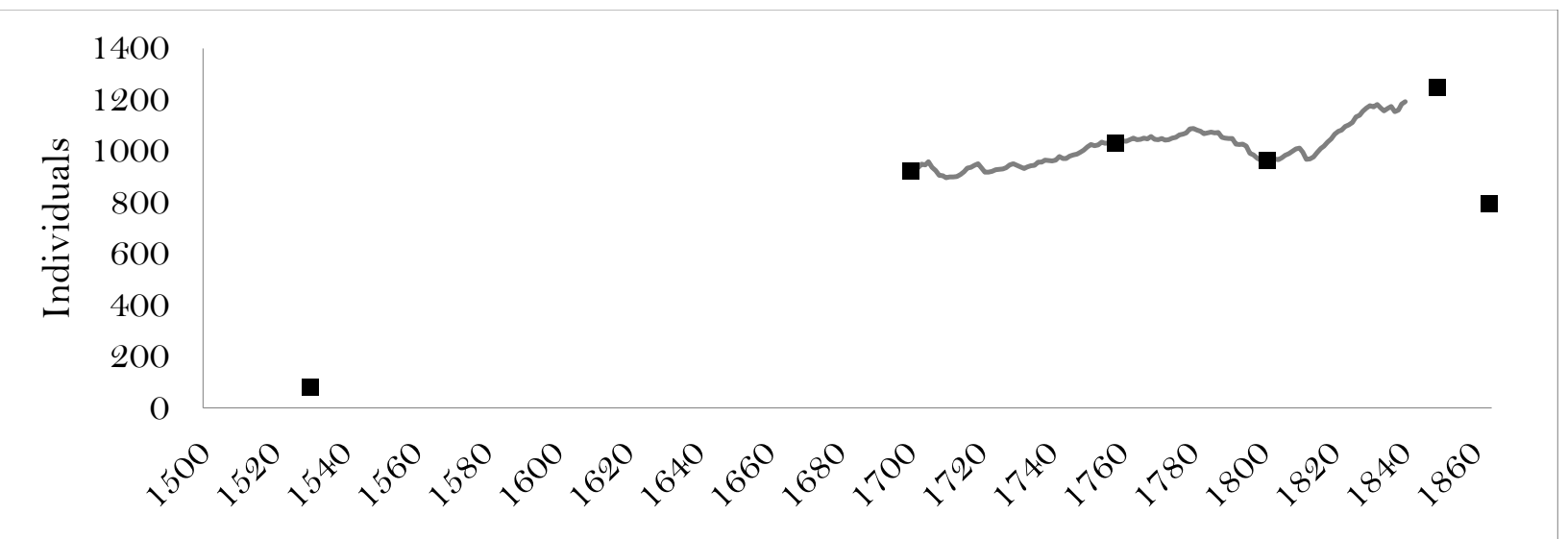

Figure C22. Canas de Sabugosa (Viseu)

C23. Santos Evos (Viseu) (1587-1700)

Location: The province of Beira and the bishopric of Viseu. A rural parish in the hinterland of this city, which lies in a remote corner of the district of Viseu. Little is known about this parish, except that it began to be settled in the 13 th century.

Population stock (number of inhabitants):

1530: 32 From the Numeramento da População, cited in Colaço (1934).

1700: 424 From Costa (1706-12).

1758: the available observation in the Memórias Paroquiais cited in Capela (2010) is clearly an outlier and has not been used.

1801: 670 Silveira (2001).

1849: 760 Silveira (2001).

1864: 1,102 Censo (1868).

Source for births and deaths: Oliveira (1990). 


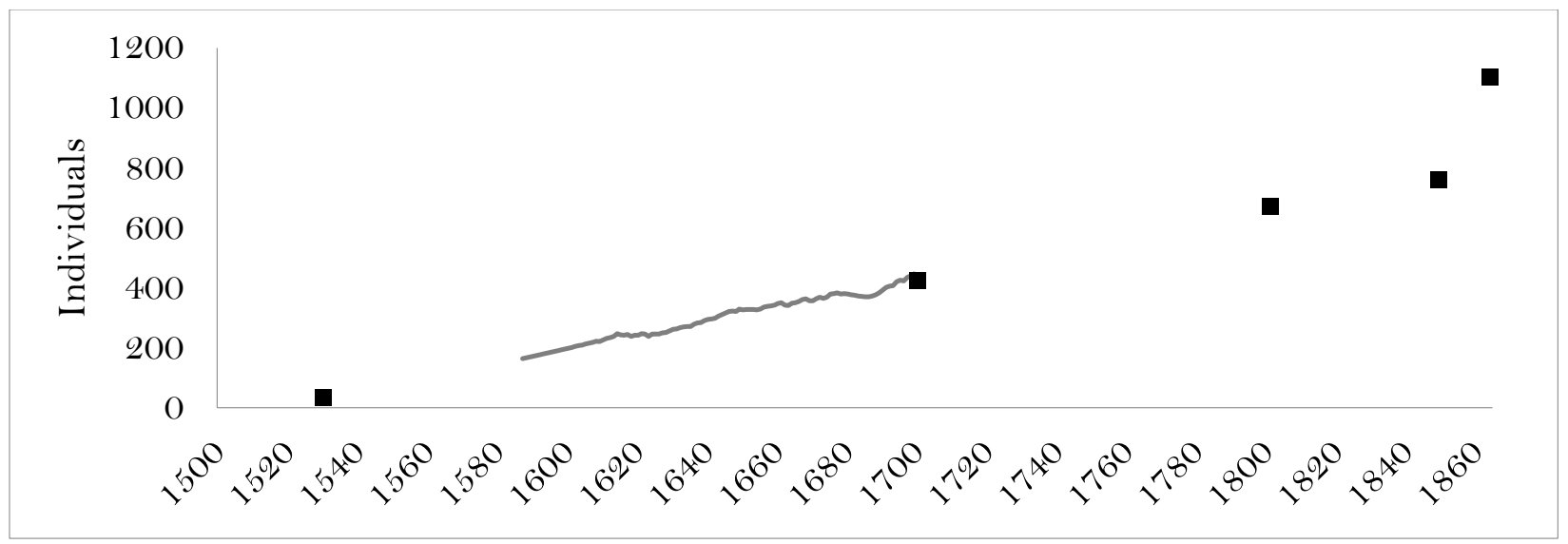

Figure C23. Santos Evos (Viseu)

$\underline{\text { C24. Nossa Senhora da Graça de Fragosela (Viseu) (1587-1700) }}$

Location: The province of Beira and the bishopric of Viseu. A rural parish in the hinterland of this city, which presently lies in the district of Viseu. Little is known about its historical antecedents.

Population stock (number of inhabitants):

1530172 From the Numeramento da População, cited in Colaço (1934).

1700 704 From Costa (1706-12).

1758: 720 From Memórias Paroquiais, cited in Capela (2010).

1801: 781 Silveira (2001).

1849: 876 Silveira (2001).

1864: 1,153 Censo (1868).

Source for births and deaths: Oliveira (1990). 


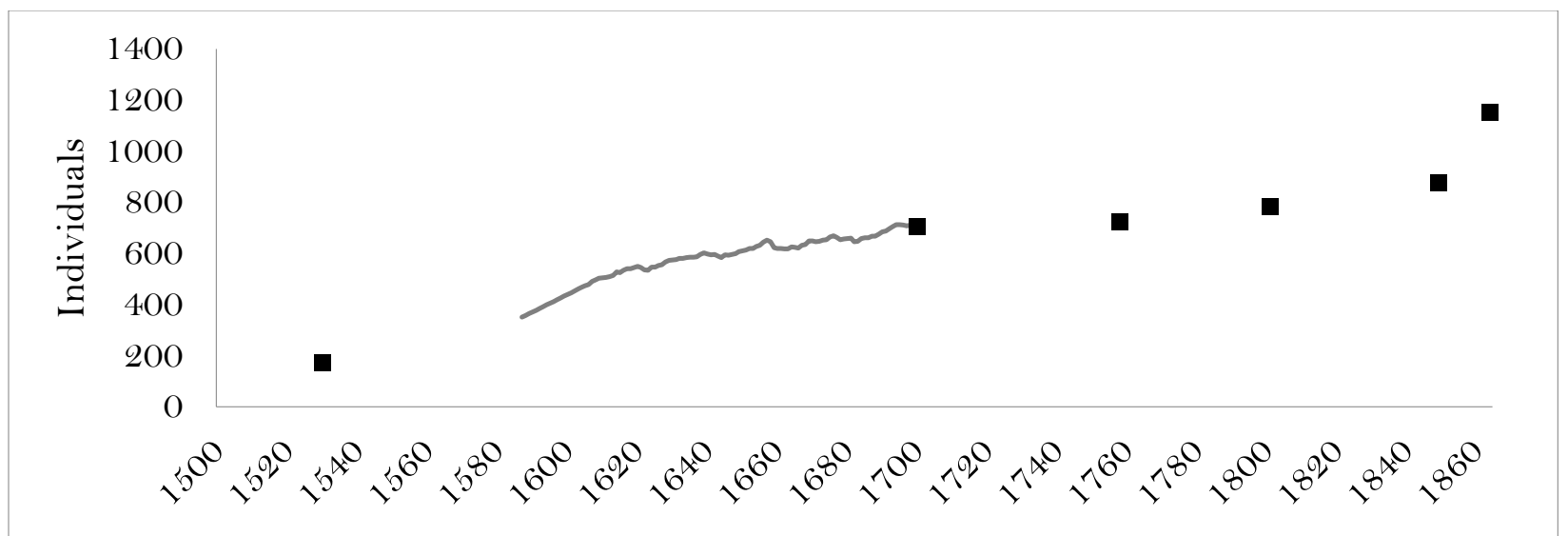

Figure C24. Nossa Senhora da Graça de Fragosela (Viseu)

C25. Vila Chã de Sá (Viseu) (1587-1701)

Location: The province of Beira and the bishopric of Viseu. A rural parish in the hinterland of this city, which presently lies in the district of Viseu. Little is known about its historical antecedents, except that there were transactions in land and windmills there after 1258 and that the parish was instituted before the 17 th century.

Population stock (number of inhabitants):

1530: 236 From the Numeramento da População, cited in Colaço (1934).

1700: No data, no reference to this parish in Costa (1706-12).

1758: 296 From Memórias Paroquiais, cited in Capela (2010).

1801: 447 Silveira (2001).

1849: 704 Silveira (2001).

1864: 721 Censo (1868).

Source for births and deaths: Oliveira (1990). 


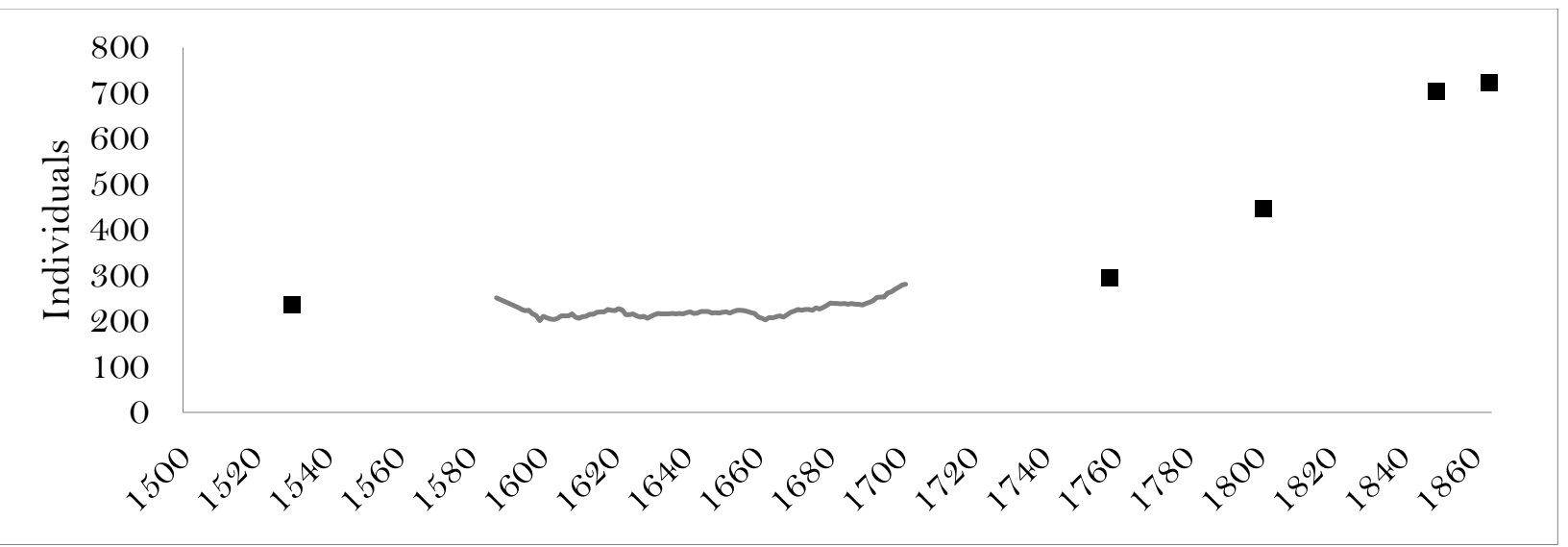

Figure C25. Vila Chã de Sá (Viseu)

C26. Nossa Senhora da Conceição de Mundão (Viseu) (1587-1700)

Location: The province of Beira and the bishopric of Viseu. A rural parish in the hinterland of this city, it presently lies in the district of Viseu. Mundão is mentioned in medieval documents since the mid-13th century but its parish was instituted only in 1510 .

Population stock (number of inhabitants):

1530: 116 From the Numeramento da População, cited in Colaço (1934).

1700: 320 From Costa (1706-12).

1758: 204 From Memórias Paroquiais, cited in Capela (2010).

1801: 447 Silveira (2001).

1849: 519 Silveira (2001).

1864: 641 Censo (1868).

Source for births and deaths: Oliveira (1990). 


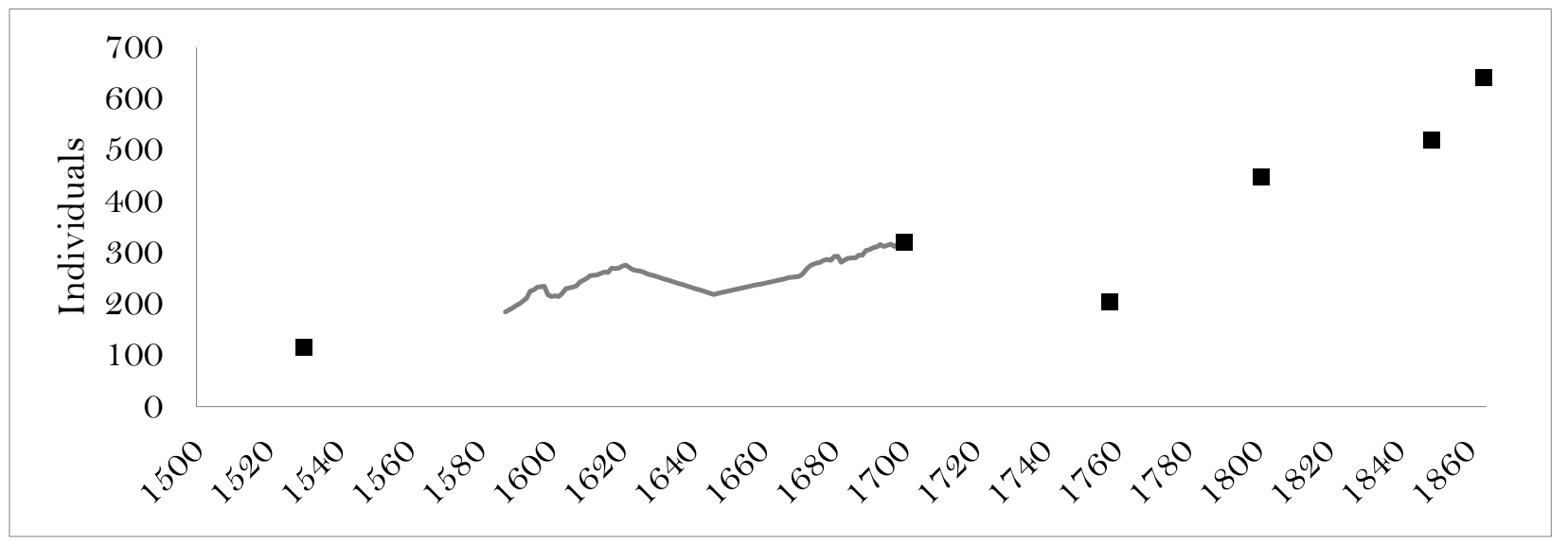

Figure C26. Nossa Senhora da Conceição de Mundão (Viseu)

\section{Entre-Douro-e-Minho}

D1. Alvito S. Pedro (1570-1864)

Location: The province of Entre Douro e Minho and the archbishopric of Braga. A rural parish comprising two parts - Alvito and Ginzo - close to the city of Barcelos. It belongs at present to the district of Braga. No infomation exists regarding the origins of this parish.

Population stock (number of inhabitants):

1530: 196 From Miranda (1993), citing the Numeramento da População.

1700: 320 From Costa (1706-12).

1758: 300 From Memórias Paroquiais, cited by Miranda (1993).

1801: 230 Silveira (2001).

1849: 289 Silveira (2001).

1864: 349 Censo (1868).

Source for births and deaths: Miranda (1993). 


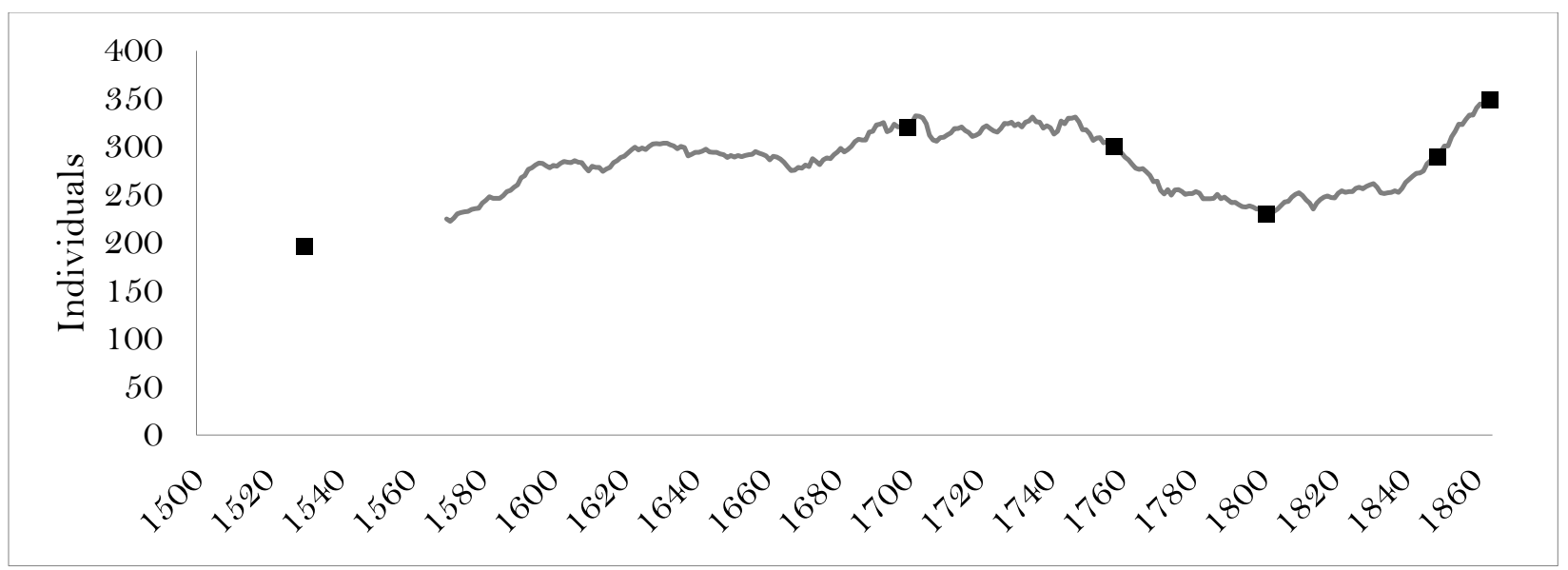

Figure D1. Alvito S. Pedro

D2. Santiago de Esporões (1700-1864)

Location: The province of Entre-Douro-e-Minho and the archbishopric of Braga. A rural parish close to the city of Braga and belonging at present to the district of Braga. Originally a pre-roman fortress town, the parish was first established in the 12th century, some of it with stone from the mosque of Cordoba, and renewed in the early 16th.

Population stock (number of inhabitants):

1530: No data in the Numeramento da População, in Freire (1903-1916), vol. III.

1700: 260 From Costa (1706-12).

1758: 525 Memórias Paroquiais, cited in Capela (2003).

1801: 501 Silveira (2001).

1849: 350 Silveira (2001).

1864: 558 Censo (1868).

Source for births and deaths: Data kindly supplied by Maria Hermínia Barbosa. 


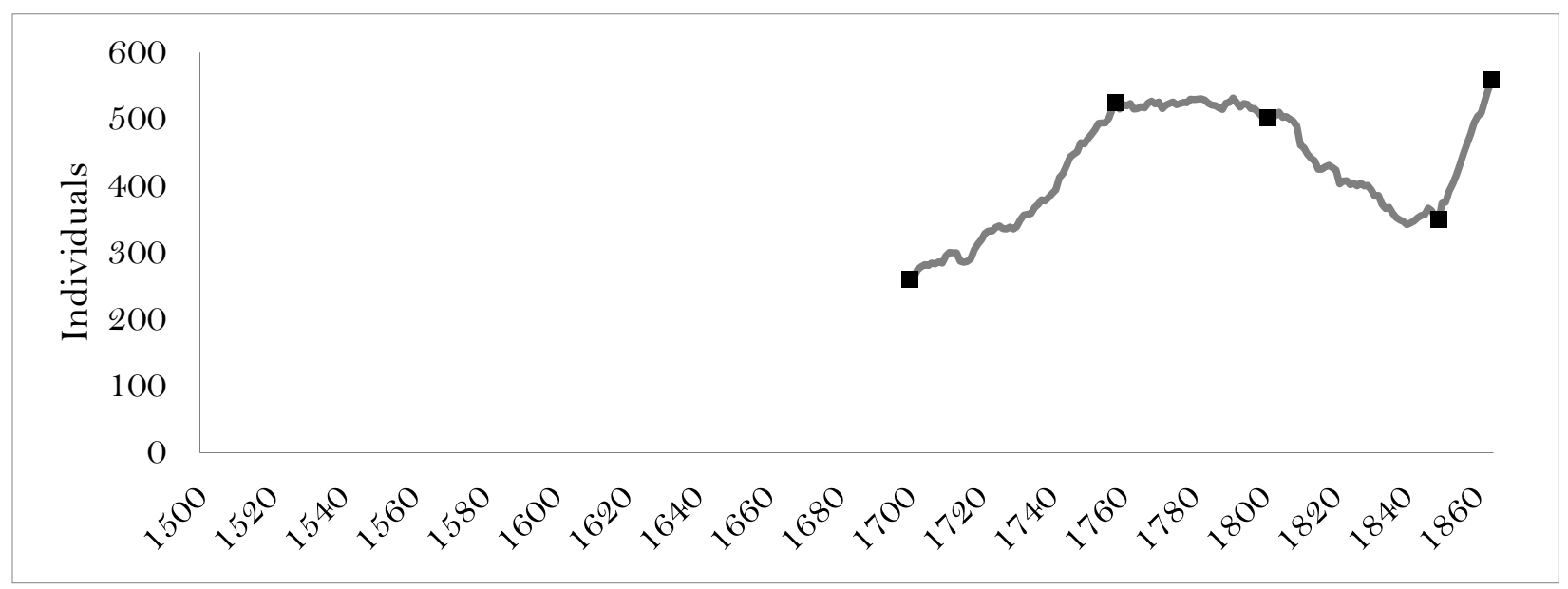

Figure D2.Santiago de Esporões

D3. S. Eulália de Fermentões (Guimarães) (1580-1820)

Location: The province of Entre-Douro-e-Minho and the archbishopric of Braga. A rural parish close to the city of Guimarães, it now belongs to the district of Braga. Originally a pre-roman fortress town, the parish existed already in 1061.

Population stock (number of inhabitants):

1530: 204 From the Numeramento da População, cited in Freire (1903-1916), vol. III.

1700: 360 From Costa (1706-12).

1758: 453 Memórias Paroquiais, cited in Capela (2003).

1801: 651 Silveira (2001).

1849: 785 Silveira (2001).

1864: 813 Censo (1868).

Source for births and deaths: Amorim (1987). 


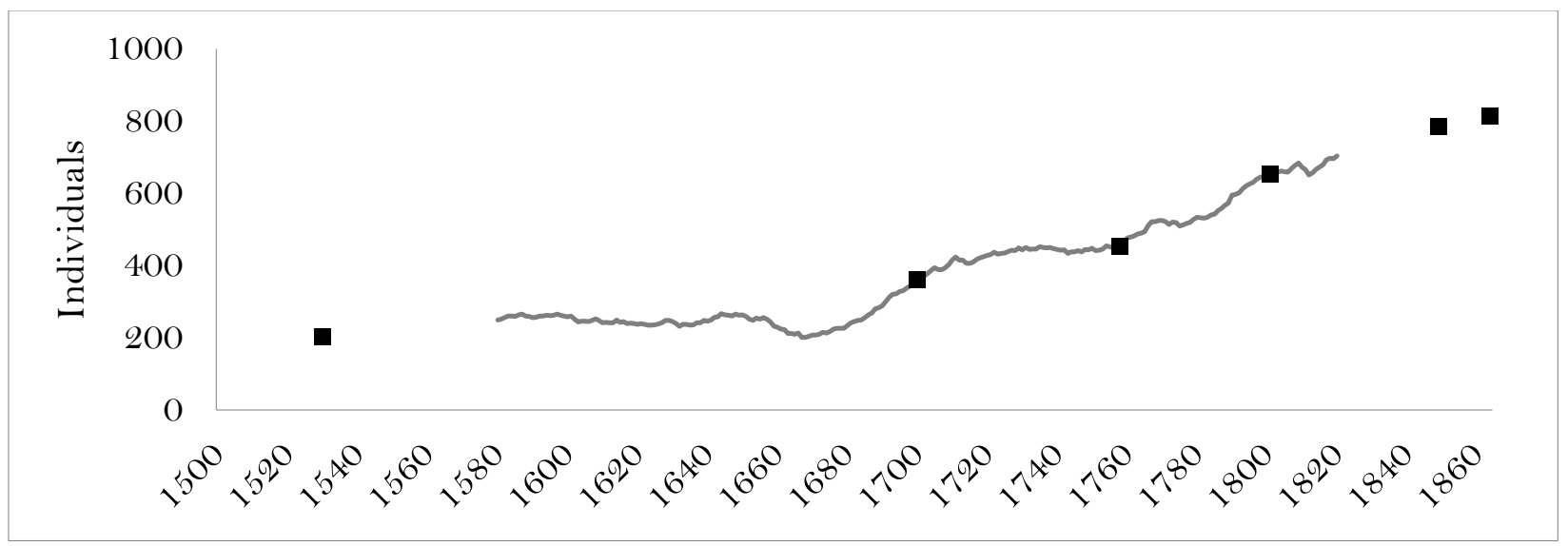

Figure D3. S. Eulália de Fermentões (Guimarães)

D4. Costa (Guimarães) (1700-1820)

Location: The province of Entre-Douro-e-Minho and the archbishopric of Braga. A rural parish close to the city of Guimarães, it now belongs to the district of Braga. Originally a pre-roman fortress town, the parish existed already in 1061. The foundation of the parish dates back to 1145 and was laid by the first queen of Portugal.

Population stock (number of inhabitants):

1530: No data in the Numeramento da População, cited in Freire (19031916), vol. III.

1700: 80 From Costa (1706-12).

1758: 208 Memórias Paroquiais, cited in Capela (2003).

1801: 353 Silveira (2001).

1849: 439 Silveira (2001).

1864: 456 Censo (1868).

Source for births and deaths: Amorim (1987). 


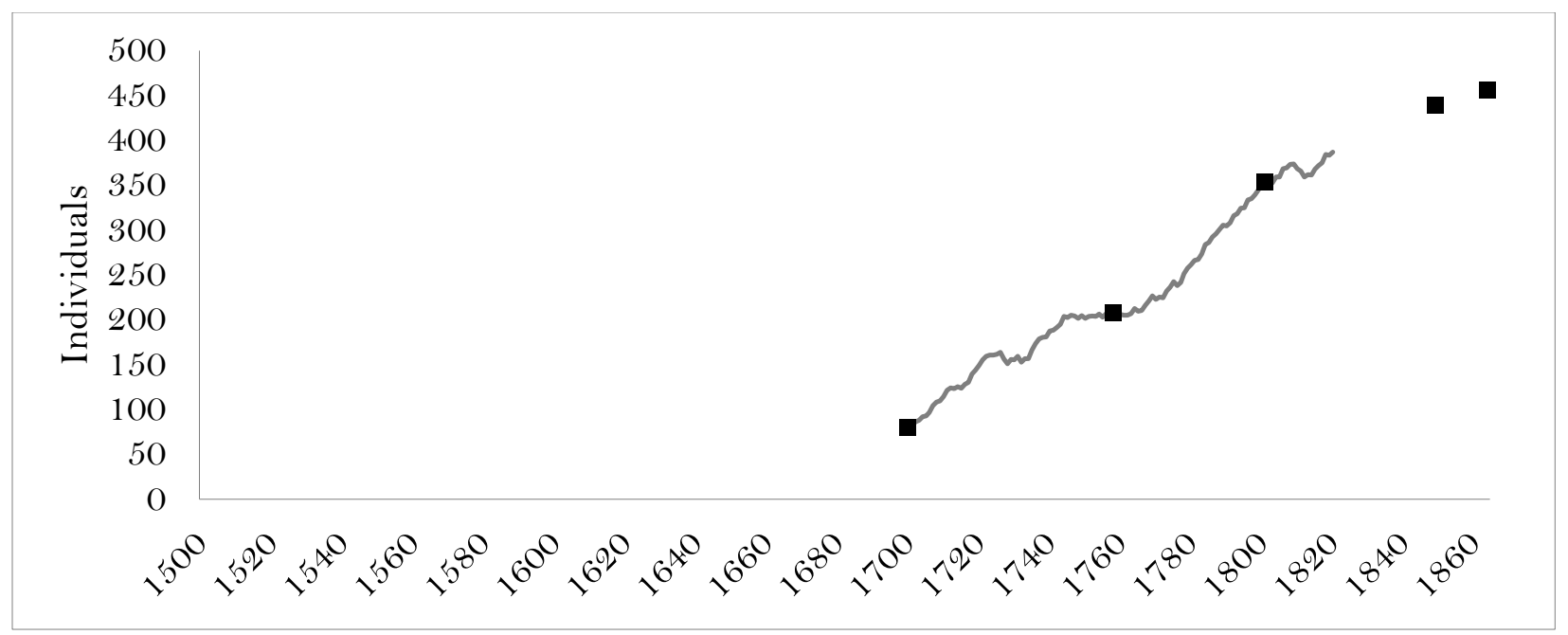

Figure D4. Costa (Guimarães)

D5. S. Romão de Mesão Frio (Guimarães) (1580-1820)

Location: The province of Entre-Douro-e-Minho and the archbishopric of Braga. A rural parish close to the city of Guimarães, it now belongs to the district of Braga. The origins of this parish are not known.

Population stock (number of inhabitants):

1530: 120 From the Numeramento da População, cited in Freire (1903-1916), vol. III.

1700: 300 From Costa (1706-12).

1758: 184 Memórias Paroquiais, cited in Capela (2003).

1801: 329 Silveira (2001).

1849: 386 Silveira (2001).

1864: 428 Censo (1868).

Source for births and deaths: Amorim (1987). 


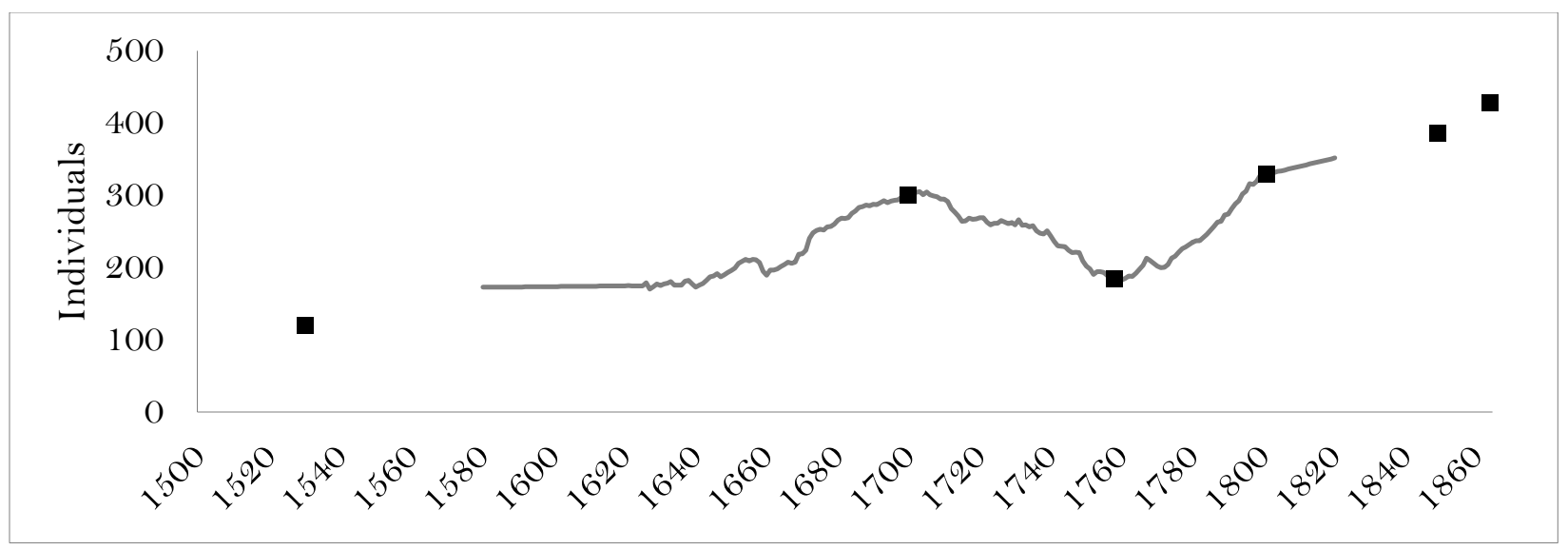

Figure D5. S. Romão de Mesão Frio (Guimarães)

D6. S.Estevão de Urgeses (Guimarães) (1580-1820)

Location: The province of Entre-Douro-e-Minho and the archbishopric of Braga. A rural parish close to the city of Guimarães, it now belongs to the district of Braga. The earliest references to this parish in documents date back to 1220 .

Population stock (number of inhabitants):

1530: 128 From the Numeramento da População, cited in , cited in Freire (1903-1916), vol. III.

1700: 320 From Costa (1706-12).

1758: 456 Memórias Paroquiais, cited in Capela (2003).

1801: 436 Silveira (2001).

1849: 617 Silveira (2001).

1864: 648 Censo (1868).

Source for births and deaths: Amorim (1987). 


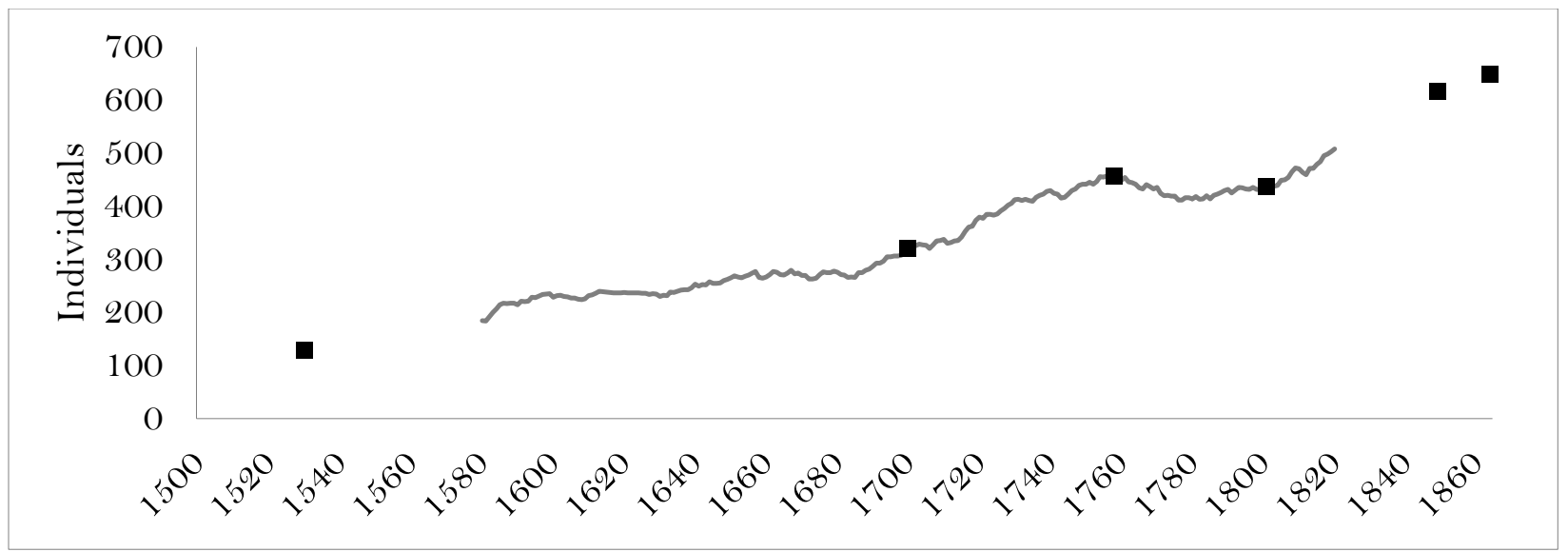

Figure D6. S. Estevão de Urgeses (Guimarães)

D7. Oliveira do Castelo (Guimarães) (1726-1820)

Location: The province of Entre-Douro-e-Minho and the archbishopric of Braga. One of the four urban parishes of the city of Guimarães, it now belongs to the district of Braga. The earliest mention of this parish dates back to 1139 .

Population stock (number of inhabitants):

1530: No data in the Numeramento da População, cited in Freire (1903-1916), vol. III.

1700: Mentioned in Costa (1706-12) but not quantified.

1726: 3,060 Craesbeeck' Memoirs (1726) cited in Amorim (1987).

1758: 2,756 From Memórias Paroquiais, cited in Capela (2003).

1801: 2,450 Silveira (2001).

1849: 2,938 Silveira (2001).

1864: 3,400 Censo (1868).

Source for births and deaths: Amorim (1987). 


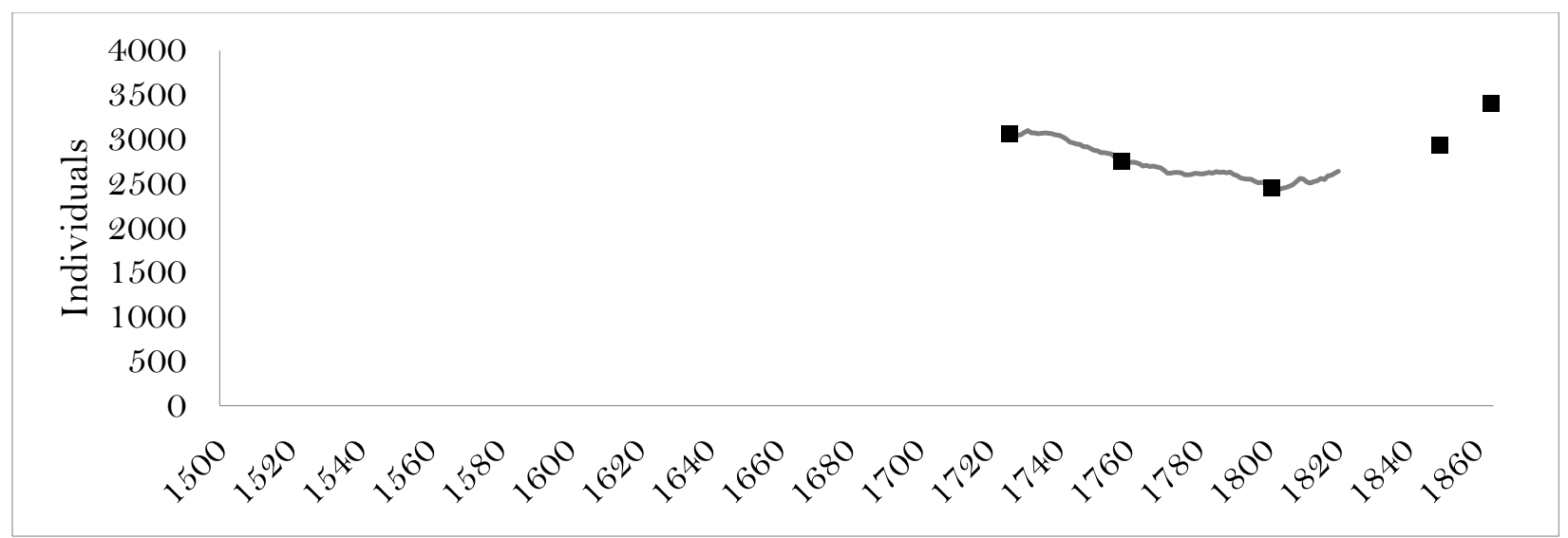

Figure D7. Oliveira do Castelo (Guimarães)

D8. S. Sebastião (Guimarães) (1726-1864)

Location: The province of Entre-Douro-e-Minho and the archbishopric of Braga. One of the four urban parishes of the city of Guimarães, it now belongs to the district of Braga. It appears to have been founded sometime in the $13^{\text {th }}$ century.

Population stock (number of inhabitants):

1530: No data in the Numeramento da População, cited in Freire (19031916), vol. III.

1700: No data; mentioned in Costa (1706-12) but not quantified.

1728: 1,726 Craesbeeck' Memoirs (1726) cited in Amorim (1987).

1758: 1,688 Memórias Paroquiais, cited in Capel (2003).

1801: 2,120 Silveira (2001).

1849: 2,047 Silveira (2001).

1864: 2,418 Censo (1868).

Source for births and deaths: Amorim (1987). 


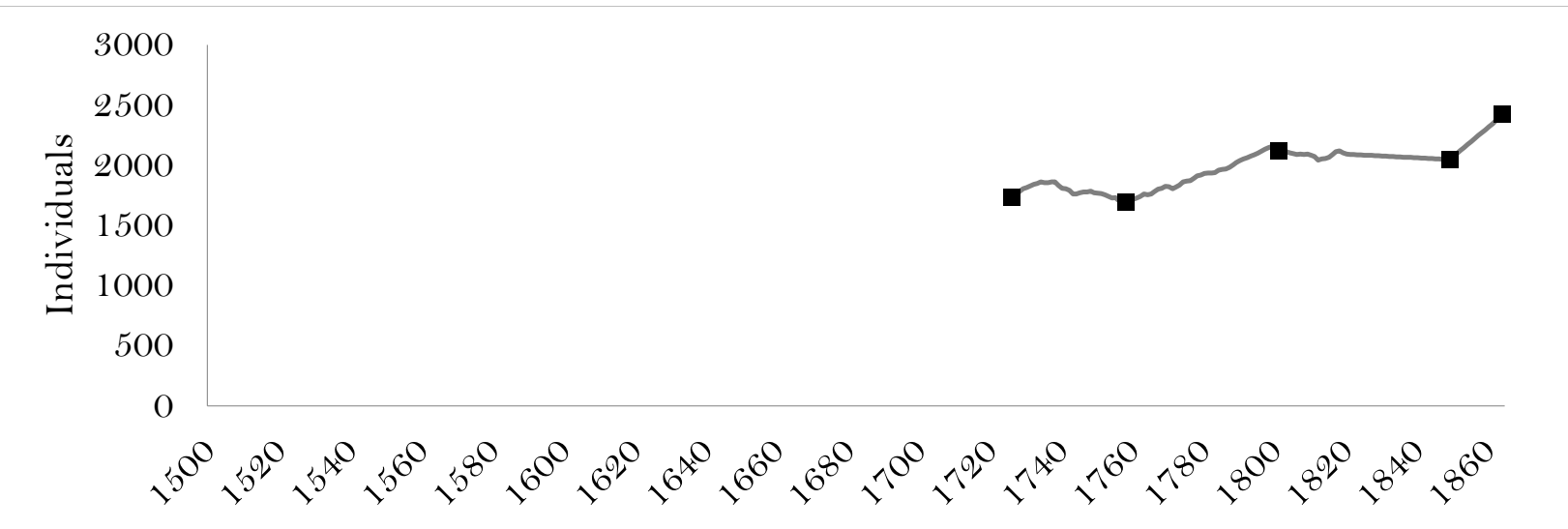

Figure D8. S. Sebastião (Guimarães)

D9. S. Paio (Guimarães) (1580-1820)

Location: The province of Entre-Douro-e-Minho and the archbishopric of Braga. One of the four urban parishes of the city of Guimarães, it now belongs to the district of Braga. The origins of this parish go back to the $13^{\text {th }}$ century.

Population stock (number of inhabitants):

1530: 288 From the Numeramento da População, cited in Freire (1903-1916), vol. III.

1700: No data; mentioned in Costa (1706-12) but not quantified.

1726: 1,560 Craesbeeck' Memoirs (1726) cited in Amorim (1987).

1758: 2,348 Memórias Paroquiais, cited in Amorim (1987).

1801: 1,959 Silveira (2001).

1849: 1,662 Silveira (2001).

1864: 1,935 Censo (1868).

Source for births and deaths: Amorim (1987). 


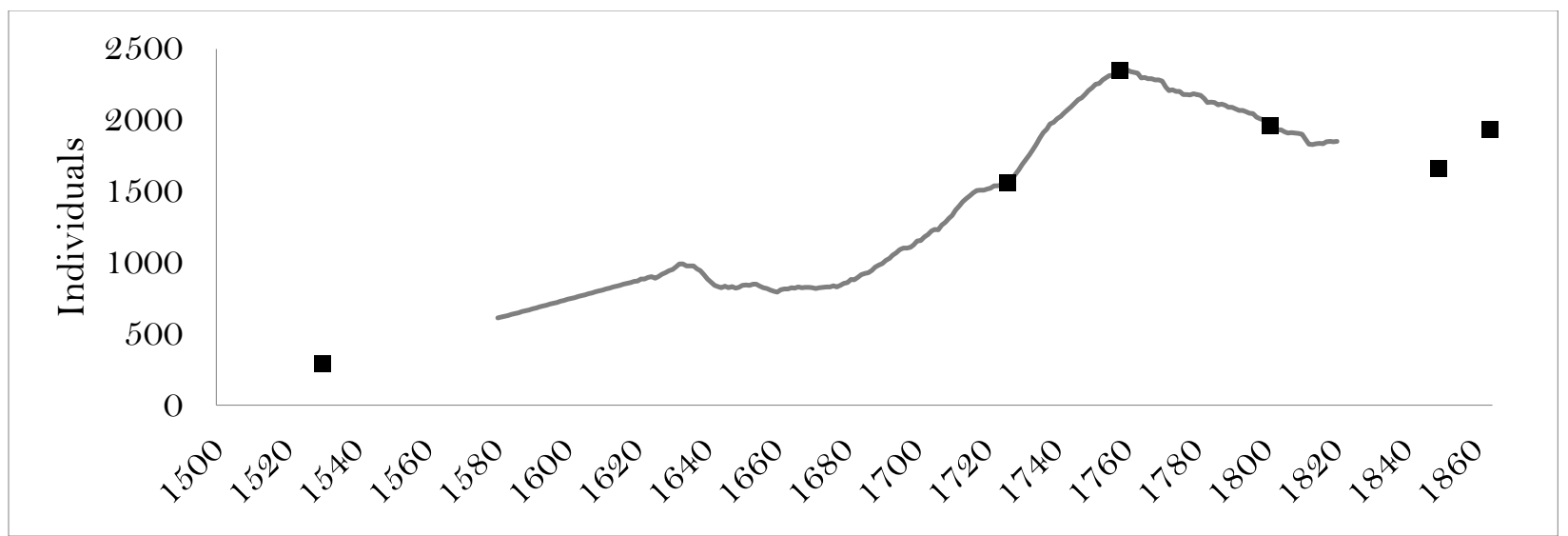

Figure D9. S. Paio (Guimarães)

D10. Castelo (Guimarães) (1758-1820)

Location: The province of Entre-Douro-e-Minho and the archbishopric of Braga. One of the four urban parishes of the city of Guimarães, it now belongs to the district of Braga. Already in existence around the early 12th century, it is believed that the first king of Portugal was baptised in this parish.

Population stock (number of inhabitants):

1530: 236 From the Numeramento da População, cited in Freire (1903-1916), vol. III.

1700: No data; mentioned in Costa (1706-12) but not quantified.

1758: 68 Memórias Paroquiais, cited in Amorim (1987).

1801: 48 Silveira (2001).

1849: 68 Silveira (2001).

1864: 139 Censo (1868).

Source for births and deaths: Amorim (1987). 


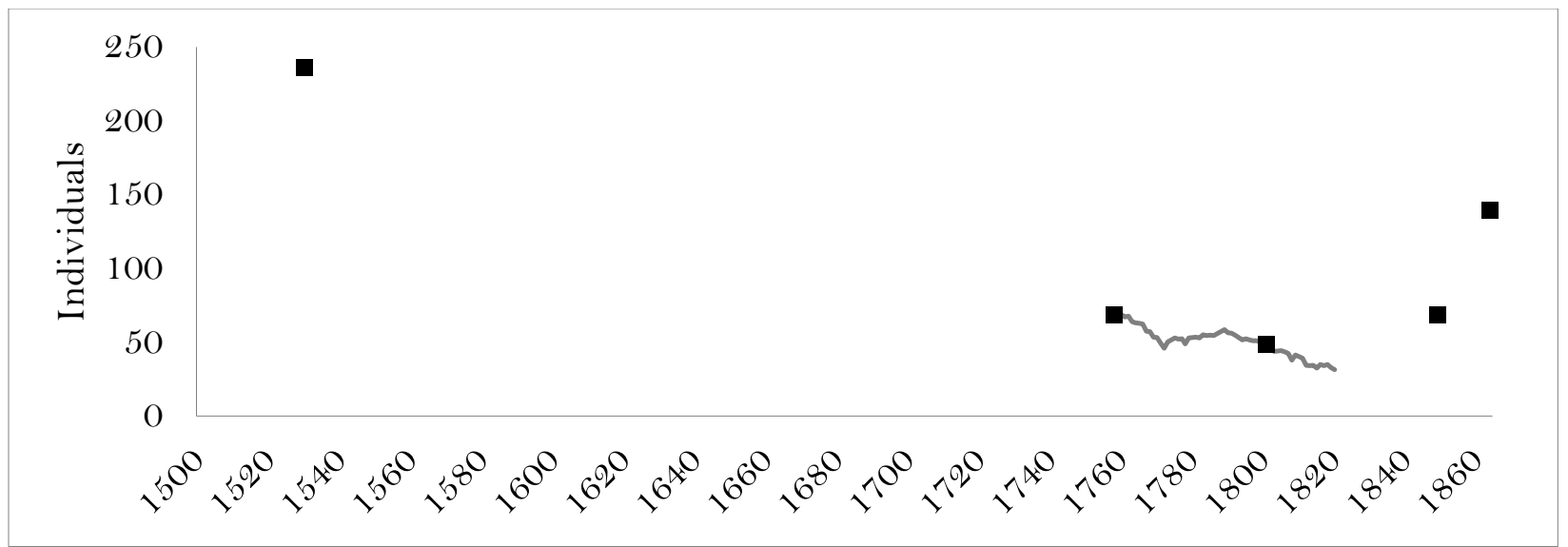

Figure D10. Castelo (Guimarães)

D11. S. Tiago de Creixomil (Guimarães) (1580-1820)

Location: The province of Entre-Douro-e-Minho and the archbishopric of Braga. A suburban parish of the city of Guimarães, it now belongs to the district of Braga. In 959 Creixomil was already a well-organized settlement, whose owner gave it his name. The general belief is that the parish existed before the foundation of Portugal (1140).

Population stock (number of inhabitants):

1530: 160 From the Numeramento da População, , cited in Freire (19031916), vol. III.

1700: 840 From Costa (1706-12).

1758: 1,300 From Memórias Paroquiais, cited in Capela (2003).

1801: 1,024 Silveira (2001).

1849: 1,059 Silveira (2001).

1864: 1,579 Censo (1964).

Source for births and deaths: Amorim (1987). 


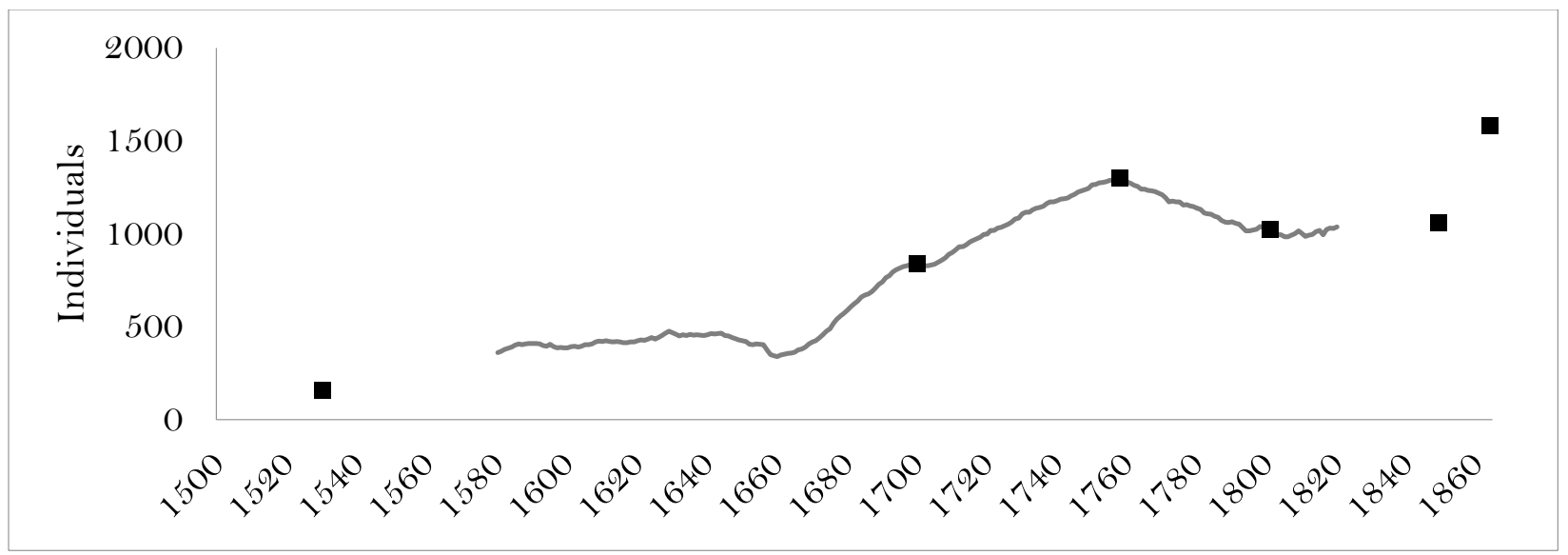

Figure D11. S. Tiago de Creixomil (Guimarães)

D12. S. Pedro de Azurem (Guimarães) (1580-1820)

Location: The province of Entre-Douro-e-Minho and the archbishopric of Braga. A suburban parish of the city of Guimarães, it now belongs to the district of Braga. The first mention of the parish dates back to the middle of the 10th century.

Population stock (number of inhabitants):

1530: 100 From the Numeramento da População, cited in Freire (1903-1916), vol. III.

1700: 400 From Costa (1706-12).

1758: 840 From Memórias Paroquiais, cited in Capela (2003).

1801: 890 Silveira (2001).

1849: 620 Silveira (2001).

1864: 1,029 Censo (1864).

Source for births and deaths: Amorim (1987). 


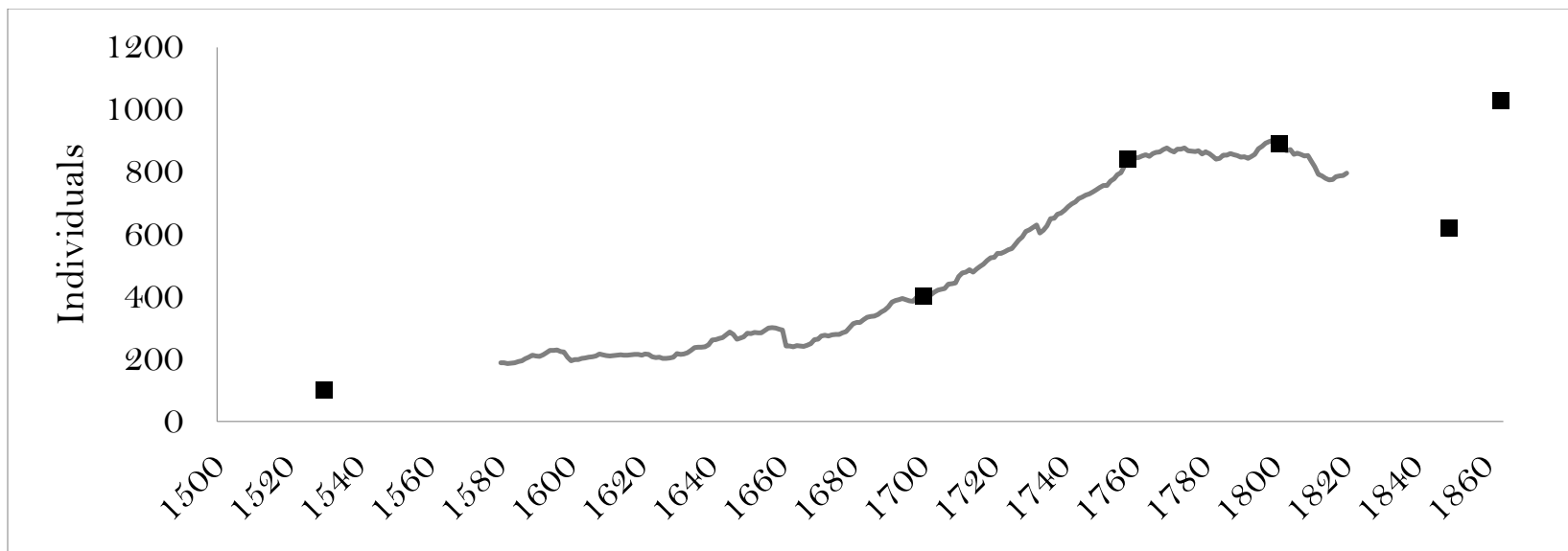

Figure D12. S. Pedro de Azurem (Guimarães)

\section{D13. S. Marinha de Gontinhães (1624-1864)}

Location: The province of Entre-Douro-e-Minho and the archbishopric of Braga. A fishing parish close to the town of Caminha, it now belongs to the district of Viana de Castelo. The first mention of Gontinhães dates back to 1258, when the parish belonged to the bishopric of Tui, in Spain.

Population stock (number of inhabitants):

1530: 304 From the Numeramento da População, cited in Freire (1903-1916), vol. III.

1700: 800 From Costa (1706-12), cited in Rego (2012).

1758: 876 From Memórias Paroquiais, cited in Rego (2012).

1801: 842 Silveira (2001).

1849: 1,066 Silveira (2001).

1864: 1,215 Censo (1868).

Source for births and deaths: Rego (2012). 


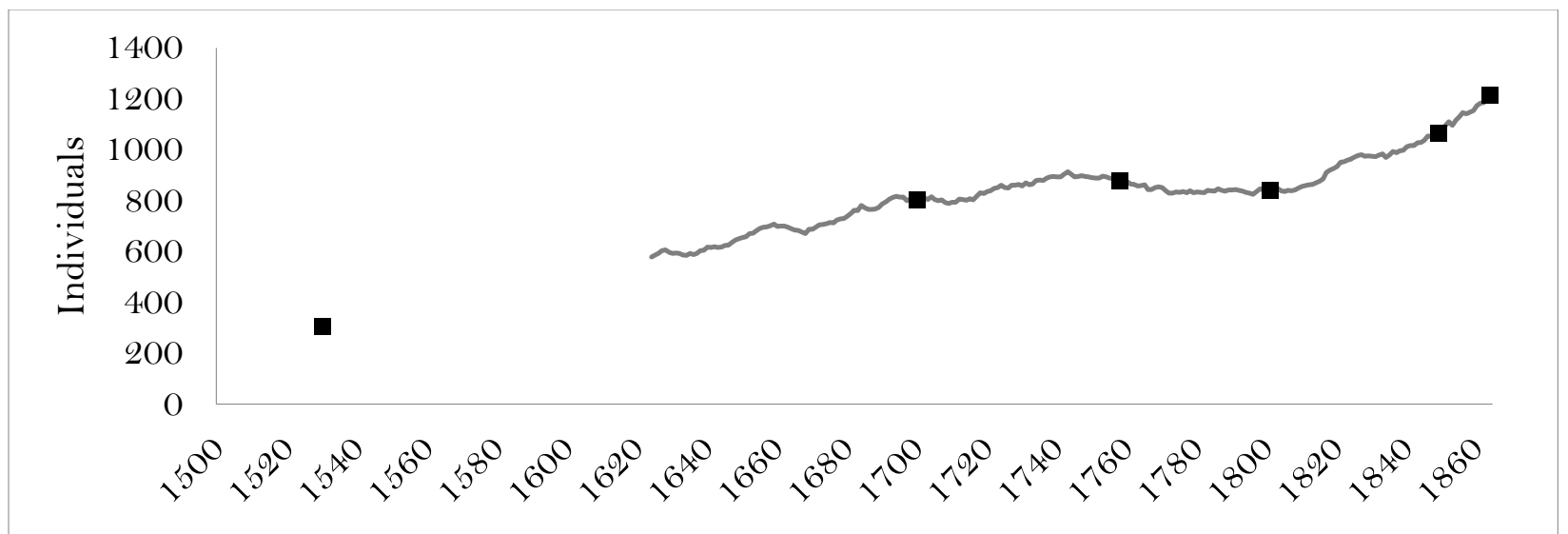

Figure D13. S. Marinha de Gontinhães

D14. Santiago de Romarigães (1640-1864)

Location: The province of Entre-Douro-e-Minho and the archbishopric of Braga. A rural parish close to the town of Paredes de Coura, it belongs at present to the district of Viana do Castelo. Its origins as a parish lie somewhere between the 12th and the 13th centuries. As a community, however, they belong to the period of the Reconquest.

Population stock (number of inhabitants):

1530: 132 From the Numeramento da População, cited in Santos (1999).

1700: 460 From Costa (1706-12).

1758: 436 Memórias Paroquiais, cited in Santos (1999).

1801: 448 Silveira (2001).

1849: 486 Silveira (2001).

1864: 544 Censo (1868).

Source for births and deaths: Data kindly supplied by Carlota Santos. 


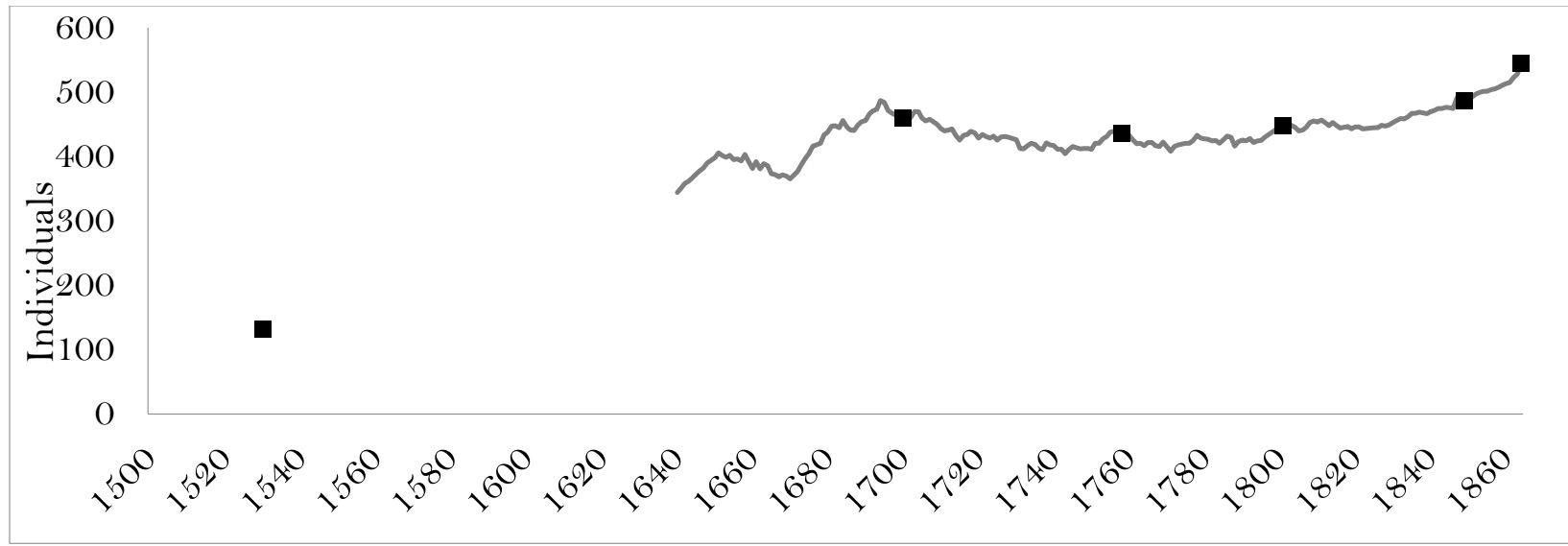

Figure D14. Santiago de Romarigães

D15. S. João Baptista de Canelas (1589-1808)

Location: The province of Entre-Douro-e-Minho and the archbishopric of Braga. A rural parish close to the port of Vila Nova de Gaia, it now belongs to the district of Braga. The first mention of the parish dates back to the middle of the 10th century.

Population stock (number of inhabitants):

1530: 168 From the Numeramento da População, cited in Costa (1994).

1700: 840 From Costa (1706-12), cited in Costa (1994).

1758: 720 From Memórias Paroquiais, cited in Costa (1994).

1801: 970 Silveira (2001).

1849: 1,031 Silveira (2001).

1864: 1,285 Censo (1868).

Source for births and deaths: Costa (1994). 


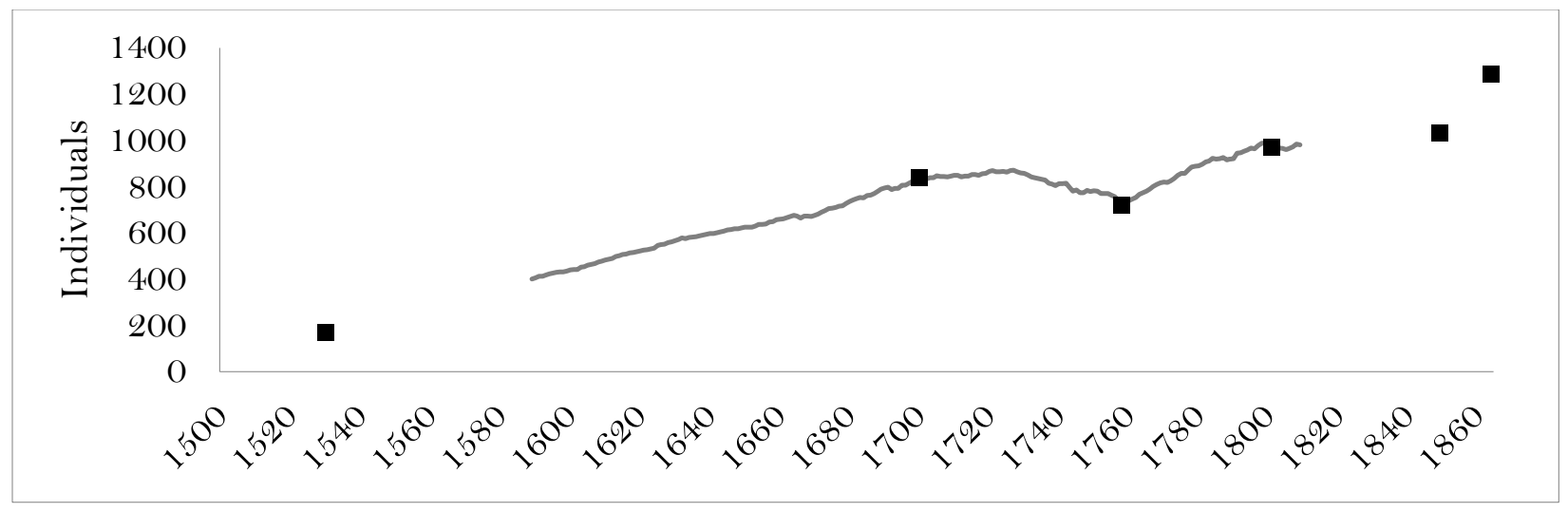

Figure D15. S. João Baptista de Canelas (1589-1808)

\section{D16. S.João Baptista. de Vila do Conde (1595-1640)}

.Location: The province of Entre-Douro-e-Minho and the bishopric of Porto. An important port and fishing centre close to Porto, the second largest city of Portugal, it now belongs to the district of Porto. The first documentary mention of Vila do Conde dates back to the early 13 th century.

Population stock (number of inhabitants):

1530: 3,620 From the Numeramento da População, cited in Polónia (1999).

1620: 2,964 From Polónia (1999).

1700: 3,600 From Costa (1706-12).

1758: 4,312 From Memórias Paroquiais, cited in Polónia (1999).

1801: 3,604 Silveira (2001).

1849: 3,620 Silveira (2001).

1864: 4,356 Censo (1868).

Source for births and deaths: Data kindly supplied by Cristina Giesteira, of the Arquivo Municipal de Vila do Conde, under the CEDOPORMAR group. 


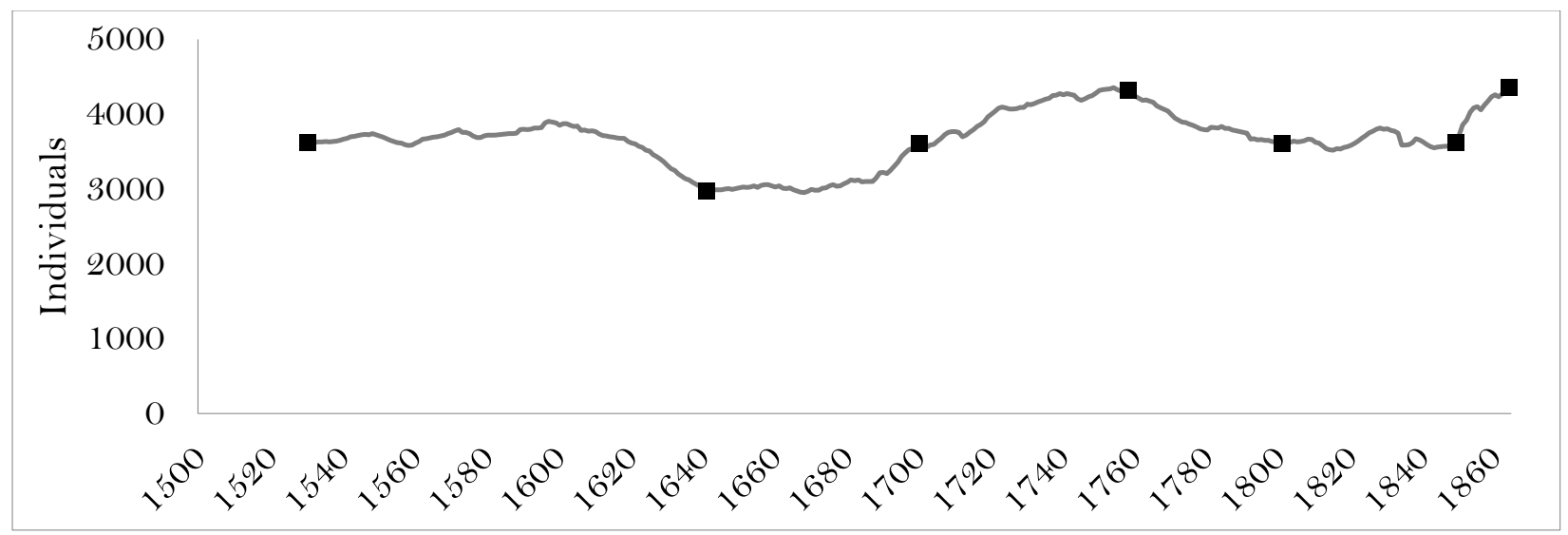

Figure D16. S.João Baptista de Vila do Conde

\section{D17. S. João das Caldas (1588-1864)}

Location: The province of Entre-Douro-e-Minho and the archbishopric of Braga. A rural parish rich in mineral waters and close to the city of Guimarães, it now belongs to the district of Braga. The first mention of this parish dates back to the time of the Visigoths, who had a church there in the 6th century. It was solidly established by the early 13th century.

Population stock (number of inhabitants):

1530: 96 From the Numeramento da População, cited in Freire (1903-1916), vol. III.

1700: 280 From Costa (1706-12).

1758: 404 From Memórias Paroquiais, cited in Capela (2003).

1801: 448 Silveira (2001).

1849: 584 Silveira (2001).

1864: 712 Censo (1868).

Source for births and deaths: Ferreira (2001). 


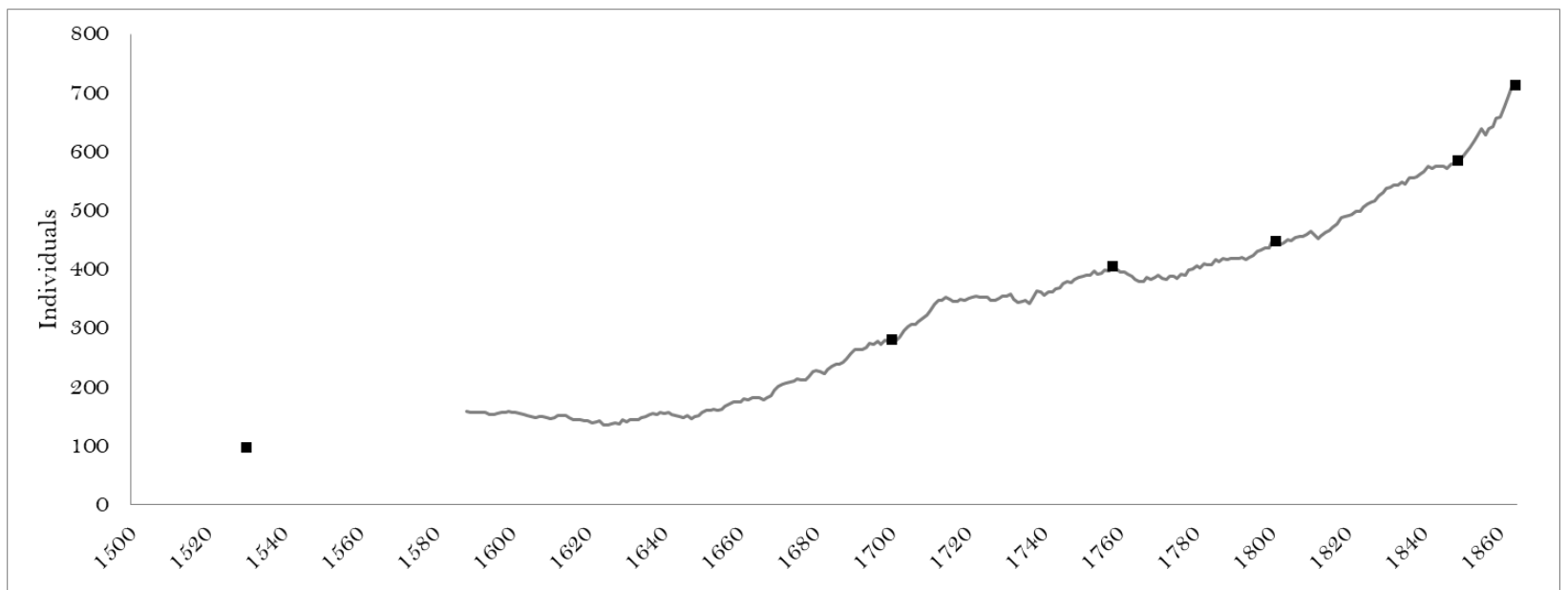

Figure D17. S. João das Caldas

D18. S. Martinho de Ávidos (1623-1864)

Location: The province of Entre-Douro-e-Minho and the archbishopric of Braga. A rural parish in the county of Famalicão, it now belongs to the district of Braga. The earliest written reference to this parish dates back to the middle of the 13 th century.

Population stock (number of inhabitants):

1530: 240 From the Numeramento da População, cited in Leite (1999).

1700: 360 From Costa (1706-12).

1758: 312 From Memórias Paroquiais, cited in Leite (1999).

1801: 386 Silveira (2001).

1849: 296 Silveira (2001).

1864: 449 Censo (1868).

Source for births and deaths: Leite (1999). 


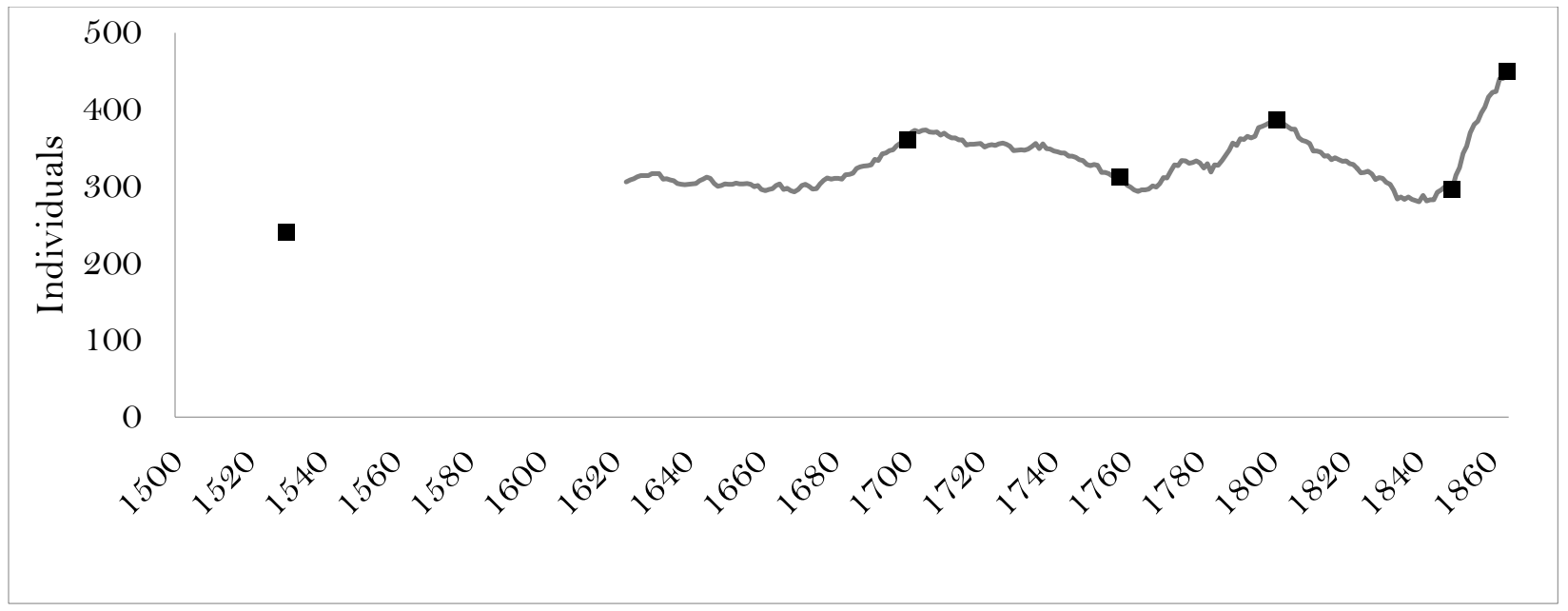

Figure D18. S. Martinho de Ávidos (1623-1864)

D19. S. Pedro de Esmeriz (1597-1864)

Location: The province of Entre-Douro-e-Minho and the archbishopric of Braga. A rural parish in the county of Famalicão, it now belongs to the district of Braga. The earliest written reference to this parish dates back to the middle of the 13 th century.

Population stock (number of inhabitants):

1530: 104 From the Numeramento da População. cited in Freire (19031916), vol. III.

1700: 280 From Costa (1706-12).

1758: 260 From Memórias Paroquiais, cited in Soares (1987).

1801: 229 Silveira (2001).

1849: 373 Silveira (2001).

1864: 546 Censo (1868).

Source for births and deaths: Soares (1987). 


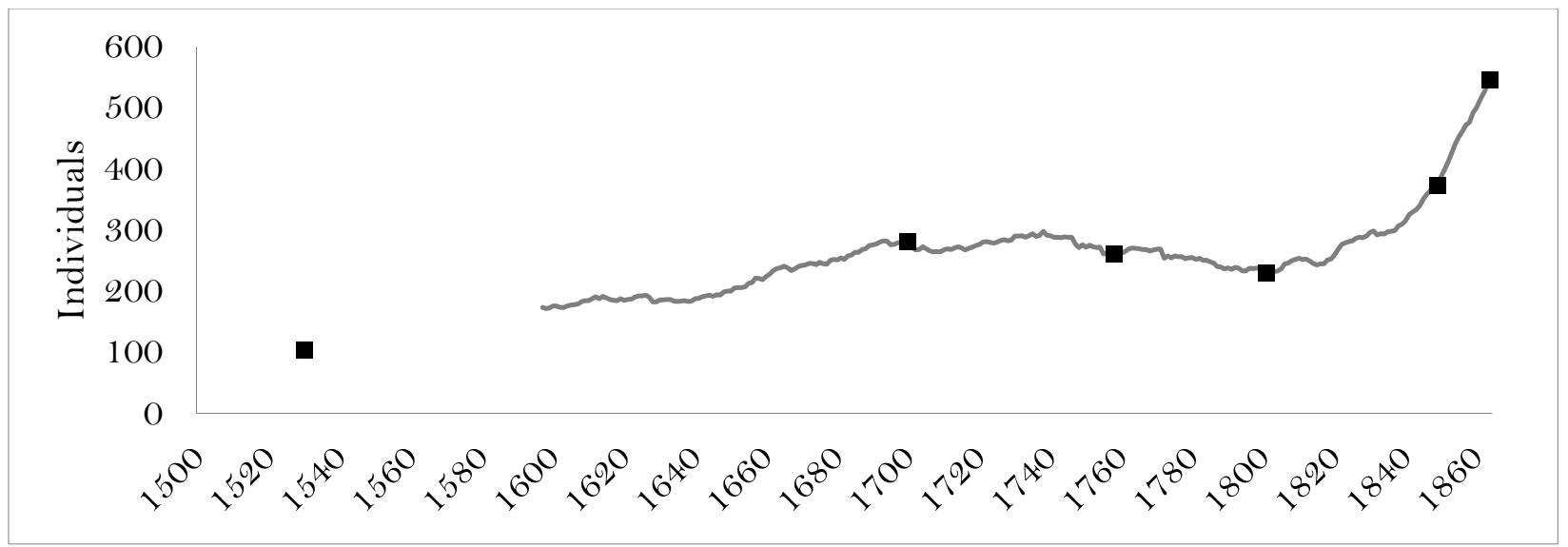

Figure D19. S. Pedro de Esmeriz (1597-1864)

D20. S. Tiago de Bougado (1650-1849)

Location: The province of Entre-Douro-e-Minho and the archbishopric of Braga. A rural parish in a suburban área close to Porto. It now belongs to the district of Porto. Originally a Roman township, the parish had gained a clear identity by the middle of the 13 th century.

Population stock (number of inhabitants):

1530: 228 From the Numeramento da População, cited in Alves (1986).

1621: 521 From Alves (1868, p.56)

1700: 744 From Costa (1706-12).

1758: 1,016 From Memórias Paroquiais, cited in Alves (1986).

1801: 768 Silveira (2001).

1849: 1,138 Silveira (2001).

1864: 1,413 Censo (1868).

Source for births and deaths: Alves (1986). 


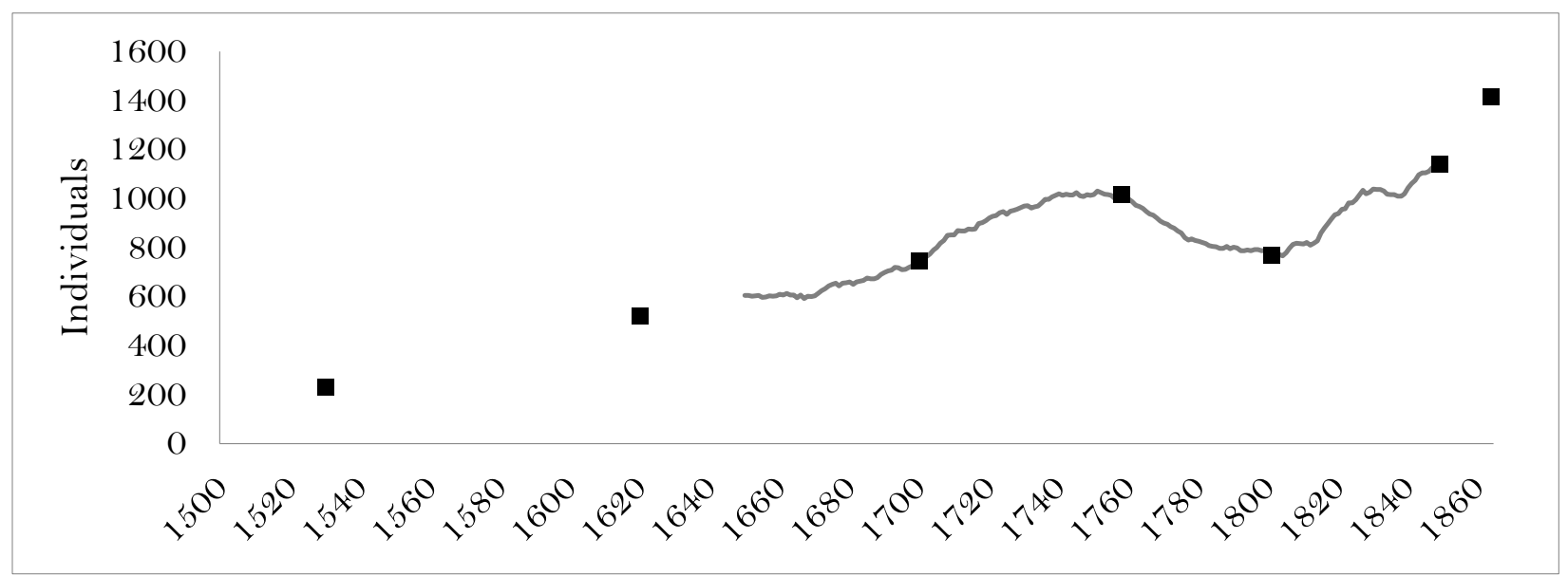

Figure D20. S. Tiago de Bougado

\section{D21. S. Tiago de Lordelo (1624-1851)}

Location: The province of Entre-Douro-e-Minho and the archbishopric of Braga. A rural parish in an area close to the town of Barcelos. It now belongs to the district of Braga. Although believed to have emerged in the visigothic era, firm evidence regarding this parish only exists from early in the 12 th century.

Population stock (number of inhabitants):

1530: 232 From the Numeramento da População, cited in Janeiro (1987).

1700: 384 From Costa (1706-12).

1758: 520 From Memórias Paroquiais, cited in Janeiro (1987).

1801: 779 Silveira (2001).

1849: 26 Silveira (2001).

1864: 961 Censo (1868).

Source for births and deaths: Janeiro (1997). 


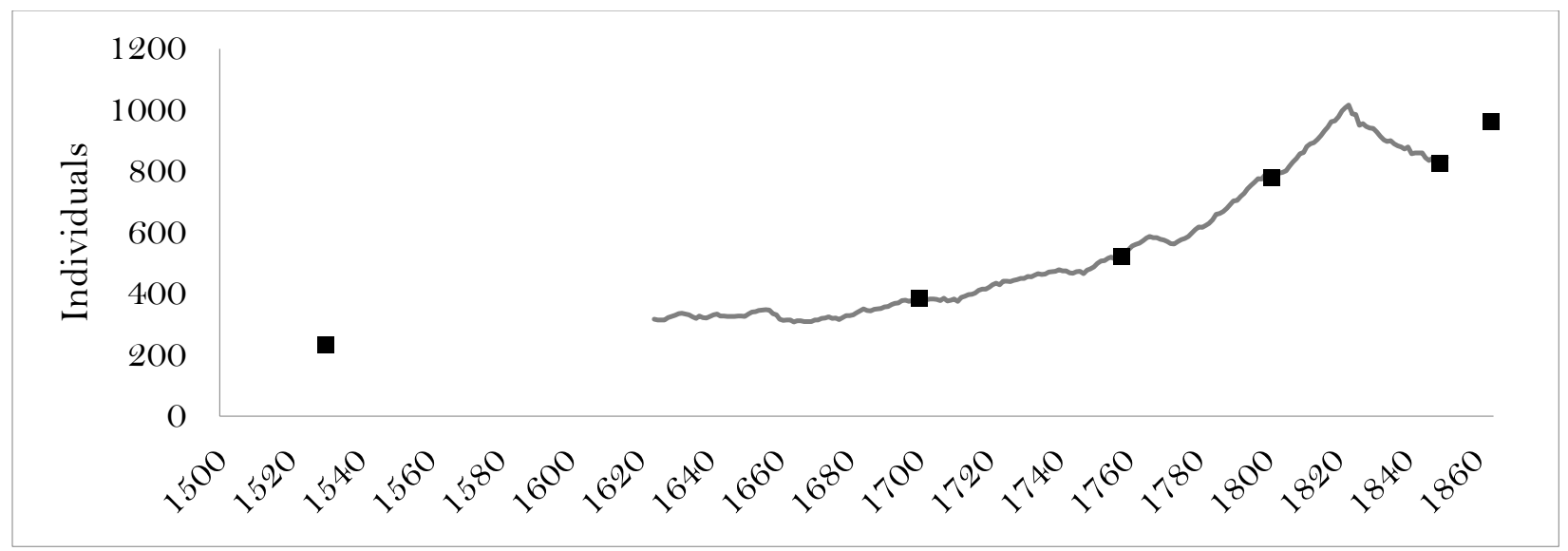

Figure D21. S. Tiago de Lordelo

D22. S. Tiago de Ronfe (1651-1864)

Location: The province of Entre-Douro-e-Minho and the archbishopric of Braga. A rural parish in an area close to the town of Guimarães. It now belongs to the district of Braga. Originally a Roman villa, it is mentioned for the the first time in the Christian era in a document of 1033.

\section{Population stock (number of inhabitants):}

1530: 164 From the Numeramento da População, cited in Freire (1903-1916), vol. III.

1700: 840 From Costa (1706-12).

1758: 776 From Memórias Paroquiais, cited in Capela (2003).

1801: 779 Silveira (2001).

1849: 826 Silveira (2001).

1864: 961 Censo (1868).

Source for births and deaths: Scott (1999) using data furnished by Norberta Amorim. 


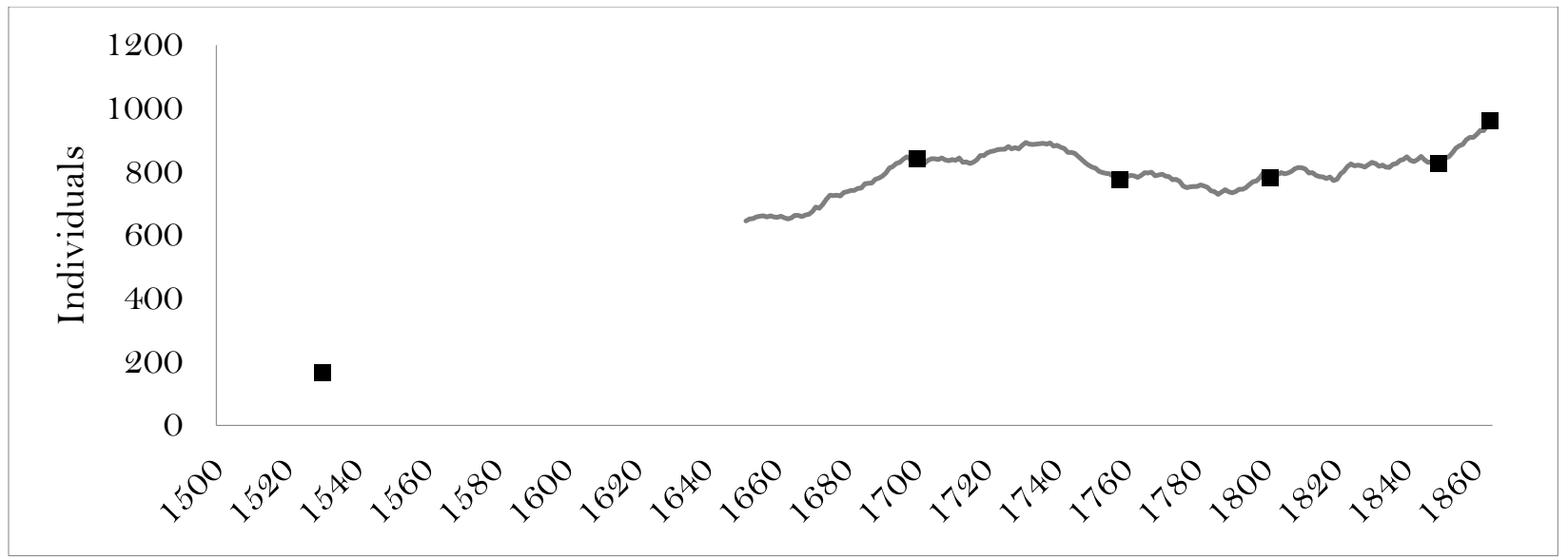

Figure D22. S. Tiago de Ronfe

\section{D23. S. Miguel de Oliveira do Douro (1700-1825)}

Location: The province of Entre-Douro-e-Minho and the bishopric of Lamego. A rural parish belonging to the municipality of Cinfães and not to be confused with the parish of the same name near the mouth of the river Douro. It now belongs to the district of Viseu. Originally a Roman villa, it received a municipal charter already in the mid-13th century.

Population stock (number of inhabitants):

1530: 256 From the Numeramento da População, cited in Freire (1903-1916), vol. III.

1700: Data unavailable in Costa (1706-12).

1758: 1,388 From Memórias Paroquiais, and cited in Capela (2010).

1801: 1,919 Silveira (2001).

1849: 1,783 Silveira (2001).

1864: 2,376 Censo (1868).

Source for births and deaths: Oliveira (2002). 


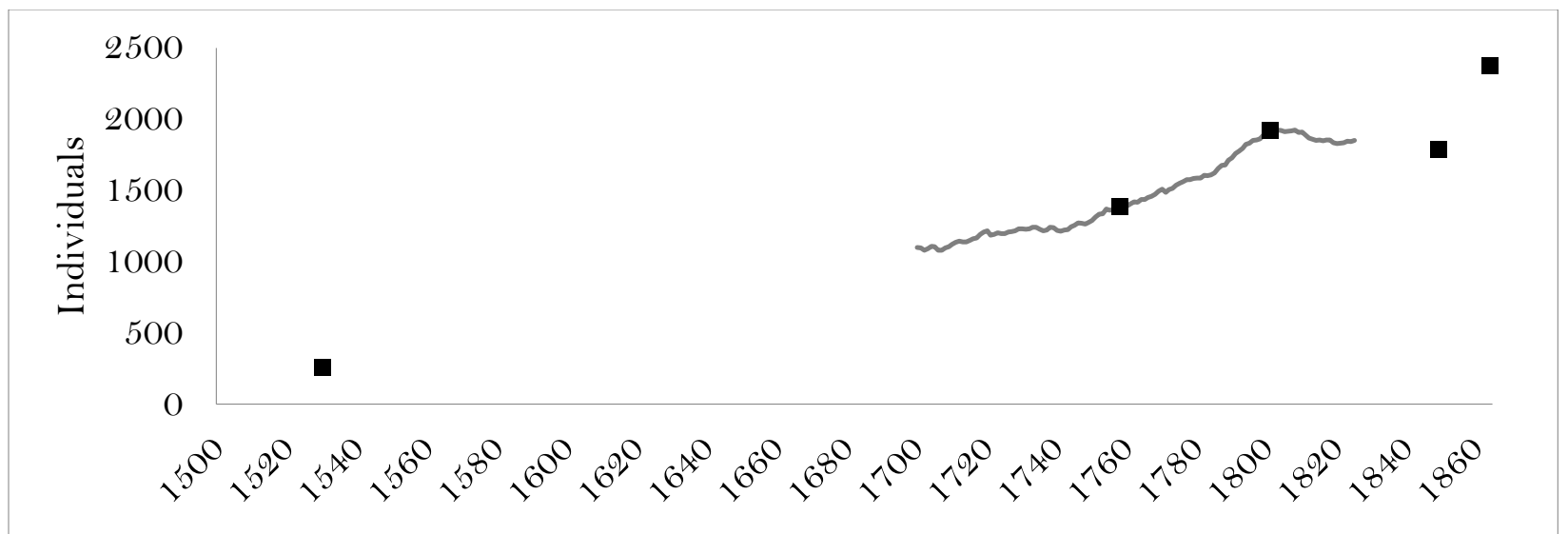

Figure D23. S. Miguel de Oliveira do Douro

D24. Nossa Senhora da Póvoa de Varzim (1700-1864)

Location: The province of Entre-Douro-e-Minho and the bishopric of Porto. A busy port for trade and fishing north of the mouth of the river Douro. It now belongs to the district of Porto. Already during the Roman occupation it was a significant urban centre, which increased its wealth during the 16th century on the basis of its vigorous naval industry. The earliest reference in writing to Povoa de Varzim dates back to the 10th century.

Population stock (number of inhabitants):

1530: 428 From the Numeramento da População, cited in Freire (1903-1916), vol. III.

1700: 400 From Costa (1706-12).

1758: 1,740 From Memórias Paroquiais, and cited in Capela (2009).

1801: 4,671 Silveira (2001).

1849: 8,959 Silveira (2001).

1864: 10,090 Censo (1868).

Source for births and deaths: Data kindly supplied by Cristina Giesteira (CEDOPORMAR). 


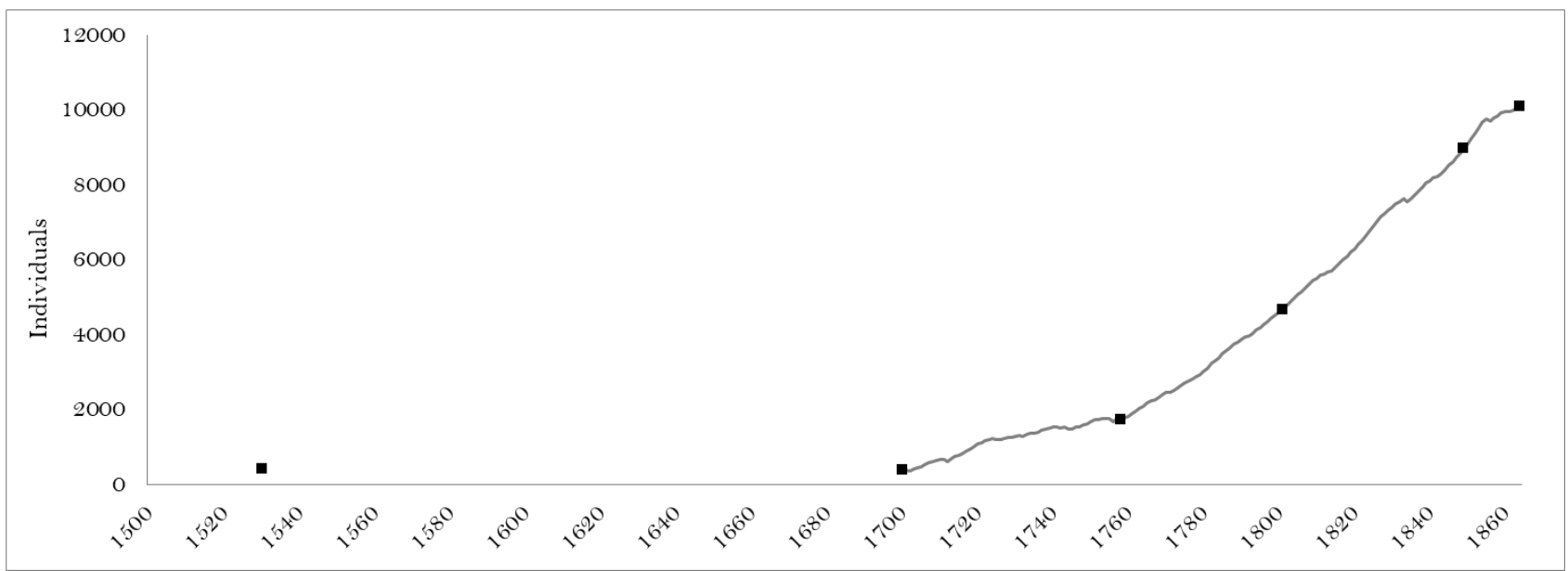

Figure D24. Nossa Senhora da Conceição da Póvoa de Varzim

\section{E. Estremadura}

\section{E1. S. Pedro de Barcarena (1620-1864)}

Location: The province of Estremadura and the archbishopric of Lisbon. A busy rural parish in the hinterland of Lisbon, its prosperity has derived from agriculture, fishing and gunpowder manufacturing, from the 14th century. It now belongs to the district of Lisboa. During the Roman occupation it was a significant urban centre. In the Christian era it increased its wealth further and in the 16th century did so on the basis of a vigorous naval industry.

Population stock (number of inhabitants):

1530: No data found in the Numeramento da População, cited in Freire (19031916), vol. VI.

1620: 976 From Oliveira (1620).

1700: 1,552 From Costa (1706-12).

1758: 1,504 From Arquivo Naciona da Torre do Tombo: Barcarena, Lisboa - Memórias paroquiais, vol. 6, n 31, p. 203 a 204.

1801: 1,691 Silveira (2001).

1849: 1,372 Silveira (2001). 
1864: 1,355 Censo (1868).

Source for births and deaths: Arquivo Distrital de Lisboa, Registos Paroquiais, Barcarena: Baptismos - B1 to B7; Óbitos - O1 to 4.

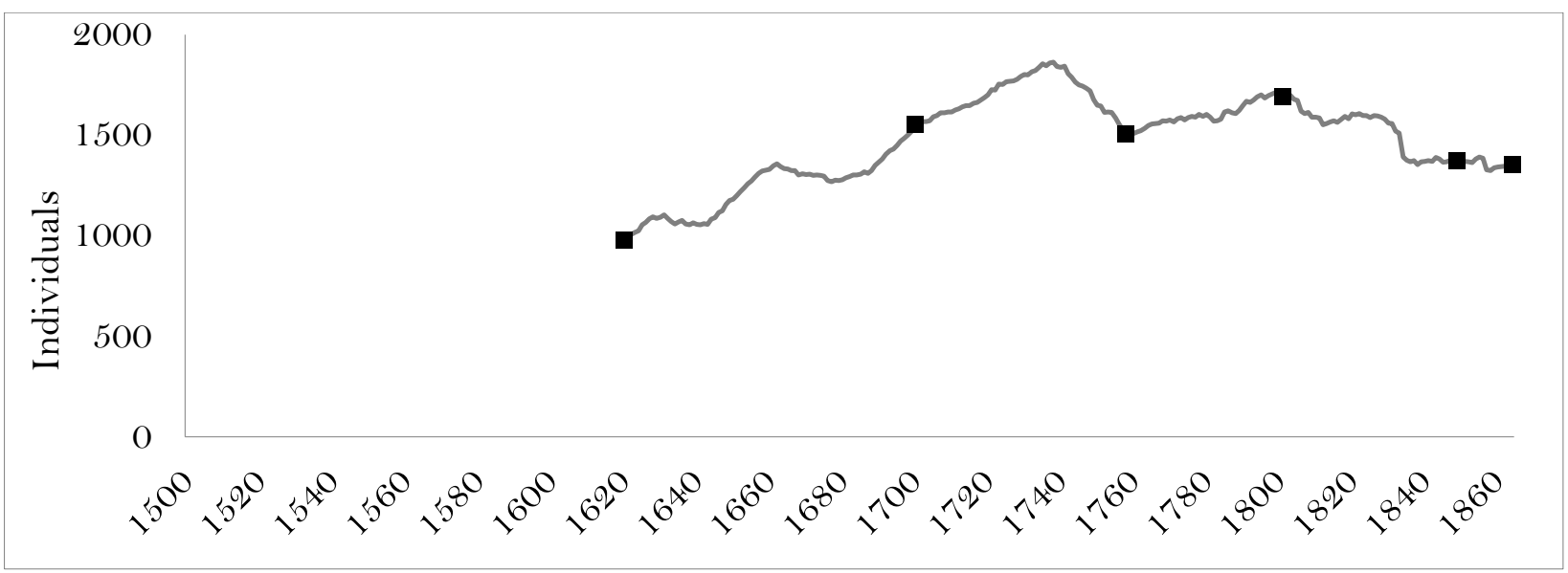

Figure E1. S. Pedro de Barcarena

E2. Nossa Senhora da Assunção de Cheleiros (1604-1864)

Location: The province of Estremadura and the archbishopric of Lisbon. A rural parish in the hinterland of Lisbon, in the municipality of Mafra. It now belongs to the district of Lisboa. Its first municipal charter was awarded in 1195 and renewed in 1516.

Population stock (number of inhabitants):

1530: 224 From the Numeramento da População, cited in Freire (1903-1916), vol. VI.

1700: 480 From Costa (1706-12).

1758: 400 From Arquivo Nacional da Torre do Tombo: Cheleiros, Lisboa Memórias paroquiais, vol. 11, nº 305, pp. 2123 a 2126.

1801: 489 Silveira (2001).

1849: 583 Silveira (2001).

1864: 698 Censo (1868). 
Source for births and deaths: Arquivo Distrital de Lisboa, Registos Paroquiais, Cheleiros: Baptismos - B1/B7; Óbitos - O1/O2; Mixtos M1/M3.

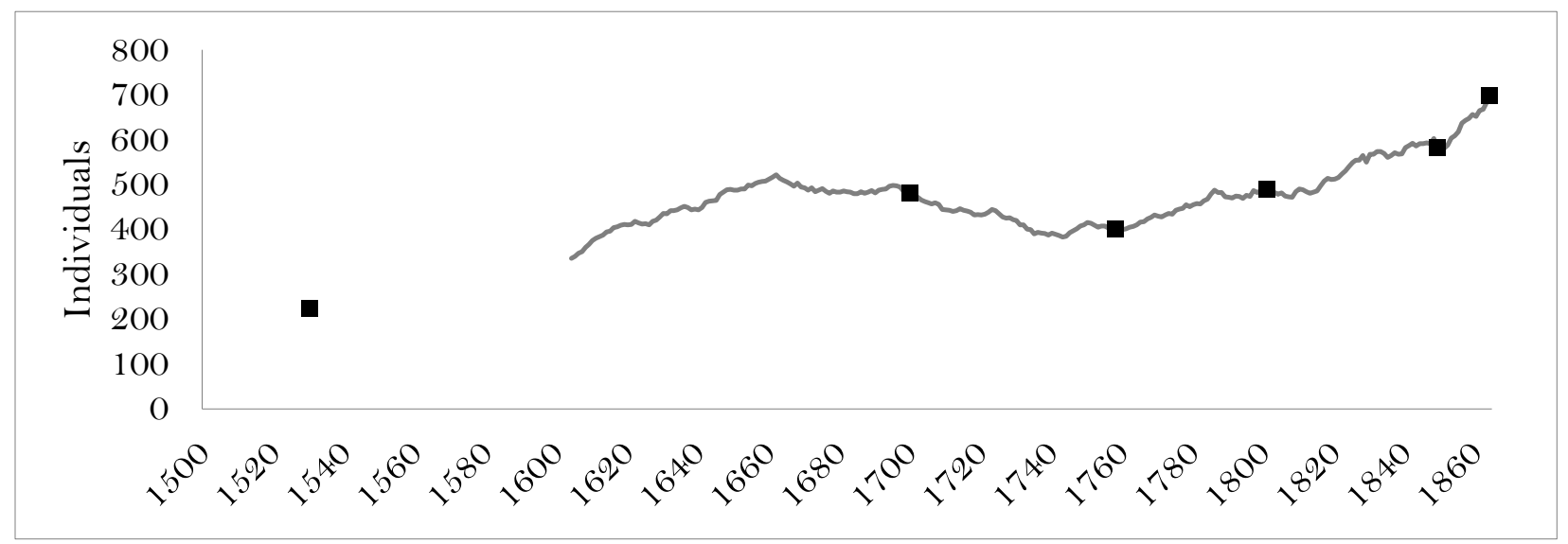

Figure E2. Nossa Senhora da Assunção de Cheleiros

E3. Nossa Senhora da Assunção de Enxara do Bispo (1530-1864)

Location: The province of Estremadura and the archbishopric of Lisbon. A rural parish in the hinterland of Lisbon, in the municipality of Mafra composed of two fractions - Enxara do Bipo and Enxara dos Cavaleiros. At present it belongs to the district of Lisboa. The parish church was reconstructed in 1519 on the remains of an earlier church which was originally a mosque and went back to the 11 th century.

Population stock (number of inhabitants):

1530: 168 From the Numeramento da População, cited in Freire (1903-1916), vol. VI.

1700: 340 (interpolated) This parish is in Costa (1706-12)

1758: 360 From Arquivo Nacional da Torre do Tombo: Enxara, Lisboa Memórias paroquiais, vol. 13, $\mathrm{n}^{\circ}$ 25, pp. 211 - 220.

1801: 1,393 Silveira (2001).

1849: 1,992 Silveira (2001).

1864: 1,636 Censo (1868). 
Source for births and deaths: Arquivo Distrital de Lisboa, Registos Paroquiais, Enxara do Bispo: Baptismos - B1/B10; Óbitos - O1/O6; Mixtos - M1/M6.

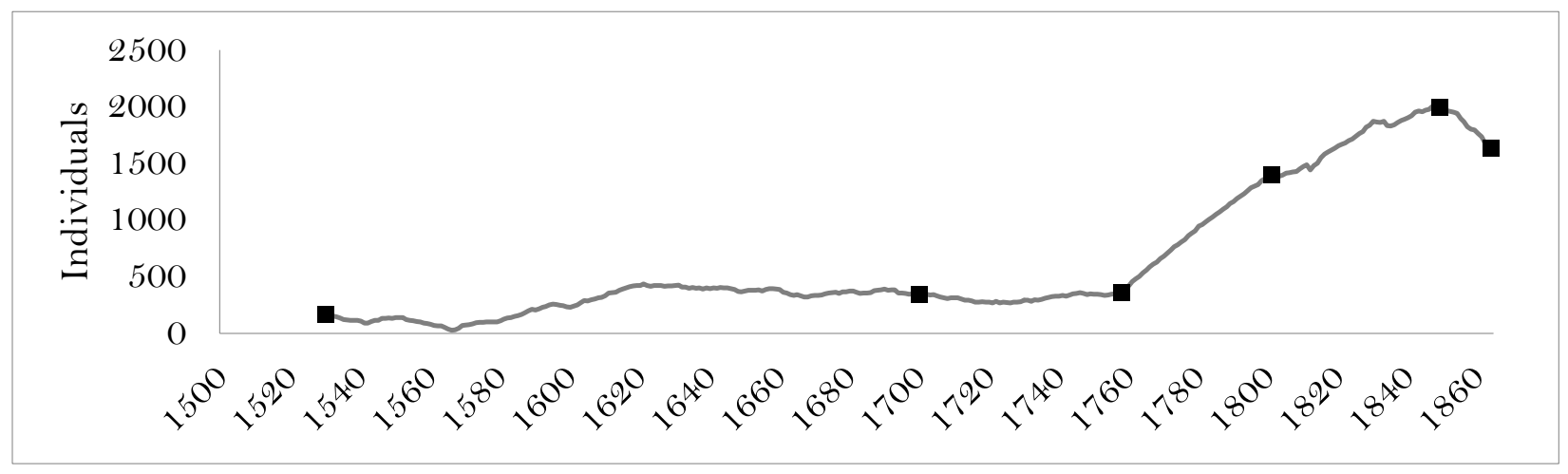

Figure E3. Nossa Senhora da Assunção de Enxara do Bispo

E4. S. João da Lourinhã (1530-1864)

Location: The province of Estremadura and the archbishopric of Lisbon. A rural parish in the hinterland of Lisbon, one of the most prosperous of the region, near the town of Torres Vedras. At present it belongs to the district of Lisboa. Lourinhã received a municipal charter in 1160, from the first king of Portugal.

Population stock (number of inhabitants):

1530: 520 From the Numeramento da População cited in Freire (1903-1916), vol. VI.

1700: 800 From Costa (1706-12).

1758: 1,940 From Arquivo Nacional da Torre do Tombo: Lourinhã, Lisboa - Memórias paroquiais, vol. 42, $\mathrm{n}^{\circ}$ 148, p. 78.

1801: 2,293 Silveira (2001).

1849: 2,571 Silveira (2001).

1864: 3,302 Censo (1868). 
Source for births and deaths: Arquivo Distrital de Lisboa, Registos

Paroquiais, Lourinhã: Baptismos - B1/B28; Óbitos - O1/O18; Mixtos M1/M9.

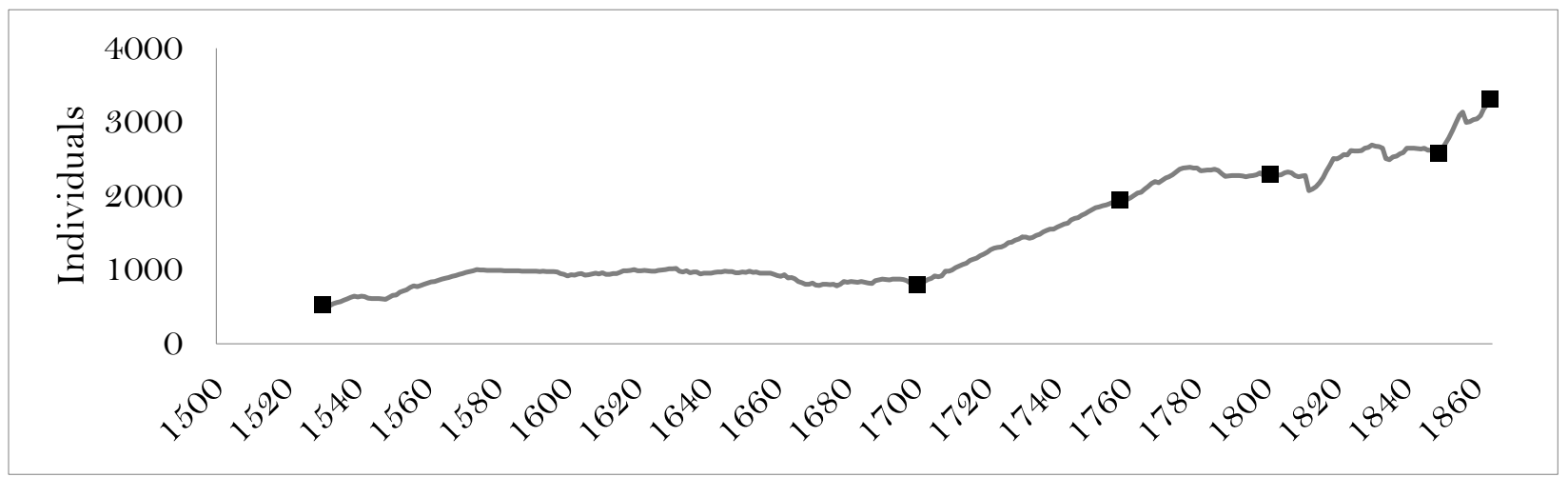

Figure E4. S. João da Lourinhã

E5. Nossa Senhora das Virtudes da Ventosa (1558-1835)

Location: The province of Estremadura and the archbishopric of Lisboa. A rural parish close to the city of Alenquer, it belongs at present to the district of Lisboa. The parish existed already in the 14th century and was probably founded after 1259 .

Population stock (number of inhabitants):

1530: 336 From the Numeramento da População cited in Freire (1903-1916), vol. VI

1700: 580 From Costa (1706-12).

1758: 957 in Arquivo Nacional da Torre do Tombo, Memórias paroquiais, Ventosa - Lisboa, vol. 39, nº 126, p. 717 - 720.

1801: 1,806 Silveira (2001).

1849: 1,817 Silveira (2001).

1864: 1,871 Censo (1868). 
Source for births and deaths: Arquivo Distrital de Lisboa, Registos Paroquiais de Lisboa, Ventosa (Alenquer): Baptismos - livros B1-B9; Óbitos - livros O1-O8; Caixas Mistas -Livros M1-M3.

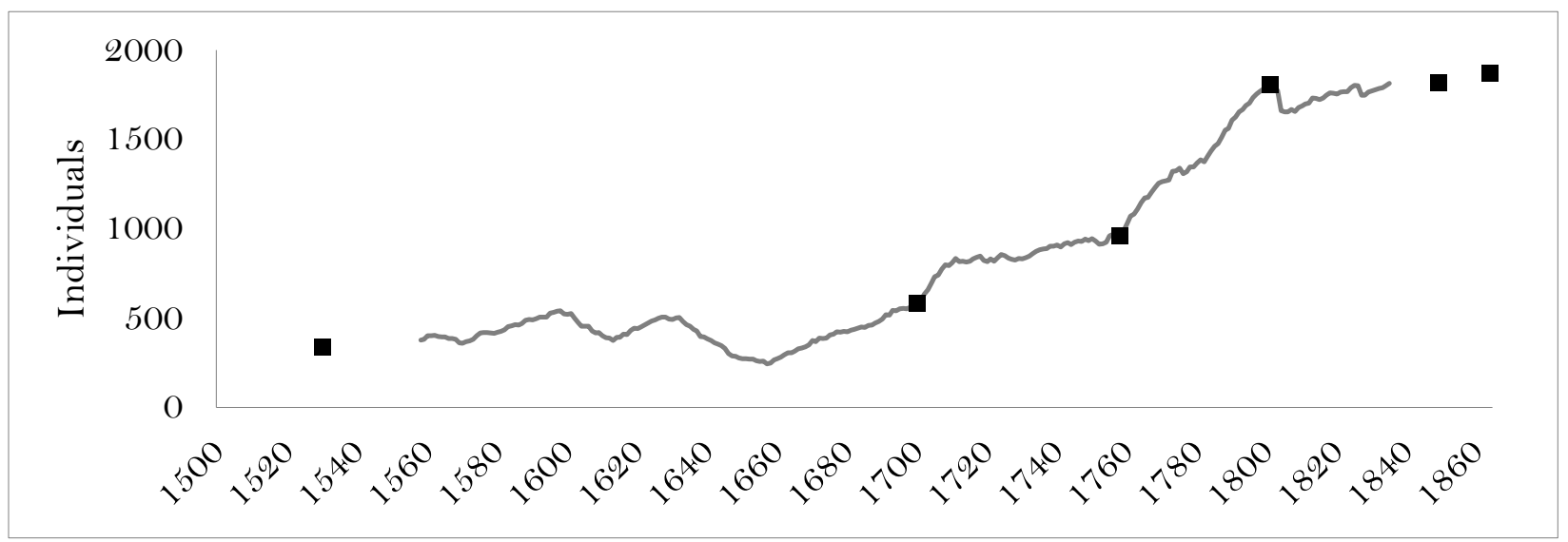

Figure E5. Nossa Senhora das Virtudes da Ventosa (1558-1835)

\section{F. Trás-os-Montes}

F1. Nossa Senhora da Oliveira da Cardanha (1574-1801)

Location: The province of Trás-os-Montes and the archbishopric of Bragança. A rural parish close to the town of Torre de Moncorvo, and belonging at present to the district of Bragança. Originally a pre-roman fortress town, the first written references to Cardanha are found in official documents of 1143 .

Population stock (number of inhabitants):

1530: 152 From the Numeramento da População, cited in Freire (1903-1916), vol. VII.

1700: 320 From Costa (1706-12).

1758: 332 Memórias Paroquiais, cited in Capela (2007).

1801: 318 Silveira (2001).

1849: 325 Silveira (2001).

1864: 489 Censo (1868). 
Source for births and deaths: Amorim (1980).

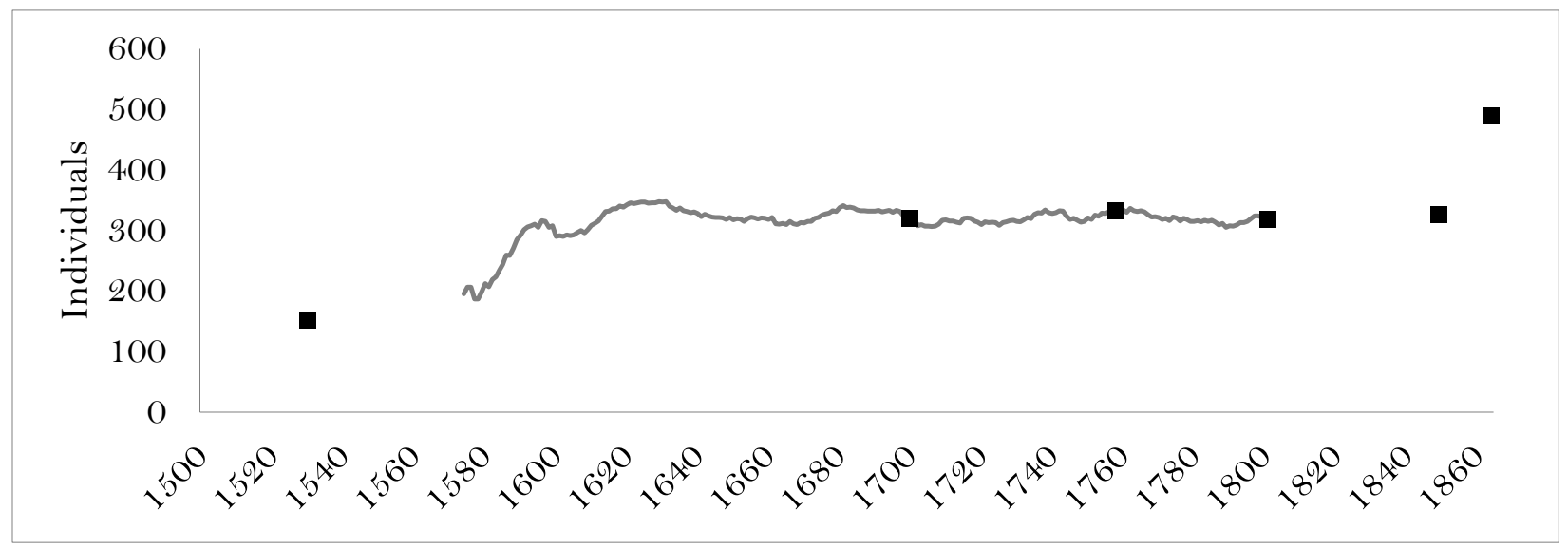

Figure F1. Nossa Senhora da Oliveira da Cardanha (1574-1801)

F2. Nossa Senhora da Assunção de Rebordãos (1610-1800)

Location: The province of Trás-os-Montes and the archbishopric of Bragança. A rural parish close to the town of Bragança, and belonging at present to the district of the same name. The municipal charter was conceded in 1208 and it received a castle soon after.

Population stock (number of inhabitants):

1530: 404 From the Numeramento da População, cited in Freire (1903-1916), vol. VII.

1700: 512 From Costa (1706-12).

1758: 460 Memórias Paroquiais, cited in Capela (2007).

1801: 397 Silveira (2001).

1849: 463 Silveira (2001).

1864: 638 Censo (1868).

Source for births and deaths: Amorim (1973). 


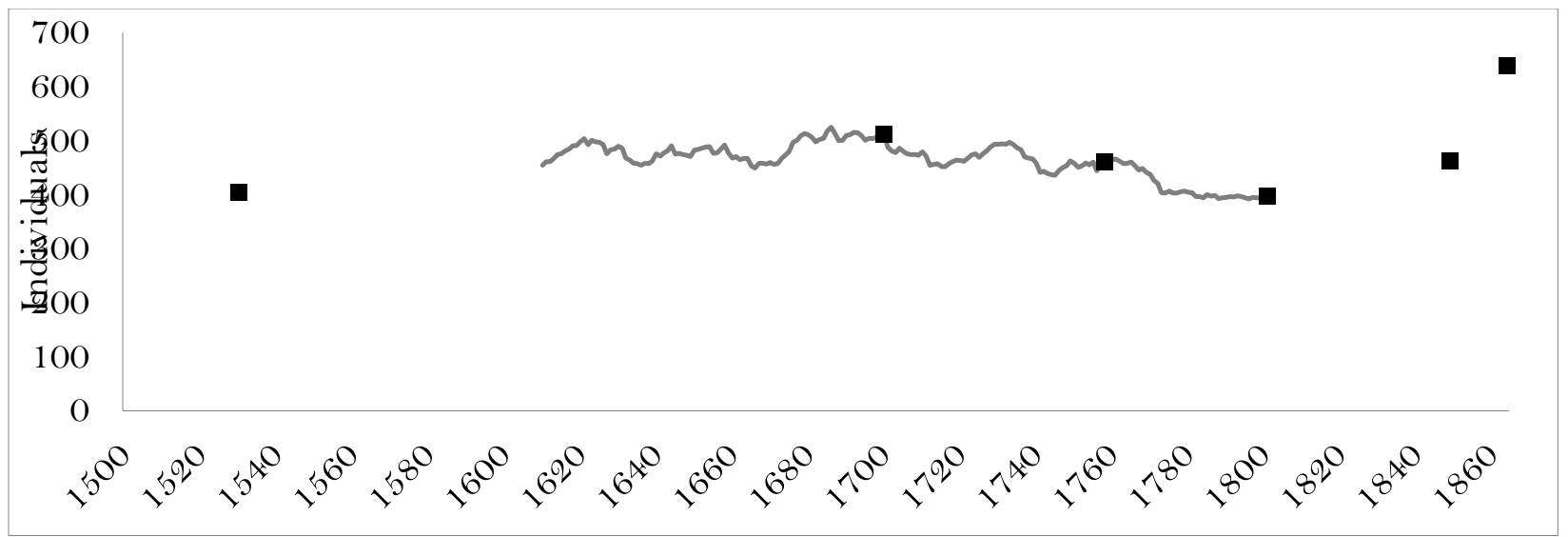

Figure F2. Nossa Senhora da Assunção de Rebordãos (1610-1800)

F3. S. Vicente de Castro Vicente (1691-1801)

Location: The province of Trás-os-Montes and the bishopric of Bragança. A rural parish close to the town of Mogadouro, it presently lies in the district of Bragança. Castro Vicente was originally a pre-roman fortress town and received its municipal charter in 1305 . The parish is a medieval foundation.

1530: 176 From the Numeramento da População, cited in Freire (1903-1916), vol. VI.

1700: 360 From Costa (1706-12).

1758: 384 From Memórias Paroquiais, cited in Capela (2007).

1801: 491 Silveira (2001).

1849: 589 Silveira (2001).

1864: 789 Censo (1868).

Source for births and deaths: Afonso (1974). 


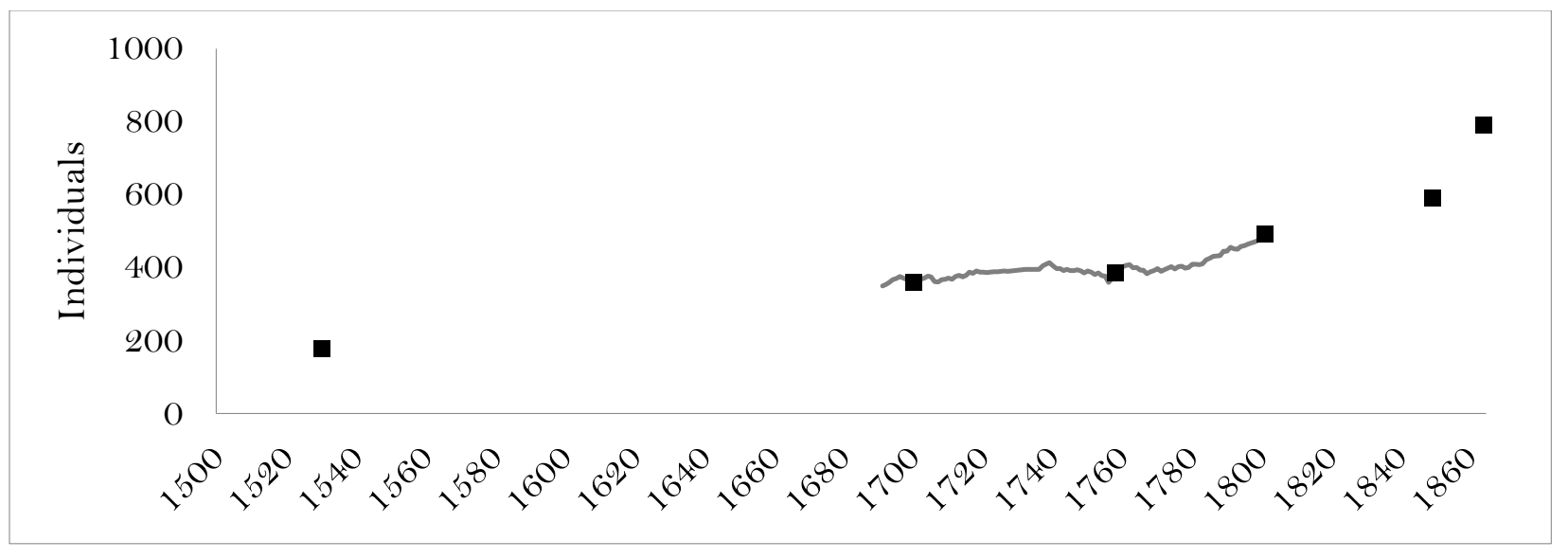

Figure F3. Castro Vicente 


\section{Additional tables (for online publication only)}

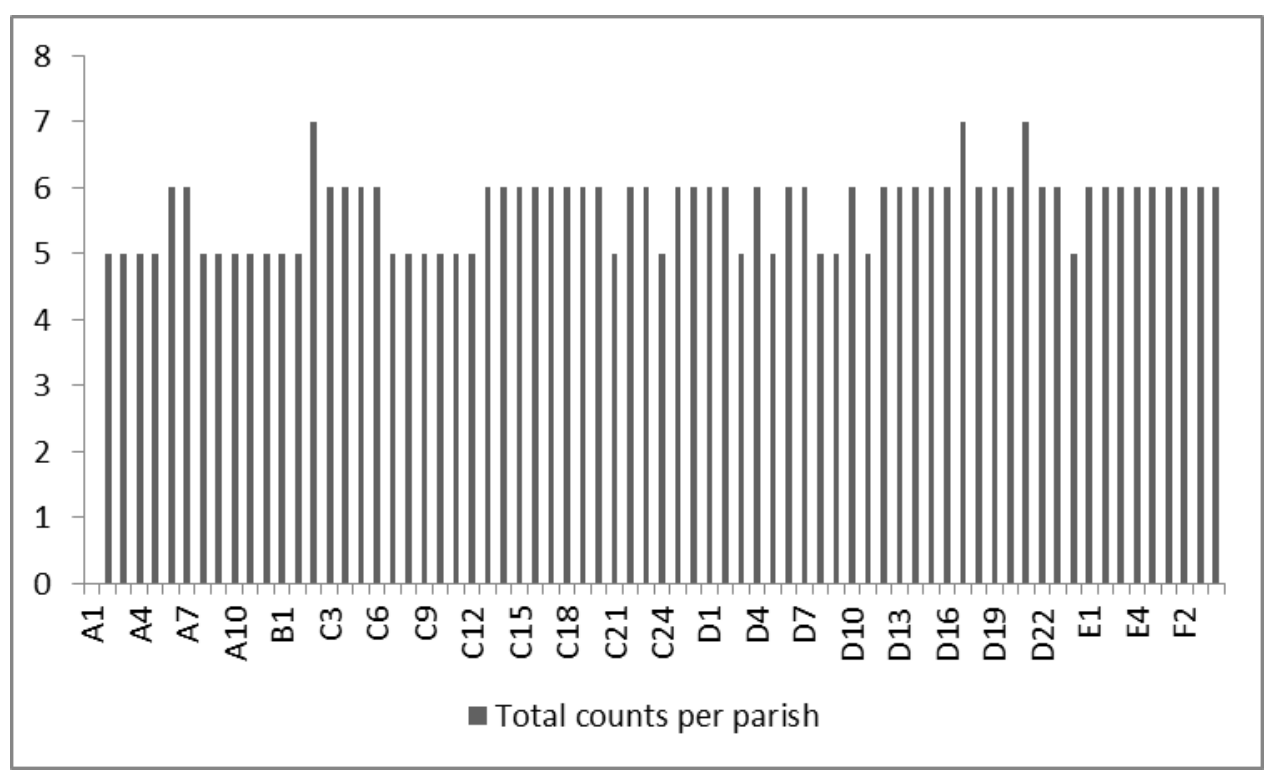

Figure A1. Total counts per parish.

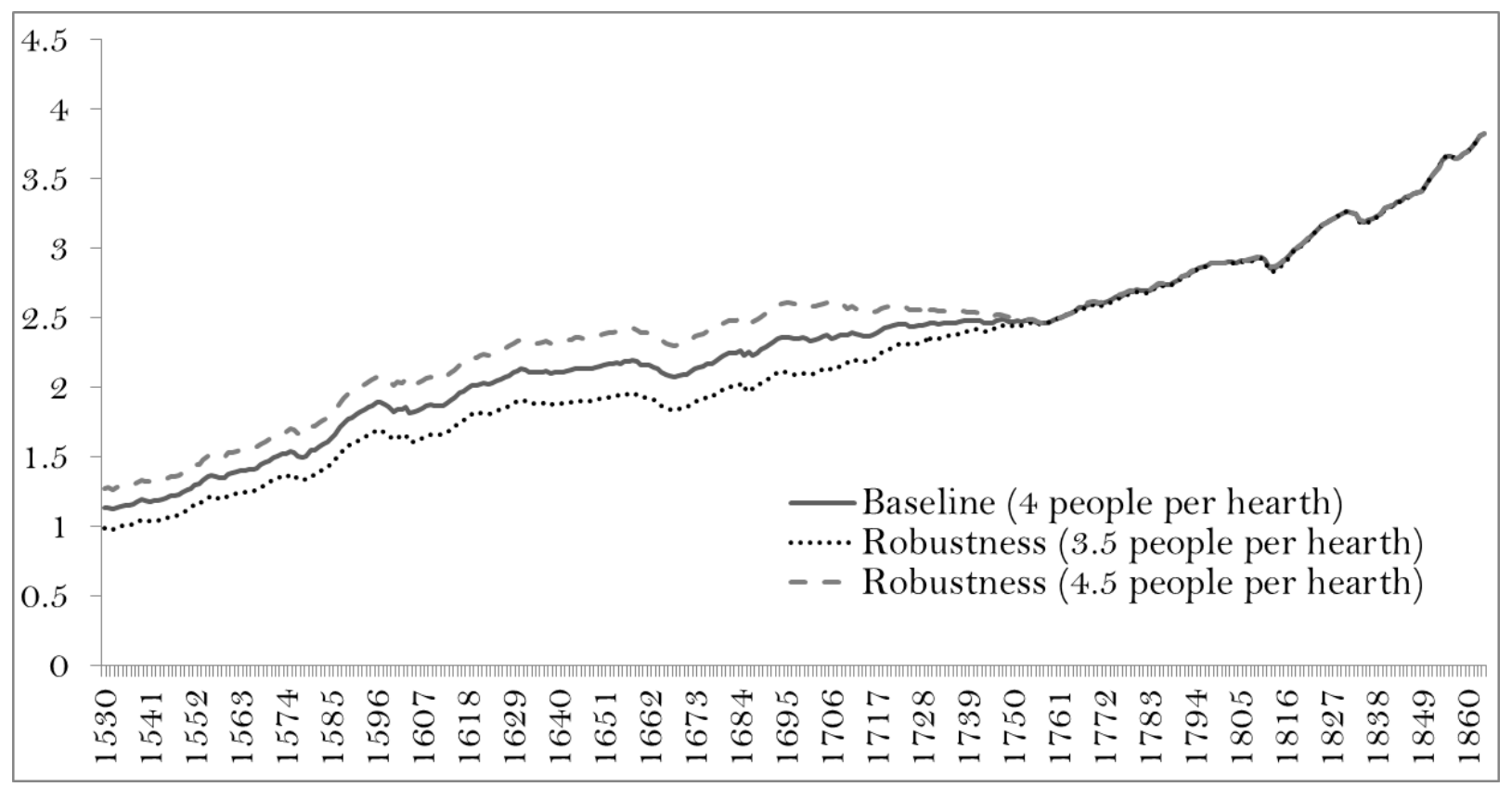

Figure A2. Total population under alternative assumptions about the hearths-to-individuals conversion factor. 
Place

Barcarena

Ventosa

Alvito S. Pedro

Alvito S. Pedro

Viseu city

Resende

Almeida

Urgeses

Oliveira do Castelo

Oliveira do Castelo
Period

1735-1864

1672-1864

1738-1821

1821-1859

1821-1833

1775-1792

$1700-1828$

1793-1819

$1741-1748$

40.0

39.3

461

400

25.5

31.8

432

37.6

40.5

32.6

1804-1811
Source

(\% of deaths)

Arquivo Distrital de

Lisboa, Registos
Oliveira (2002)

Oliveira (2002)

Oliveira (2002)

Amorim (1987)

Paroquiais, Barcarena:

Baptismos - B1 to B7;

Óbitos - O 1 to 4 .

Arquivo Distrital de Lisboa, Registos

Paroquiais de Lisboa, Ventosa (Alenquer):

Baptismos - livros B 1B9; Óbitos - livros O 1O8; Caixas Mistas Livros M1-M3

Miranda (1993)

Miranda (1993)

Amorim (1987)

Amorim (1987) 


\section{Costa}

Guimarães city

Guimarães city

S. Pedro de Poiares

Calvão

Bobadela

Bobadela

Lagares
1720-1760

1650-1719

1710-1760

1672-1787

1855-1857

1811-1866

1826-1866
30.8

46.4

46.6

40.9

35.6

Faustino (1998)

Arquivo Distrital de Lisboa: Bobadela - B1 to B3 (births), O 1 to O3 (deaths) and M1 to M2 (mixed registers).

Arquivo Distrital de Lisboa, Lagares, Registos Paroquiais: Baptismos, B 1-B4; Óbitos, O1-O8; Mixtos, M1-M2.

Table A1. Percentage of deaths under the age of 7 , by location. 
Parish 1530 1600* $1612^{*} \quad 1685^{*} \quad 1700 \quad 1720^{*} \quad 1758 \quad 1775^{*} \quad 1801 \quad 1849 \quad 1864$

Total counts

per parish

\begin{tabular}{|c|c|}
\hline $\mathrm{A} 1$ & \\
\hline $\mathrm{A}_{2}$ & \\
\hline A3 & \\
\hline $\mathrm{A}_{4}$ & \\
\hline A5 & \\
\hline A 6 & \\
\hline $\mathrm{A} 7$ & \\
\hline $\mathrm{A} 8$ & \\
\hline A9 & \\
\hline A 10 & \\
\hline A 11 & \\
\hline $\mathrm{A} 12$ & \\
\hline $\mathrm{B} 1$ & \\
\hline $\mathrm{C}_{1}$ & $\mathrm{X}$ \\
\hline
\end{tabular}

$\begin{array}{ll}\mathrm{X} & \mathrm{X} \\ \mathrm{X} & \mathrm{X} \\ \mathrm{X} & \mathrm{X} \\ \mathrm{X} & \mathrm{X} \\ \mathrm{X} & \mathrm{X} \\ \mathrm{X} & \mathrm{X} \\ \mathrm{X} & \mathrm{X} \\ \mathrm{X} & \mathrm{X} \\ \mathrm{X} & \mathrm{X} \\ \mathrm{X} & \mathrm{X} \\ \mathrm{X} & \mathrm{X} \\ \mathrm{X} & \mathrm{X} \\ & \mathrm{X} \\ & \\ & \end{array}$

$\begin{array}{lll}\mathrm{X} & \mathrm{X} & \mathrm{X} \\ \mathrm{X} & \mathrm{X} & \mathrm{X}\end{array}$

5

5

5

5

X $\quad$ X $\quad$ X

$\mathrm{X} \quad \mathrm{X} \quad \mathrm{X}$

6

$\begin{array}{lll}X & X & X\end{array}$

6

$\mathrm{X} \quad \mathrm{X}$

5

X $\quad$ X $\quad$ X

5

X $\mathrm{X} \quad \mathrm{X}$

5

X $\quad$ X $\quad$ X

5

X $\quad$ X $\quad$ X

5

$\begin{array}{lll}x & X & X\end{array}$

5

X $\mathrm{X} \quad \mathrm{X}$

5

$\begin{array}{lll}x & X\end{array}$

7 


\begin{tabular}{|c|c|c|c|c|c|c|c|c|c|c|c|}
\hline $\mathrm{C}_{2}$ & & & $\mathrm{X}$ & & $\mathrm{X}$ & & $\mathrm{X}$ & $\mathrm{X}$ & $\mathrm{A}$ & A & 6 \\
\hline C3 & & & $\mathrm{X}$ & & $\mathrm{X}$ & & $\mathrm{X}$ & $\mathrm{X}$ & $\mathrm{A}$ & A & 6 \\
\hline $\mathrm{C}_{4}$ & & & $\mathrm{X}$ & & $\mathrm{X}$ & & $\mathrm{X}$ & $\mathrm{X}$ & A & A & 6 \\
\hline $\mathrm{C} 5$ & & & $\mathrm{X}$ & & $\mathrm{X}$ & & $\mathrm{X}$ & $\mathrm{X}$ & $\mathrm{A}$ & A & 6 \\
\hline C6 & & $\mathrm{X}$ & & & & $\mathrm{X}$ & & $\mathrm{X}$ & $\mathrm{X}$ & $\mathrm{X}$ & 5 \\
\hline $\mathrm{C} 7$ & & $\mathrm{X}$ & & & & $\mathrm{X}$ & & $\mathrm{X}$ & $X$ & $\mathrm{X}$ & 5 \\
\hline $\mathrm{C} 8$ & & $\mathrm{X}$ & & & & $\mathrm{X}$ & & $\mathrm{X}$ & $\mathrm{A}$ & $\mathrm{X}$ & 5 \\
\hline C9 & & $X$ & & & & $\mathrm{X}$ & & $\mathrm{X}$ & $\mathrm{X}$ & $\mathrm{X}$ & 5 \\
\hline $\mathrm{C} 10$ & & X & & & & $\mathrm{X}$ & & $\mathrm{X}$ & X & A & 5 \\
\hline $\mathrm{C} 11$ & & $\mathrm{X}$ & & & & $\mathrm{X}$ & & $\mathrm{X}$ & $X$ & A & 5 \\
\hline $\mathrm{C} 12$ & $\mathrm{X}$ & & & $\mathrm{X}$ & & $\mathrm{X}$ & & $\mathrm{X}$ & $\mathrm{X}$ & $\mathrm{X}$ & 6 \\
\hline $\mathrm{C} 13$ & $\mathrm{X}$ & & & $\mathrm{X}$ & & $\mathrm{X}$ & & $\mathrm{X}$ & $\mathrm{X}$ & $\mathrm{X}$ & 6 \\
\hline $\mathrm{C} 14$ & $\mathrm{X}$ & & & $\mathrm{X}$ & & $\mathrm{X}$ & & $\mathrm{X}$ & $\mathrm{X}$ & $\mathrm{X}$ & 6 \\
\hline $\mathrm{C} 15$ & $\mathrm{X}$ & & & $\mathrm{X}$ & & $\mathrm{X}$ & & $\mathrm{X}$ & $\mathrm{X}$ & $\mathrm{X}$ & 6 \\
\hline $\mathrm{C} 16$ & $\mathrm{X}$ & & & $\mathrm{X}$ & & $\mathrm{X}$ & & $\mathrm{X}$ & $\mathrm{X}$ & $\mathrm{X}$ & 6 \\
\hline $\mathrm{C}_{17}$ & $X$ & & & $\mathrm{X}$ & & $\mathrm{X}$ & & $\mathrm{X}$ & $X$ & $\mathrm{X}$ & 6 \\
\hline
\end{tabular}




\begin{tabular}{|c|c|c|c|c|c|c|}
\hline $\mathrm{C} 18$ & $\mathrm{X}$ & $\mathrm{X}$ & $\mathrm{X}$ & $\mathrm{X}$ & $\mathrm{X}$ & $\mathrm{X}$ \\
\hline C19 & $\mathrm{X}$ & $\mathrm{X}$ & $\mathrm{X}$ & $\mathrm{X}$ & $\mathrm{X}$ & $\mathrm{X}$ \\
\hline $\mathrm{C} 20$ & $\mathrm{X}$ & $\mathrm{X}$ & & $\mathrm{X}$ & $\mathrm{X}$ & $\mathrm{X}$ \\
\hline $\mathrm{C} 21$ & $\mathrm{X}$ & $\mathrm{X}$ & $\mathrm{X}$ & $\mathrm{X}$ & $\mathrm{X}$ & $\mathrm{X}$ \\
\hline $\mathrm{C}_{22}$ & $\mathrm{X}$ & $X$ & $\mathrm{X}$ & $\mathrm{X}$ & $\mathrm{X}$ & $\mathrm{X}$ \\
\hline $\mathrm{C} 23$ & $\mathrm{X}$ & $\mathrm{X}$ & & $\mathrm{X}$ & $\mathrm{X}$ & $\mathrm{X}$ \\
\hline $\mathrm{C} 24$ & $\mathrm{X}$ & $\mathrm{X}$ & $\mathrm{X}$ & $\mathrm{X}$ & $\mathrm{X}$ & $\mathrm{X}$ \\
\hline $\mathrm{C} 25$ & $\mathrm{X}$ & $\mathrm{X}$ & $\mathrm{X}$ & $\mathrm{X}$ & $\mathrm{X}$ & $\mathrm{X}$ \\
\hline C26 & $\mathrm{X}$ & $X$ & $\mathrm{X}$ & $\mathrm{X}$ & $\mathrm{X}$ & $\mathrm{X}$ \\
\hline D1 & $\mathrm{X}$ & $\mathrm{X}$ & $\mathrm{X}$ & $\mathrm{X}$ & $\mathrm{X}$ & $\mathrm{X}$ \\
\hline $\mathrm{D} 2$ & & $X$ & $\mathrm{X}$ & $\mathrm{X}$ & $\mathrm{X}$ & $\mathrm{X}$ \\
\hline D3 & $\mathrm{X}$ & $\mathrm{X}$ & $\mathrm{X}$ & $\mathrm{X}$ & $\mathrm{X}$ & $\mathrm{X}$ \\
\hline $\mathrm{D} 4$ & & $X$ & $\mathrm{X}$ & $\mathrm{X}$ & $\mathrm{X}$ & $\mathrm{X}$ \\
\hline D5 & $\mathrm{X}$ & $\mathrm{X}$ & $\mathrm{X}$ & $\mathrm{X}$ & $\mathrm{X}$ & $\mathrm{X}$ \\
\hline D6 & $\mathrm{X}$ & $\mathrm{X}$ & $X$ & $\mathrm{X}$ & $\mathrm{X}$ & $X$ \\
\hline D7 & & & $\mathrm{X}$ & $\mathrm{X}$ & $\mathrm{X}$ & $\mathrm{X}$ \\
\hline
\end{tabular}




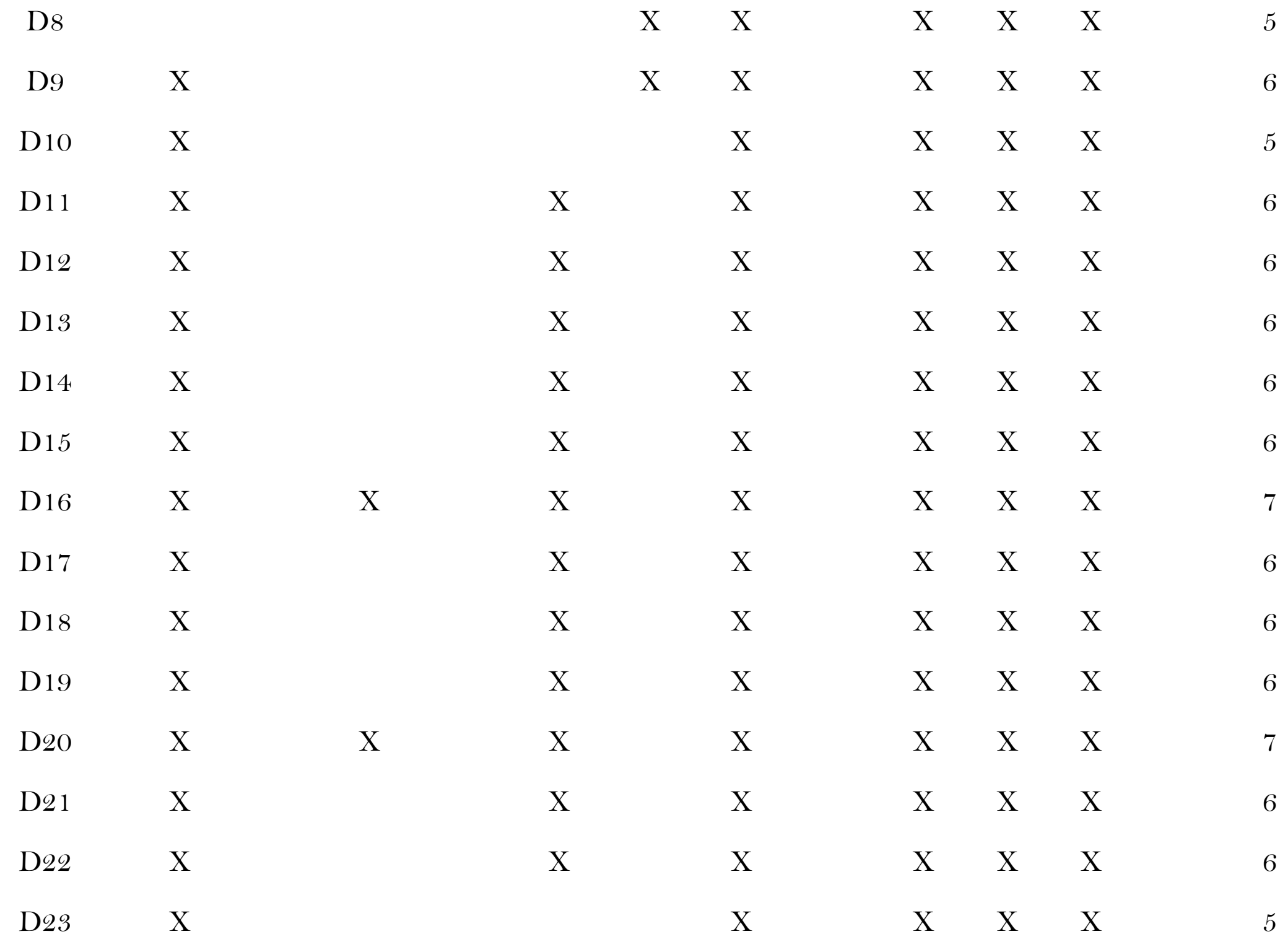




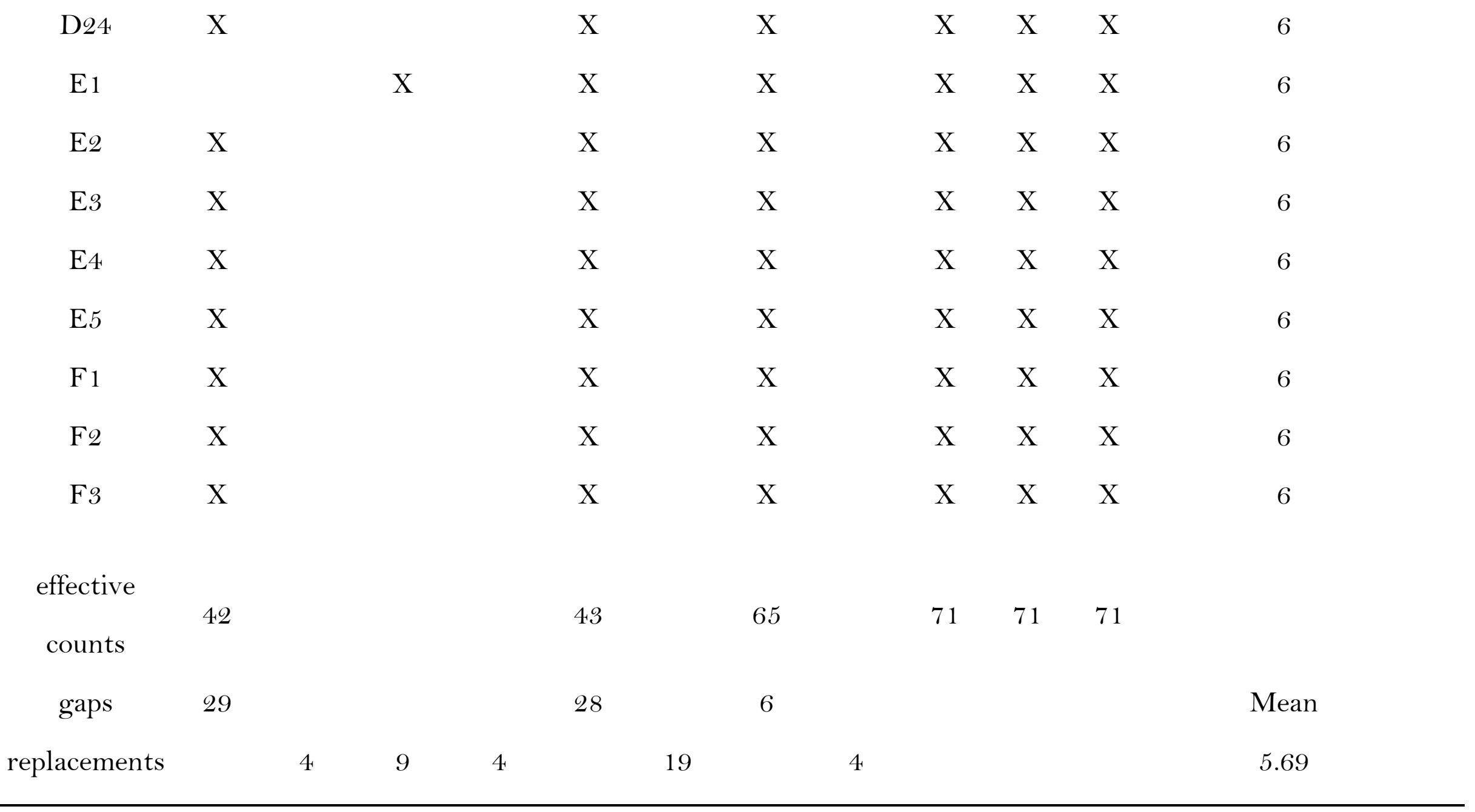

Table A2 Gaps and counts in all population counts. * refers to population counts used as replacements. 



\begin{tabular}{|c|c|c|}
\hline \multicolumn{2}{|c|}{ Alentejo } & \multirow[b]{2}{*}{ C24. N. S. da Graça de Fragosela (Viseu) } \\
\hline (1) & A1. S. Marcos da Abóbada (Évora) & \\
\hline (2) & A2. S. Miguel de Machede (Évora) & (3) C25. Vila Chã de Sá (Viseu) \\
\hline (3) & A3. S. Matias (Évora) & 39 C26. Mundão (Viseu) \\
\hline (4) & A4. S. Vicente do Pigeiro (Évora) & Entre-Douro-e-Minho \\
\hline 5 & A5. S. Maria (Évora Monte) & (40) D1. S. Martinho de Alvito S. Pedro e Ginzo (Braga) \\
\hline 6 & A6. S. Pedro (Évora Monte) & (41) D2. Santiago de Esporões (Braga) \\
\hline (7) & A7. Boa Fé (Évora) & (4) D3. Santa Eulália de Fermentões (Braga) \\
\hline 8 & A8. Divor (Évora) & (43) D4. Santa Marinha da Costa \\
\hline (9) & A9. S. Brás do Regedouro (Évora) & (4) D5. S. Romão de Mesão Frio \\
\hline 10 & A10. Torre de Coelheiros (Évora) & (45) D6. Urgeses (Guimarães) \\
\hline (11) & A11. Monte do Trigo (Évora) & (46) D7. Oliveira dos Castelo (Guimarães) \\
\hline (1) & A12. N.S. Consolação Igrejinha (Évora) & (47) D8. S. Sebastião (Guimarães) \\
\hline \multicolumn{2}{|c|}{ Algarve } & (48) D9. S.Paio (Guimarães) \\
\hline (B) & B1. N.S. da Conceição de Tavira (Faro) & (49) D10. S. Miguel do Castelo (Guimarães) \\
\hline Beira & & (5) D11. S. Miguel de Creixomil \\
\hline (14) & C1. São Tiago de Almalaguez (Coimbra) & (51) D12. Azurem (Guimarães) \\
\hline 15 & C2. Vera Cruz (Aveiro) & (52) D13. S. Marinha de Gontinhães \\
\hline 16 & C3. S. Miguel (Aveiro) & 53 D14. Santiago de Romarigaes \\
\hline (17) & C4. N.S da Apresentação (Aveiro) & 54 D15. S. João Baptista de Canelas \\
\hline 18 & C5. Espirito Santo (Aveiro) & (5) D16. S. João Batista de Vila do Conde \\
\hline (19) & C6. S. Bartolomeu (Coimbra) & 56 D17. S. João das Caldas \\
\hline (20) & C7. S. João da Santa Cruz (Coimbra) & (5) D18. S. Martinho de Ávidos \\
\hline (21) & C8. Sé (Coimbra) & (5) D19. S. Pedro de Esmeriz \\
\hline (2) & C9. S. Tiago (Coimbra) & 59 D20. S. Tiago de Bougado \\
\hline (2) & C10. Santa Justa (Coimbra) & (6) D21. Santiago de Lordelo (Braga) \\
\hline 24 & C11. S Pedro (Coimbra) & 61) D22. Santiago de Ronfe (Braga) \\
\hline (2) & C12. N. S. da Graça Bobadela (Coimbra) & (6) D23. Oliveira do Douro \\
\hline 6 & C13. N.S. Conceição Lagares (Coimbra) & 63 D24. Póvoa de Varzim \\
\hline (2) & C14. Eixo e Oliveirinha (Aveiro) & Estremadura \\
\hline (8) & C15. S. Martinho da Árvore (Coimbra) & 64) E1. Barcarena \\
\hline (2) & C16. S. João Baptista de Lourosa (Viseu) & (6) E2. Cheleiros \\
\hline (3) & C17. Santa Maria de Tondela (Viseu) & 66 E3. Enxara do Bispo \\
\hline (31) & C18. S. Pedro do Sul (Viseu) & (6) E4. Lourinhä \\
\hline (32) & C19. S. Julião de Mangualde (Viseu) & (B) E5. Ventosa \\
\hline 33 & C20. S. Maria de Vouzela (Viseu) & Trás-os-Montes \\
\hline 34) & C21. N.S. da Conceição de Nelas (Viseu) & 69 F1. Cardanha \\
\hline (3) & C22. S. Maria de Canas Sabugosa (Viseu) & (7) F2. Rebordãos \\
\hline 36 & C23. S. Isidoro dos Santos Evos (Viseu) & (71) F3. S. Pedro de Castro Vicente (Bragança) \\
\hline
\end{tabular}

Table A3. Full list of parishes 


\section{References Appendix}

\section{Primary sources}

Arquivo da Universidade de Coimbra, Registos Paroquiais, Almalaguês: Baptismos - Livros 15; Óbitos - Livro 1; Mistos - Livro1.

Arquivo Distrital de Lisboa, Registos Paroquiais, Barcarena: Baptismos - B1 to B7; ; Óbitos O1 to 4 .

Arquivo Distrital de Lisboa: Bobadela: Baptismos - B1 to B3; Óbitos - O1 to O3; and Mistos $\mathrm{M} 1$ to $\mathrm{M} 2$.

Arquivo Distrital de Lisboa, Registos Paroquiais, Cheleiros: Baptismos - B1/B7; Óbitos $\mathrm{O} 1 / \mathrm{O} 2$; Mistos - M1/M3.

Arquivo Distrital de Lisboa, Registos Paroquiais, Enxara do Bispo: Baptismos - B1/B10; Óbitos-O1/O6; Mixtos-M1/M6.

Arquivo Distrital de Lisboa, Lagares, Registos Paroquiais: Baptismos - B1/B4; Óbitos $\mathrm{O} 1 / \mathrm{O} 8 ;$ Mistos - M1/M2.

Arquivo Distrital de Lisboa, Registos Paroquiais, Lourinhã: Baptismos - B1/B28; Óbitos O1/O18; Mixtos - M1/M9.

Arquivo Distrital de Lisboa, Registos Paroquiais de Lisboa, Ventosa (Alenquer): Baptismos livros B1-B9; Óbitos - livros O1-O8; Caixas Mistas -Livros M1-M3.

Arquivo Municipal de Vila do Conde, manuscript lists of births and deaths for Vila do Conde obtained by the CEDOPORMAR group (org. Cristina Giesteira).

Arquivo Municipal de Vila do Conde, manuscript lists of births and deaths for Povoa de Varzim obtained by the CEDOPORMAR group (Cristina Giesteira org.).

Arquivo Nacional da Torre do Tombo (ANTT), Barcarena/ PT/ADLSB/PRQ/POER02: registo de nascimentos - 001; registo de óbitos -003.

Arquivo Nacional da Torre do Tombo: Barcarena, Lisboa - Memórias paroquiais, vol. 6, nº 31 , p. 203 a 204.

Arquivo Nacional da Torre do Tombo: Cheleiros, Lisboa - Memórias paroquiais, vol. 11, $\mathrm{n}^{\circ}$ 305, p. 2123 a 2126.

Arquivo Nacional da Torre do Tombo: Enxara, Lisboa - Memórias paroquiais, vol. 13, $\mathrm{n}^{\mathrm{o}}$ (E) 25, p. 211 a 220.

From Arquivo Nacional da Torre do Tombo: Lourinhã, Lisboa - Memórias paroquiais, vol. 42, $\mathrm{n}^{\circ} 148$, p. 78.

Arquivo Nacional da Torre do Tombo, Memórias paroquiais, Ventosa - Lisboa, vol. 39, $\mathrm{n}^{\mathrm{o}}$ 126, p. 717 a 720 . 


\section{Secondary sources}

Afonso, Berta das Dores (1974). Castro Vicente e a sua População de 1691 a 1799. Licenciate dissertation, University of Coimbra.

Alves, Jorge (1986). S. Tiago do Bougado, 1650-1849. Master's dissertations, Faculdade de Letras, University of Porto.

Amorim, Inês (1996). Aveiro e a sua provedoria no séc. XVIII: 1690-1814: Estudo económico de um espaço histórico. Ph.D. dissertation, Universidade of Porto.

Amorim, Maria Norberta (1987). Guimarães 1580-1819: Estudo demográfico (Lisboa: Instituto Nacional de Investigação Científica).

Amorim, Maria Norberta (1980). Método de exploração dos Livros de Registo Paroquiais de Cardanha e a sua população de 1573 a 1800. (Lisboa: INE).

Amorim, Maria Norberta (1973). Rebordãos e a sua população nos sécs. XVII e XVIII: estudo demográfico (Lisboa: Imprensa Nacional-Casa da Moeda).

Capela, José Viriato (2011). As freguesias dos distritos de Aveiro e Coimbra nas memórias paroquiais de 1758: Memórias, história e património (Braga: Minhografe).

Capela, José Viriato (2010). As freguesias do distrito de Viseu nas memórias paroquiais de 1758: Memórias, história e património (Braga: Minhografe).

Capela, José Viriato (2009). As freguesias do distrito do Porto nas memórias paroquiais de 1758: Memórias, história e património (Braga: Barbosa \& Xavier).

Capela, José Viriato (2007) As freguesias do distrito de Bragança nas memórias paroquiais de 1758: Memórias, história e património (Braga: Barbosa \& Xavier).

Capela, José Viriato (2003). As freguesias do distrito de Braga nas memórias paroquiais de 1758: Memórias, história e património (Braga: Barbosa \& Xavier).

Censo no $1^{\circ}$ de Janeiro de 1864. Estatistica. População (1868). (Lisboa: Imprensa Nacional).

Colaço, João Telo de Magalhães (1934). Cadastro da População do Reino (1527). Actas das Comarcas dantre Tejo e Odiana e da Beira, Revista da Faculdade de Direito da Universidade de Lisboa, II, pp. 28- 243.

Costa, António Carvalho da (1706-1712). Corografia Portuguesa e Descrição Topográfica do Famoso Reino de Portugal com as Notícias das Fundações das Cidades, Villas e Lugares.... (Lisboa: Oficina de Valentim da Costa Deslandes, 3 vols.).

Costa, Francisco Barbosa da (1994). S. João Baptista de Canelas. Uma comunidade rural da Terra de Santa Maria: Um estudo demográfico, 1588-1808. (Vila Nova de Gaia: Afons'eiro Edições).

Ferreira, Antero (2001). Sistema de aquisição de dados para a reconstituição de paróquias: a reprodução social em S. João das Caldas (1600-1910). Master's dissertation, University of Minho. 
Ferreira, Francisco Messias (2001). A antiga freguesia de Eixo e Oliveirinha (1666-1900) (Aveiro: Câmara Municipal de Aveiro).

Freire, Anselmo Braamcamp (ed.) (1903-1916). Cadastro da População do Reino (1527-1532), Archivo Historico Portuguez (Facsimile reproduction 2001) (Santarem: 2001), vols. III, IV, VI and VII.

Gaivão, Maria do Carmo (1974). A freguesia de S. Martinho da Árvore de 1616 a 1685. Estudo demográfico. Licenciate dissertation, Faculdade de Letras, University of Coimbra.

Janeiro, José Adriano (1997). Gerações sacrificadas: A população e a sociedade de S. Tiago de Lordelo, séculos XVII a XX. Master's dissertation. University of Minho.

Leite, Odete (1999), S. Martinho de Ávidos: Comunidade rural do vale do Ave (demografia e sociedade (1599-1995). Master's dissertation, University of Minho.

Miranda, Fernando (1993). Estudo demográfico de Alvito S. Pedro e anexa, 1567-1989. (Barcelos: Junta de Freguesia de Alvito S. Pedro).

Oliveira, António de (1972). A vida económica e social de Coimbra de 1537 a 1640 (Coimbra: Instituto de Alta Cultura, 2 vols).

Oliveira, João Nunes de (1990). A produção agrícola de Viseu entre 1550 e 1700 (Viseu: Câmara Municipal de Viseu).

Oliveira, João Nunes de (2002). A Beira Alta de 1700 a 1840: Gentes e subsistências (Viseu: Palimage).

Oliveira, Nicolau de (1620). Livro das Grandezas de Lisboa (Lisboa: Jorge Rodriguez).

Pinto, José Antonio de Faria (1996) Estudo demográfico de uma paróquia algarvia: Conceição de Tavira (séculos XVIII-XIX), Master's dissertation, ISCTE, Lisboa.

Polónia, Amélia (1999). Vila do Conde, um porto nortenho na expansão quinhentista. Ph.D. dissertation, University of Porto, 2 vols.

Rego, Maria Aurora (2012). De Santa Marinha de Gontinhães a Vila Praia de Âncora (16241924). Demografia, sociedade e família. Ph.D. dissertation, University of Minho.

Santos, Carlota (1999). Santiago de Romarigães, comunidade rural do Alto Minho: Sociedade e demografia (1640-1872). (Paredes de Coura: Câmara Municipal de Paredes de Coura).

Santos, Rui (2003). Sociogénese do latifundismo moderno: Mercados, crises e mudança social na região de Évora, séculos XVII a XIX. (Lisboa: Banco de Portugal).

Scott, Ana Sílvia (1999). Famílias, formas de união e reprodução social no Noroeste português (Séculos XVIII e XIX). (Guimarães: NEPS - Universidade do Minho).

Silveira, Luís Nuno Espinha da et al. (ed.) (2001). Os recenseamentos da população portuguesa de 1801 e 1849. (Lisboa: INE).

Soares, Franquelim (1987). Monografia de S. Pedro de Esmeriz (Vila Nova de Famalicão: Câmara Municipal de S. Pedro de Esmeriz). 